\title{
ADITIVOS QUÍMICOS E MICROBIANOS NO CONTROLE DE PERDAS E NA QUALIDADE DE SILAGEM DE \\ CANA-DE-AÇÚCAR (Saccharum officinarum L.)
}

\section{ANDRÉ DE FARIA PEDROSO}

Tese apresentada à Escola Superior de Agricultura "Luiz de Queiroz", Universidade de São Paulo, para obtenção do título de Doutor em Agronomia, Área de Concentração: Ciência Animal e Pastagens.

PIRACICABA

Estado de São Paulo - Brasil Julho - 2003 


\section{ADITIVOS QUÍMICOS E MICROBIANOS NO CONTROLE DE PERDAS E NA QUALIDADE DE SILAGEM DE \\ CANA-DE-AÇÚCAR (Saccharum officinarum L.)}

\section{ANDRÉ DE FARIA PEDROSO}

Engenheiro Agrônomo

Orientador: Prof. Dr. LUIZ GUSTAVO NUSSIO

Tese apresentada à Escola Superior de Agricultura "Luiz de Queiroz", Universidade de São Paulo, para obtenção do título de Doutor em Agronomia, Área de Concentração: Ciência Animal e Pastagens.

PIRACICABA

Estado de São Paulo - Brasil

Julho - 2003 
Dados Internacionais de Catalogação na Publicação (CIP)
DIVISÃO DE BIBLIOTECA E DOCUMENTAÇÃO - ESALQ/USP

Pedroso, André de Faria

Aditivos químic ose mic robianos no controle de perdase na

qua lida de de silagem de cana-de-açúcar (Saccha rum offic ina rum L) /

André de Faria Pedroso. - - Piracic aba, 2003.

$120 \mathrm{p}$.

Tese (doutorado) - Escola Superior de Agricultura Luiz de Queiroz, 2003.

Bibliografia.

1. Aditivo a limentar para animal 2. Cana-de-açúcar 3. Crescimento a nimal 4. Fermentação 5. Silagem 6. Va lor nutritivo I.Título

CDD 636.08552

"Permitida a cópia total ou parcial deste documento, desde que citada a fonte - $\mathrm{O}$ autor" 
Dedico este trabalho a os meus pa is Asdruba I e Rosalia

À minha querida esposa, Maria Antonia, e a os n ossos fil hos Luca s e Ga briel ofereço. 


\section{AGRADECIMENTOS}

Ao Prof. Dr. Luiz Gustavo Nussio, pela firme orientação, pelos valiosos ensinamentos e pela grande amizade.

Aos colegas de curso, Lucas, Daniele, Solidete, Maity, Patrick, José Leonardo, Marta, Fábio, Maurício e Rodrigo, pela ajuda na condução dos trabalhos, pelo apoio e amizade.

Aos professores doutores Jorge Horii, Flávio César A. Tavares e Irineu Umberto Paker pela colaboração nas análises das silagens e análise estatística dos dados. Ao Prof. Liming Kung Jr. pelo incentivo e auxílio no planejamento do experimento.

Aos responsáveis por laboratórios, Dr. Luiz Humberto Gomes, Carlos César Alves e Regina Helena Gonçalves, pela boa vontade e competência na realização de análises essenciais ao desenvolvimento da pesquisa.

Aos professores, funcionários e estagiários do Departamento de Produção Animal que, de diversas formas, tornaram possível a realização satisfatória do curso e de todo o trabalho.

À bibliotecária Eliane, e demais funcionários da Biblioteca Central da ESALQ, pela revisão da tese e auxílio nas consultas.

À empresa LALLEMAND pelo fornecimento do inoculante bacteriano.

Especialmente aos meus irmãos, Cecília, Céres, Beatriz e Antônio Celso, aos primos Vidal e Glória e à Dona Maria Lúcia, pela compreensão e apoio durante todo o caminho. 


\section{SUMÁRIO}

Página

LISTA DE TABELAS.................................................................................. viii

LISTA DE FIGURAS.......................................................................... $\mathrm{x}$

RESUMO_............................................................................................ xiii

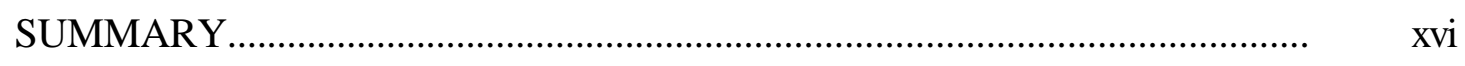

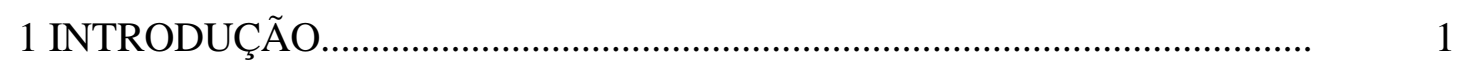

2 REVISÃO DE LITERATURA.................................................................. 3

2.1 Cana-de-açúcar fresca e ensilada na alimentação de ruminantes....................... 3

2.2 Aditivos químicos na ensilagem de cana-de-açúcar.........................................

2.3 Aditivos microbianos para silagens............................................................ 11

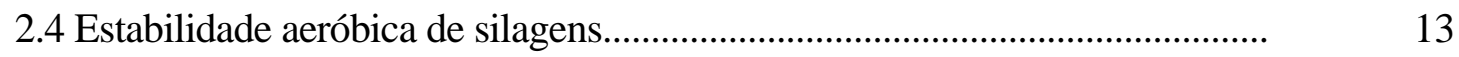

2.5 Microflora epífita e qualidade de silagens......................................................... 14

3 DINÂMICA DA FERMENTAÇÃO, DAS PERDAS DE MATÉRIA SECA E

E DESENVOLVIMENTO DA MICROFLORA EPÍFITA EM SILAGEM DE

CANA-DE-AÇÚCAR............................................................................... 17

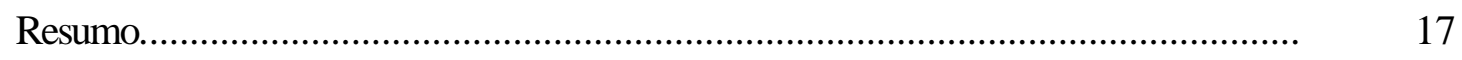

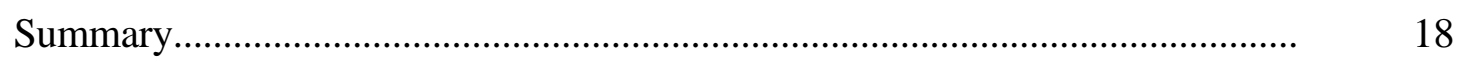

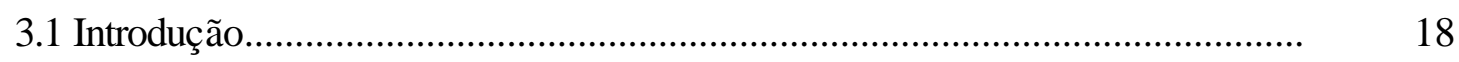

3.2 Material e Métodos.................................................................................... 20

3.2.1 Silos experimentais e produção das silagens................................................. 20

3.2.2 Avaliação das perdas e amostragem das silagens........................................... 21

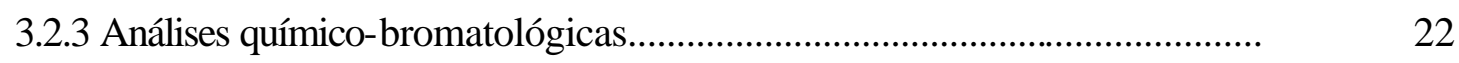


3.2.4 Caracterização da microflora epífita.............................................................. 23

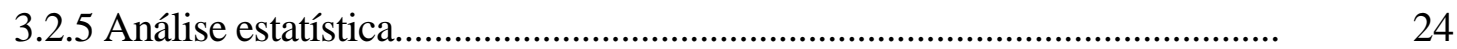

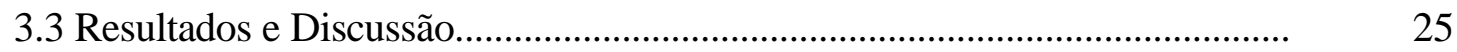

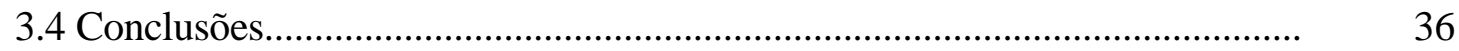

4 ADITIVOS QUÍMICOS E MICROBIANOS EM SILAGENS DE CANADE-AÇÚCAR: EFEITOS SOBRE A COMPOSIÇÃO, AS PERDAS DE MATÉRIA SECA E A ESTABILIDADE AERÓBICA.................................... 37

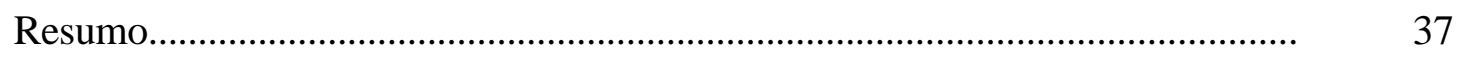

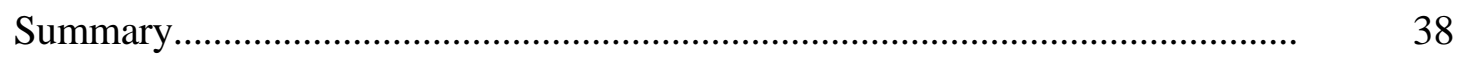

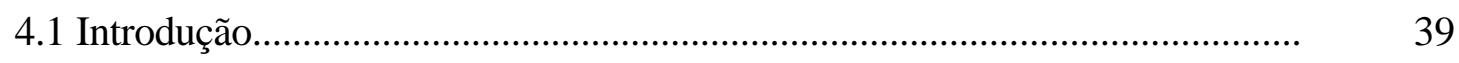

4.2 Material e Métodos.................................................................................. 41

4.2.1 Silos experimentais e produção das silagens..................................................... 41

4.2.2 Tratamentos e aplicação dos aditivos......................................................... 42

4.2.3 Avaliação das perdas e amostragem das silagens...........................................

4.2.4 Análises químico-bromatológicas................................................................. 44

4.2.5 Avaliação da estabilidade aeróbica........................................................... 45

4.2.6 Análise estatística.................................................................................... 46

4.3 Resultados e Discussão............................................................................ 46

4.3.1 Efeito dos tratamentos sobre a qualidade e as perdas de MS das silagens.... $\quad 46$

4.3.2 Efeito dos tratamentos sobre a estabilidade aeróbica das silagens.................. 58

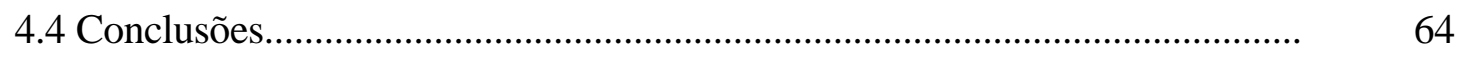

5 DINÂMICA DA FERMENTAÇÃO, DAS PERDAS DE MATÉRIA SECA E ESTABILIDADE AERÓBICA DE SILAGENS DE CANA-DE-AÇÚCAR TRATADAS COM ADITIVOS QUÍMICOS E MICROBIANOS..................... 65

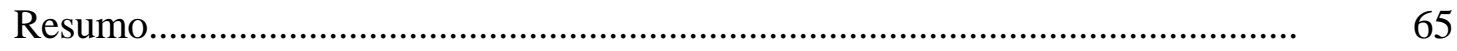

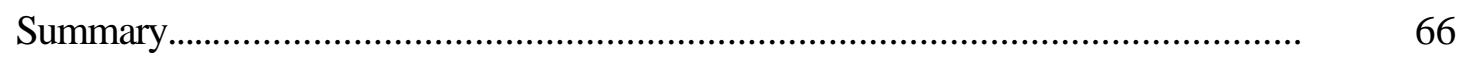

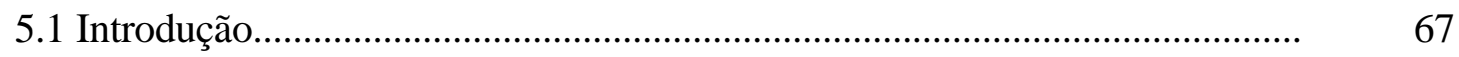

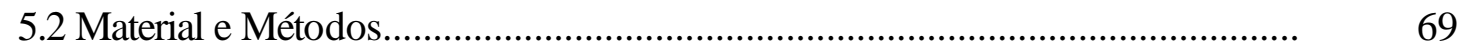

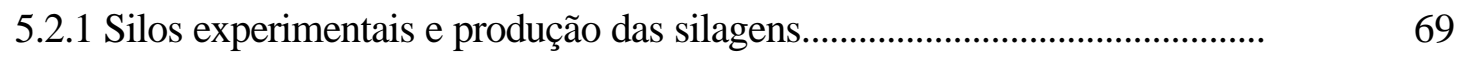

5.2.2 Tratamentos e aplicação dos aditivos......................................................... $\quad 70$ 
5.2.3 Avaliação das perdas e amostragem das silagens..........................................

5.2.4 Análises químico-bromatológicas..............................................................

5.2.5 Caracterização da microflora epífita.............................................................. 73

5.2.6 Avaliação da estabilidade aeróbica.................................................................

5.2.7 Análise estatística.......................................................................................

5.3 Resultados e Discussão..................................................................................

5.3.1 Efeito dos tratamentos, e do período de amostragem, sobre a composição e as perdas de MS das silagens................................................................... $\quad 75$

5.3.2 Efeito dos tratamentos sobre a estabilidade aeróbica das silagens................. $\quad 90$

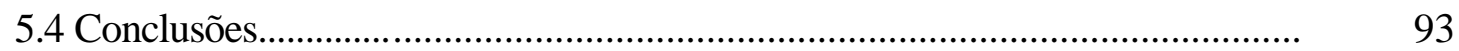

6 DESEMPENHO DE NOVILHAS DA RAÇA HOLANDESA ALIMENTADAS COM RAÇÕES A BASE DE SILAGENS DE CANADE-ÇÚCAR ADITIVADAS.................................................................... 94

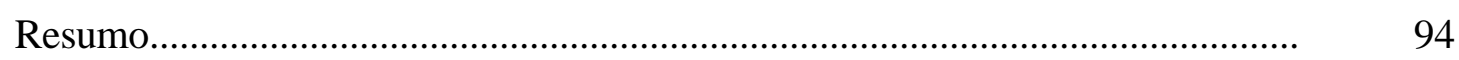

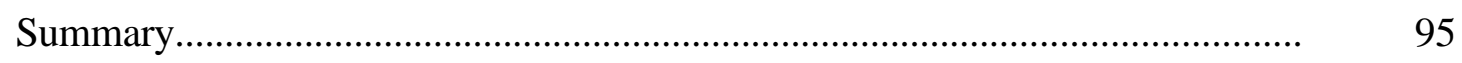

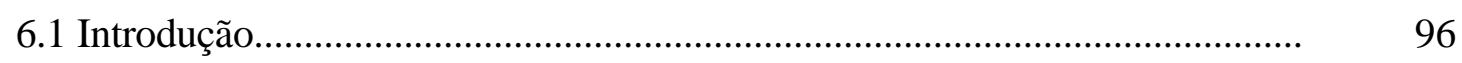

6.2 Material e Métodos..................................................................................... 97

6.2.1 Produção e tratamento das silagens............................................................... 97

6.2.2 Animais e instalações experimentais........................................................... 98

6.2.3 Tratamentos e manejo da alimentação.......................................................... 98

6.2.4 Período experimental, avaliação do consumo e pesagens dos animais.......... $\quad 100$

6.2.5 Análises químico-bromatológicas............................................................... 100

6.2.6 Análise estatística.................................................................................... 102

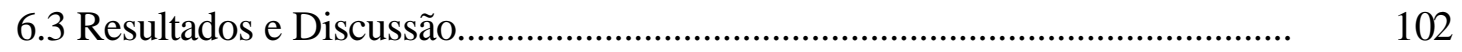

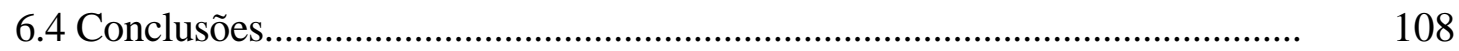

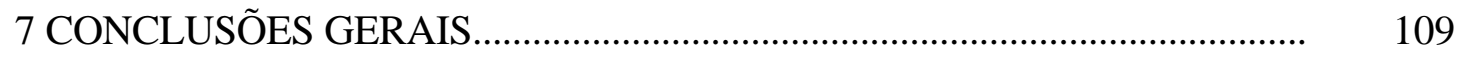

REFERÊNCIAS BILBLIOGRÁFICAS........................................................... 110 


\section{LISTA DE TABELAS}

Página

1 Composição bromatológica e perdas de MS da silagem de cana-de-açúcar, nos diversos períodos após a ensilagem.

2 Coeficientes de correlação (r) entre as variáveis qualitativas e os parâmetros referentes às perdas em silagens de cana -de-açúcar.

3 Composição bromatológica da cana-de-açúcar picada utilizada nos tratamento, antes da ensilagem.

4 Parâmetros de fermentação, de digestibilidade e de avaliação das perdas durante a ensilagem da cana-de-açúcar, sob o efeito de inoculantes microbianos e aditivos químicos

5 Parâmetros químicos das silagens de cana-de-açúcar, sob o efeito de inoculantes microbianos e aditivos químicos

6 Efeito do período de conservação sobre os valores médios dos parâmetros de fermentação, de valor nutritivo e de perdas de MS, em silagens de canade-açúcar tratadas com aditivos químicos, inoculantes microbianos e combinações entre eles

7 Composição da cana-de-açúcar fresca, pura e após a adição dos aditivos..... 
8 Composição bromatológica, perdas e população de leveduras em silagens de cana-de-açúcar, sob o efeito de aditivos químicos e microbianos, aos 94 dias após a ensilagem.

9 Composição bromatológica das silagens de cana-de-açúcar, sob o efeito de aditivos químicos e microbianos, aos 94 dias após a ensilagem.

10 Participação de ingredientes nas rações experimentais em função do tipo de silagem de cana-de-açúcar utilizada..

11 Composição bromatológica da cana-de-açúcar queimada e picada, antes da ensilagem, e das silagens experimentais.

12 Desempenho de novilhas da raça holandesa alimentadas com rações contendo silagens de cana-de-açúcar aditivadas.

13 Desempenho observado e estimado, com base nos valores reais dos pesos médios dos animais e de composição química das silagens, de novilhas holandesas em crescimento. 


\section{LISTA DE FIGURAS}

Página

1 Evolução temporal da concentração de etanol e de carboidratos solúveis em água (CHOs) na silagem de cana-de-açúcar.

2 Evolução temporal da perda de gases, da perda total de MS e da produção de efluentes da silagem de cana-de-açúcar

3 Evolução temporal da população de leveduras (expressa como logaritmo do número de unidades formadoras de colônia por grama de massa verde - log ufc/g de MV) e do teor de etanol da silagem de cana-deaçúcar.

4 Evolução temporal da população de bactérias homolácticas (expressa como logaritmo do número de unidades formadoras de colônia por grama de massa verde - log ufc/g MV), e do $\mathrm{pH}$ da silagem de cana-deaçúcar.

5 Estabilidade aeróbica e ADITE-5 em silagens de cana-de-açúcar sob o efeito da inoculação com L. plantarum (Lact), L. buchneri (Buch) e das combinações de L. plantarum com uréia (Lact/Ur 0,5 e Lact/Ur 1,0)........

6 Estabilidade aeróbica e ADITE-5 de silagens de cana-de-açúcar sob o efeito dos tratamentos com uréia e $\mathrm{NaOH}$, em diversas concentrações...... 
7 Estabilidade aeróbica e ADITE-5 de silagens de cana-de-açúcar sob o efeito dos tratamentos com propionato de cálcio (Prop), benzoato de sódio (Benz) e sorbato de potássio (Sorb), em diversas concentrações......

8 Evolução temporal do $\mathrm{pH}$ das silagens de cana-de-açúcar tratada com uréia e L. buchneri.

9 Evolução temporal do $\mathrm{pH}$ das silagens de cana-de-açúcar tratadas com benzoato de sódio, sorbato de potássio e L. plantarum.

10 Tendência temporal da concentração de etanol em silagens de cana-deaçúcar tratadas com uréia, benzoato de sódio, sorbato de potássio e inoculantes microbianos contendo L. plantarum e L. buchneri

11 Tendência temporal da perda de gases (\% da MS) de silagens de canade-açúcar tratadas com aditivos químicos (uréia, benzoato de sódio, sorbato de potássio) e inoculantes microbianos (L. plantarum, $L$. buchneri)

12 Tendência temporal da concentração de carboidratos solúveis (CHOs) de silagens de cana-de-açúcar tratadas com aditivos químicos (uréia, benzoato de sódio, sorbato de potássio) e inoculantes microbianos ( $L$. plantarum, L. buchneri).

13 Tendência temporal da perda total de matéria seca (\% da MS) de silagens de cana-de-açúcar tratadas com aditivos químicos (uréia, benzoato de sódio, sorbato de potássio) e inoculantes microbianos ( $L$. plantarum, L. buchneri). 
14 Tendência temporal da produção de efluentes $(\mathrm{kg} / \mathrm{t} \mathrm{MV})$ de silagens de cana-de-açúcar tratadas com aditivos químicos (uréia, benzoato de sódio, sorbato de potássio) e inoculantes microbianos (L. plantarum, $L$. buchneri)......

15 Tendência temporal da digestibilidade verdadeira "in vitro" da MS (DVIVMS) (\% da MS) de silagens de cana-de-açúcar tratadas com aditivos químicos (uréia, benzoato de sódio, sorbato de potássio) e inoculantes microbianos (L. plantarum, L. buchneri).

16 Estabilidade aeróbica, ADITE-5 e ADITE-10 das silagens de cana-deaçúcar tratadas com Uréia, benzoato de sódio, sorbato de potássio e inoculantes contendo L. plantarum (BAL) e L. buchneri (Buch)................ 


\title{
ADITIVOS QUÍMICOS E MICROBIANOS NO CONTROLE DE PERDAS E NA QUALIDADE DE SILAGEM DE CANA-DE-AÇÚCAR (Saccharum officinarum L.)
}

\author{
Autor: ANDRÉ DE FARIA PEDROSO \\ Orientador: Prof. Dr. LUIZ GUSTAVO NUSSIO
}

\section{RESUMO}

Este projeto de pesquisa teve como objetivo principal avaliar aditivos químicos e microbianos no controle da produção de etanol durante a ensilagem da cana-de-açúcar, com vistas à redução das perdas de matéria seca (MS) e de valor nutritivo que ocorrem durante o processo. Para tanto foram realizados três experimentos utilizando silos laboratoriais e um experimento de desempenho com bovinos em crescimento. As avaliações em laboratório foram realizadas com cana-de-açúcar colhida com aproximadamente 12 meses de crescimento e ensilada em baldes de plástico de 20 litros, adaptados com válvulas para eliminação de gases e substrato para colheita de efluentes: Experimento I: Procurou-se caracterizar a dinâmica da fermentação, das perdas de MS e de valor nutritivo e o desenvolvimento da microflora epífita na silagem. Amostragens após $1 / 2,1,2,3,7,15,45,90,120$ e 180 dias de fermentação indicaram que: a população de leveduras cresceu até o segundo dia (5,1 log ufc/g massa verde - MV); o teor de etanol atingiu nível máximo (6,4\% da MS) aos 15 dias após a ensilagem, quando observou-se desaparecimento de 68\% dos carboidratos solúveis (CHOs); aos 45 dias de ensilagem atingiu-se a maior perda total de MS (29\%), sendo esta composta por $16 \%$ de perdas gasosas; houve pequena produção de efluentes (20 kg/t MV); o pH da silagem 
apresentou queda constante atingindo 3,47 aos 180 dias; a expressiva produção de etanol, caracterizada por perda elevada de CHOs e aumento no teor de fibra causou redução da DVIVMS da forragem ensilada, de 63 para 47\%. Experimento II: O objetivo foi avaliar o efeito de uréia $(0,5 ; 1,0 ; 1,5 \%$ da MV), $\mathrm{NaOH}(1 ; 2 ; 3 \%$ da MV), propionato de cálcio-PROP $(0,05 ; 0,1 ; 0,2 \%$ da MV), benzoato de sódio-BENZ $(0,05$; 0,$1 ; 0,2 \%$ da MV), sorbato de potássio-SORB $(0,015 ; 0,03 ; 0,045 \%$ da MV), $L$. plantarum-BAL (1 x $10^{6} \mathrm{ufc} / \mathrm{g}$ de MV), L. buchneri-BUCH $\left(3,64 \times 10^{5} \mathrm{ufc} / \mathrm{g}\right.$ de MV), uréia (0,5 e 1,0\% da MV) combinada com L. plantarum-Lact/Ur 0,5\% e Lact/Ur 1,0\%, sobre o valor nutritivo, as perdas de MS e a estabilidade aeróbica das silagens. A comparação das silagens aditivadas com a silagem controle, aos 90 e 180 dias de fermentação, indicou que: os aditivos foram pouco eficientes em reduzir a concentração de etanol $(\mathrm{P}>0,05)$ e que, inclusive, os tratamentos PROP-0,1\% e BAL causaram aumento $(\mathrm{P}<0,05)$ no teor do álcool $(4,8$ e $12,5 \%$ vs 3,8\% da MS); uréia, $\mathrm{NaOH}$, SORB0,03\%, BUCH, Lact/Ur 0,5\% e Lact/Ur 1,0\% causaram diminuição da perda total de MS $(\mathrm{P}<0,05)$; as silagens tratadas com uréia, $\mathrm{NaOH}, \mathrm{BENZ}$, e SORB-0,045\% apresentaram maior DVIVMS e os tratamentos com BUCH, Lact/Ur 1,0\%, uréia-1,5\%, $\mathrm{NaOH}(1 \mathrm{e}$ $2 \%)$ e BENZ-0,2\% resultaram em silagens com maior estabilidade aeróbica $(\mathrm{P}<0,05)$. Experimento III: O objetivo foi comparar o efeito de aditivos, selecionados na fase II, sobre a dinâmica da fermentação e das perdas de MS, avaliando também a estabilidade aeróbica das silagens. Os aditivos avaliados foram: uréia ( $0,5 \%$ da MV), benzoato de sódio-BENZ (0,1\% da MV), sorbato de potássio-SORB (0,03\% da MV), L. plantarumBAL (1 x $10^{6} \mathrm{ufc} / \mathrm{g}$ de MV) e L. buchneri-BUCH $\left(3,64 \times 10^{5} \mathrm{ufc} / \mathrm{g}\right.$ de MV). Comparando-se as silagens aditivadas com a silagem controle, aos 94 dias de fermentação, concluiu-se que: a adição de uréia, BENZ, SORB e BUCH resultou em silagens com menor teor de etanol e o tratamento BAL causou aumento na concentração do álcool $(\mathrm{P}<0,05)$; uréia e SORB causaram aumentos $(\mathrm{P}<0,05)$ na perda total de MS; a aplicação de uréia resultou em aumento e a inoculação com BAL em redução na DVIVMS $(\mathrm{P}<0,05)$; o tratamento com BENZ resultou na silagem com maior $(\mathrm{P}<0,05)$ concentração de carboidratos solúveis. As curvas da tendência temporal (amostragem aos 2, 10, 31, 62, 94 e 144 dias após ensilagem) indicaram que: a concentração de etanol 
atingiu seu pico entre 60 e 90 dias de ensilagem; a perda de gases se prolongou além dos 90 dias e foi menor para o tratamento com uréia; o tratamento com BUCH resultou em tendência de maior consumo de açúcares ao longo do tempo; os tratamentos com uréia e SORB apresentaram as maiores perdas totais de MS e estimularam a produção de efluentes; a DVIVMS das silagens nos tratamentos com uréia, BENZ e SORB apresentou tendência de decréscimo linear, provavelmente como efeito da tendência de produção crescente de efluentes. Os aditivos BUCH e BENZ melhoraram a estabilidade aeróbica das silagens, em relação ao controle (78 e 72 h vs 48 h). Experimento IV: Trinta e duas novilhas holandesas $(388 \mathrm{~kg}$ ) foram alocadas a 4 tratamentos, com 4 repetições, em um delineamento em blocos. Os tratamentos consistiram em 4 tipos de rações completas contendo aproximadamente $46 \%$ da MS na forma de silagem de cana-deaçúcar, submetidas aos seguintes tratamentos: controle (sem aditivos); uréia (0,5\% da MV); benzoato de sódio-BENZ (0,1\% da MV) e Lactobacillus buchneri (BUCH, 3,64 x $10^{5}$ ufc/g de MV). O ganho de peso médio diário (GPD) mostrou aumento de $32 \%$ para BUCH e de $21 \%$ para BENZ $(\mathrm{P}<0,05)$, em comparação ao controle $(0,94 \mathrm{~kg} / \mathrm{dia})$; os tratamentos com BENZ e BUCH resultaram em melhor conversão alimentar (GPD/kg MS) em relação ao controle (7,6 e 7,7 vs 9,4); a ingestão de MS (2,2\% PV) não diferiu entre os tratamentos $(\mathrm{P}>0,10)$; o tratamento contendo silagem de cana-de-açúcar aditivada com uréia não diferiu $(\mathrm{P}>0,05)$ do controle, em nenhum dos parâmetros avaliados. A ensilagem da cana-de-açúcar, sem aditivos, tem resultado em perdas excessivas e reduzido valor nutritivo da forragem. $\mathrm{O}$ presente trabalho identificou alguns aditivos capazes de reduzir a produção de etanol, diminuindo as perdas de matéria seca nas silagens, promovendo melhor desempenho de animais com elas alimentados. 


\title{
CHEMICAL ADDITIVES AND BACTERIAL INOCULANTS ON CONTROL OF LOSSES AND QUALITY OF SUGAR CANE (Saccharum officinarum L.) SILAGE
}

\author{
Author: ANDRÉ DE FARIA PEDROSO \\ Adviser: Prof. Dr. LUIZ GUSTAVO NUSSIO
}

\section{SUMMARY}

The objective of this project was to evaluate chemical and microbial additives on ethanol control in sugar cane silages, aiming to decrease dry matter (DM) and nutritional losses during storage. Three laboratory silos trials were conducted to study fermentation process and associated losses, and one additional experiment was carried out to evaluate animal performance. For the laboratory trials sugar cane (12 months vegetative growth) was ensiled in $20 \mathrm{~L}$ plastic buckets provided with valves for gas release and a device for effluent collection: Experiment I: Aimed to characterize fermentation, DM losses and epiphytic microflora dynamics during ensilage. Silage sampling at $1 / 21,2,3,7,15,45$, 90, 120 and 180 days after sealing indicated: intensive growth of yeast population until day two of fermentation (5.1 $\log \mathrm{cfu} \mathrm{g}^{-1}$ ); ethanol reached its highest content after 15 days from sealing $(6.4 \%$ in $\mathrm{DM})$ when $68 \%$ of the water soluble carbohydrates (CHOs) disappeared; total DM (29\%) and gases (16\% of the DM) losses reached a plateau after 45 days of ensilage; effluent yield was negligible $\left(20 \mathrm{~kg} \mathrm{t}^{1}\right)$; silage $\mathrm{pH}$ was lowest after 180 days of storage (3.47); ethanol production led to increased CHOs loss and higher fiber content in the silage, which in turn were associated with reduction in silage's IVDDM (63 to 47\%). Experiment II: The main objective was to evaluate the addition of 
wet basis): urea $(0.5,1.0,1.5 \%), \mathrm{NaOH}(1,2,3 \%)$, calcium propionate-PROP $(0.05,0.1$, $0.2 \%)$, sodium benzoate-BENZ $(0.05,0.1,0.2 \%)$, potassium sorbate-SORB $(0.015,0.03$, $0.045 \%)$, L. plantarum-LAB (1 x $\left.10^{6} \mathrm{cfu} \mathrm{g}^{-1}\right)$, L. buchneri-BUCH $\left(3.64 \times 10^{5} \mathrm{cfu} \mathrm{g}^{-1}\right)$, urea $(0.5$ e $1.0 \%$ fresh basis) plus L. plantarum-Lact/Ur $0.5 \%$ and Lact/Ur $1.0 \%$ on silage quality, DM losses and aerobic stability. Comparison of treated silages with control after 90 and 180 days from sealing indicated: none of the additives were effective to decrease ethanol concentration in silages and PROP-0.1\% and LAB even increased $(\mathrm{P}<0.05)$ alcohol levels $(4.8$ and $12.5 \%$ vs $3.8 \%$ in control $\mathrm{DM})$; urea, $\mathrm{NaOH}$, SORB- $0.03 \%$, BUCH, Lact/Ur $0.5 \%$ and Lact/Ur $1.0 \%$ treated silages showed lower total DM losses $(\mathrm{P}<0.05)$; higher IVDDM was achieved by adding urea, $\mathrm{NaOH}, \mathrm{BENZ}$ and SORB-0.045\% ( $\mathrm{P}<0.05)$; aerobic stability was improved with BUCH, Lact/Ur 1.0\%, urea-1.5\%, $\mathrm{NaOH}(1$ and $2 \%)$ and BENZ-0.2\% treatments $(\mathrm{P}<0.05)$. Experiment III: The objective was to compare the effects of additives screened in experiment II based on silage fermentation traits, DM losses and aerobic stability. Treatments were (wet basis): urea $(0.5 \%)$, sodium benzoate-BENZ $(0.1 \%)$, potassium sorbate-SORB $(0.03 \%), L$. plantarum-LAB $\left(1 \times 10^{6} \mathrm{cfu}^{-1}\right)$ e L. buchneri-BUCH $\left(3.64 \times 10^{5} \mathrm{cfu} \mathrm{g}^{-1}\right)$. Comparing treated silages with control after 94 days from sealing indicated: urea, BENZ, SORB and BUCH resulted in silages with less etanol, however LAB resulted in higher ethanol concentration $(\mathrm{P}<0.05)$; urea and SORB treatments decreased total DM losses $(\mathrm{P}<0.05)$; IVDDM was higher for urea and lower for LAB treated silages $(\mathrm{P}<0.05)$; CHOs content was higher in $\mathrm{BENZ}$ treated silage $(\mathrm{P}<0.05)$. Regression slopes performed through 144 days after sealing indicated: ethanol yield was maximum between 60 and 90 days; gases losses were extended up to 90 days and was lower in urea treated silages; BUCH inoculated silages showed a trend to loose more CHOs; treatment with urea and SORB resulted in silages with increased total DM and effluent losses; IVDDM reduced linearly with time in chemically treated silages, probably due to the increased effluent yield. BUCH and BENZ improved silages aerobic stability over control (78 and $72 \mathrm{~h}$ vs $48 \mathrm{~h}$ ). Experiment IV: Thirty two Holstein heifers $(388 \mathrm{~kg})$ were allocated to 4 treatments, 4 replications each, in a block design. The animals were fed total mixed rations containing $46 \%$ sugar cane silage, within the following treatments (wet basis): control (without 
additive), urea (0.5\%), sodium benzoate-BENZ (0.1\%) e Lactobacillus buchneri-BUCH $\left(3.64 \times 10^{5} \mathrm{cfu} \mathrm{g}^{-1}\right)$. Average daily gain $(\mathrm{ADG})$ showed $21 \%$ increase $(\mathrm{P}<0.05)$ for BENZ and $32 \%$ for BUCH over control $\left(0.9 \mathrm{~kg} \mathrm{~d}^{-1}\right)$; better feed conversions (DMI/ADG) were observed for BENZ and BUCH (7.6 and 7.7 vs 9.4); DM intake (2.2\% $\mathrm{BW})$ did not differ $(\mathrm{P}>0.10)$ across treatments. Urea treated silage was similar to control in all traits $(\mathrm{P}>0.05)$. 


\section{INTRODUÇÃO}

A cultura da cana-de-açúcar no Brasil recebeu grande incentivo através do programa Proálcool, o que resultou em avanço nas técnicas de cultivo e no lançamento de variedades com maior potencial de produção de biomassa e açúcar. Consequentemente, houve também a expansão da cultura para regiões tradicionais de pecuária e de produção de grãos, criando a oportunidade do seu uso em confinamentos de bovinos de corte.

A alimentação de bovinos apresenta-se também como destino alternativo para a cana-de-açúcar quando ocorrem reduções nos preços do açúcar e do álcool, exigindo que os produtores diminuam a oferta de cana para as usinas e que glebas sejam liberadas para o estabelecimento de outro tipo de cultura, evitando-se assim que sobras permaneçam no campo, tornando-se canas "bisadas", de baixa qualidade e sujeitas ao "acamamento", o que dificulta a colheita.

A utilização da cana-de-açúcar, colhida diariamente e fornecida fresca aos animais, é tradicional e de amplo conhecimento dos pecuaristas, porém, o manejo industrial de canaviais exige que o corte dos talhões seja realizado de forma concentrada, para aumentar a eficiência dos tratos culturais. Além disso, o corte diário torna-se problemático em situações onde se deseja utilizar a cana como forragem durante o ano todo, devido à dificuldade de colheita em dias de chuva e à perda no seu valor nutritivo durante o verão. Canaviais que tenham sido submetidos à queima, ou que tenham sofrido fortes geadas, também precisam ser utilizados rapidamente para não serem perdidos.

A ensilagem da cana-de-açúcar apresenta-se como solução para tais problemas, permitindo a colheita de grandes áreas num curto espaço de tempo, na época em que a 
forrageira apresenta seu melhor valor nutritivo, o que coincide com o período mais propício aos trabalhos no campo, ou seja, durante a seca. Porém, o alto teor de carboidratos solúveis e a grande população de leveduras epífitas levam à fermentação alcoólica quando a cana-de-açúcar é ensilada, causando perdas excessivas de matéria seca e de valor nutritivo da forragem.

Aditivos químicos e inoculantes microbianos têm sido utilizados com o intuito de melhorar o padrão de fermentação e conservação das silagens, promovendo o desenvolvimento dos microrganismos benéficos, como as bactérias produtoras de ácido lático, e a inibição dos indesejáveis, como as leveduras e clostridia.

Apesar da crescente demanda de informações sobre a ensilagem da cana-deaçúcar, observa-se reduzido desenvolvimento científico em relação ao uso de aditivos para o controle da produção de etanol e aumento da estabilidade aeróbica destas silagens, que são aspectos fundamentais nesta forma de preservação da forragem.

Com base na hipótese de que, o uso estratégico de aditivos pode inibir o desenvolvimento de leveduras, reduzindo consequentemente a produção de etanol, as perdas de matéria seca e de valor nutritivo durante a ensilagem da cana-de-açúcar, desenvolveu-se o presente estudo, que teve os seguintes objetivos: estudar a dinâmica da fermentação, das perdas de matéria seca e das alterações no valor nutritivo da canade-açúcar ensilada sem aditivos, estabelecendo ainda o padrão de crescimento da microflora epífita (capítulo 3); determinar o efeito de inoculantes microbianos e aditivos químicos, em diversas doses, sobre a fermentação, as perdas de matéria seca, a qualidade e a estabilidade aeróbica de silagens de cana-de-açúcar (capítulo 4); caracterizar o efeito de aditivos químicos e microbianos sobre a dinâmica da fermentação, das perdas de MS e das mudanças no valor nutritivo em silagens de cana-de-açúcar (capítulo 5); avaliar o desempenho de bovinos em crescimento alimentados com rações contendo silagens de cana-de-açúcar aditivadas (capítulo 6). 


\section{REVISÃO DE LITERATURA}

\subsection{Cana-de-açúcar fresca e ensilada na alimentação de ruminantes}

A cana-de-açúcar (Saccharum officinarum L) é utilizada há muito tempo como cultura forrageira pelos pecuaristas no Brasil. Levantamentos realizados na década de 50 relataram que $75 \%$ dos estabelecimentos produtores de leite utilizavam esta forragem na alimentação dos rebanhos. Recentemente, a cana-de-açúcar vem assumindo papel fundamental nos confinamentos para terminação de bovinos de corte, pois apresenta uma série de características desejáveis, como: grande produção de forragem por unidade de área (80 a 150 t/ha); baixo custo de produção por tonelada de matéria seca (MS); manutenção do valor nutritivo por até 6 meses após a maturação; época de colheita coincidente com o período de escassez de forragem nas pastagens (Silva, 1993).

Entre as diversas vantagens da utilização da cana-de-açúcar na alimentação animal, ressalta-se o fato de ser esta espécie forrageira a de maior potencial de produção de MS e energia, por unidade de área, em um único corte, atingindo produções entre 15 a $20 \mathrm{t}$ de nutrientes digestíveis totais (NDT) por hectare, em comparação com o milho, o sorgo e a mandioca que produzem cerca de $8 \mathrm{t}$ de NDT/ha (Lima e Mattos, 1993).

Quando utilizada como alimento exclusivo para ruminantes, a cana-de-açúcar possui limitações importantes do ponto de vista nutricional, devido ao desequilíbrio de nutrientes, apresentando teores muito baixos de proteína bruta e da maioria dos minerais, principalmente de fósforo. A ingestão voluntária de MS e a utilização da energia digerida da cana-de-açúcar são baixas, apesar da digestibilidade ser considerada como de valor intermediário (54 a 65\% da MS) (Boin e Tedeschi, 1993). 
É de conhecimento geral que o desempenho dos animais pode ser satisfatório quando a cana-de-açúcar é corrigida, quanto aos teores de proteína e minerais. A adição de 0,5 a 1,0\% da mistura uréia/sulfato de amônio (9:1) à forragem, juntamente com o fornecimento suplementar de farelos, como fonte de proteína e carboidratos de menor solubilidade, tornou-se uma técnica bastante difundida e permite a obtenção de resultados satisfatórios de consumo e ganho de peso. Hernandez (1998) obteve taxas de ganho de peso variando entre 1,53 e 1,81 kg por dia, para bovinos de corte alimentados com rações contendo cana-de-açúcar como volumoso único (48\% da MS), suplementados com misturas concentradas compostas por milho, farelo de soja, uréia e minerais, sendo que as rações apresentaram digestibilidade da matéria orgânica entre 67,3 e $72,2 \%$. Em recente teste de variedades de cana-de-açúcar, Rodrigues et al. (2002) obtiveram taxas de ganho de peso entre 0,89 e 0,65 kg/dia, para novilhas da raça Canchim alimentadas com cana-de-açúcar suplementada com $1,3 \mathrm{~kg} /$ cabeça/dia de concentrado.

A capacidade da cana-de-açúcar em manter seu valor nutritivo durante um longo período de tempo, sendo este período coincidente com a época de baixa disponibilidade de forragem nos pastos, ou período da seca, permite que em pequenas propriedades, a cana seja colhida diariamente e fornecida fresca aos animais, em um sistema que, apesar de exigir disciplina diária, garante a utilização de forragem de qualidade adequada aos animais. No entanto, nos confinamentos industriais de gado de corte e nas grandes fazendas produtoras de leite, a colheita diária da cana dificulta os tratos culturais nas áreas de cultivo e a reforma dos canaviais, que terão sempre plantas em diversos estágios de desenvolvimento.

A utilização da cana-de-açúcar na alimentação animal, fora do período da safra, também sofre restrições, porque a forragem apresenta menor valor nutritivo, devido ao baixo teor de sacarose (Matsuoca e Hoffmann, 1993), e durante a época das chuvas a movimentação de máquinas no campo é difícil, causando a morte de plantas e prejudicando a manutenção do "stand" nos talhões..

Por estes motivos, tem sido grande a demanda por informações sobre a ensilagem da cana-de-açúcar, técnica que permite que grandes áreas sejam cortadas em um curto 
espaço de tempo, na época em que a cana apresenta seu melhor valor nutritivo e que é a estação do ano mais propícia à movimentação de máquinas no campo. Nos casos de incêndio acidental dos canaviais, e na ocorrência de geadas, a ensilagem da cana pode ser ainda a única forma de evitar a perda total da forragem.

Apesar da escassez de pesquisa nacional nesta área, alguns trabalhos demonstraram que silagens produzidas exclusivamente com cana-de-açúcar são de baixa qualidade, levando à redução no consumo voluntário, na taxa de ganho de peso e na conversão alimentar dos animais com elas alimentados, em comparação aos mesmos índices de animais alimentados com cana fresca. Mesmo assim, a ensilagem desta forragem tem sido realizada em nosso país, sem a devida preocupação com os problemas que apresenta.

A cana-de-açúcar, quando ensilada sem aditivos, apresenta fermentação alcoólica e perda no valor nutritivo, como foi constatado por Preston et al. (1976) que verificaram redução de aproximadamente $30 \%$ no conteúdo total dos açúcares para a cana ensilada em relação à cana fresca, e teor alcoólico de 5,5\% da MS da silagem. Na República Dominicana, González \& MacLeod (1976) observaram que a cana ensilada sem aditivos apresentou redução acentuada no $\mathrm{pH}$ (de 4,2 para 2,9), redução no valor de graus brix (de 13,8 para 9,0) e produção significativa de ácido acético (0,96\% da MS), ressaltando que houve o desenvolvimento de leveduras e conseqüente produção de álcool (1,4\% da MS).

Estudando a fermentação de cana-de-açúcar em silos laboratoriais, Alli et al. (1982) observaram teor de etanol de 8,86\% na MS da silagem, com redução de $90 \%$ no teor de carboidratos solúveis em água, aumento no teor de FDA (de 29,9 para 43,1\% da MS) e 5,2\% de perdas gasosas, no período de apenas dez dias após a ensilagem. Os autores salientaram que a produção de álcool deve ter correspondido ao consumo de aproximadamente $50 \%$ da sacarose presente na cana fresca, sendo as leveduras as responsáveis por este tipo de fermentação, e que o restante das perdas seria devido principalmente ao consumo de açúcares durante a fase aeróbica, pela respiração da planta, e em menor quantidade pela produção de ácidos pelas bactérias anaeróbicas. 
Kung Jr. \& Stanley (1982) constataram produção crescente de álcool em silagens de cana-de-açúcar ensiladas com seis, nove e 12 meses de crescimento (7,5 9,5 e 15,5\% da MS, respectivamente), com conseqüente diminuição no valor energético da forragem, evidenciando que, o processo de ensilagem pode neutralizar o efeito benéfico do amadurecimento sobre o valor nutritivo desta espécie forrageira (Boin \& Tedeschi, 1993).

A diminuição do valor nutritivo da cana-de-açúcar com a ensilagem, foi relatada por Alcântara et al. (1989) que observaram redução na digestibilidade "in vivo" da MS (66,4 vs 55,3\%) e menor consumo voluntário (7,1 vs 5,7\% PV $\left.{ }^{0,75}\right)$ em carneiros machos alimentados com silagem, em relação aos que receberam a forragem fresca, tendo sido as dietas suplementadas com uréia e minerais.

Alguns trabalhos de pesquisa têm sido realizados no Brasil, no campo da ensilagem da cana-de-açúcar, que demonstram a produção excessiva de etanol e a perda de valor nutritivo das silagens. Bernardes et al. (2002), constataram teor de 6,87\% de etanol na MS da silagem, para cana-de-açúcar ensilada aos 12 meses de crescimento. Coan et al. (2002) avaliando a composição química da cana-de-açúcar madura (12 meses de rebrota) ensilada em microsilos de PVC, durante 55 dias, relataram diminuição no teor de MS (27,3 is 20,9\%), aumento nos constituintes da parede celular, com maiores concentrações de FDN (42,1 vs 54,95\%), de FDA (34,9 vs 43,8\%,) e de lignina (6,8 vs 7,2\%), para a silagem em relação à cana fresca.

O padrão de fermentação de silagens de cana-de-açúcar, ensilada após 12 meses de crescimento (primeiro corte) em microsilos de PVC, foi estudado por Molina et al. (2002), através da amostragem de silagens com 1, 3, 5, 7, 14, 28 e 56 dias de conservação. Detectou-se redução no teor de MS da silagem, entre o primeiro e o último dia considerados, de 27,94 para 21,58\%, porém não houve diferença para os valores de $\mathrm{pH}(3,43$ vs 3,43$)$ e PB (2,30 vs $2,70 \%$ da MS). 


\subsection{Aditivos químicos na ensilagem de cana-de-açúcar}

Os primeiros testes com aditivos para controle do desenvolvimento de leveduras em silagens de cana, foram baseados nos resultados promissores de experimentos pioneiros que avaliaram o uso de aditivos $\left(\mathrm{NH}_{3}\right.$-solução) para o controle de leveduras e mofos em silagens de milho (Britt et al., 1975). Desde então, diversos aditivos têm sido avaliados visando melhorar o padrão de fermentação, o controle do desenvolvimento de leveduras e a conservação da cana-de-açúcar na forma de silagem.

Preston et al. (1976) avaliando o uso de amônia aquosa e amônia com melaço, como forma de favorecer a multiplicação das leveduras em detrimento da produção de álcool, relataram redução na perda de açúcares solúveis e eliminação total da produção de etanol nas silagens. Alvarez \& Preston (1976) testaram soluções contendo amônia aquosa e melaço, em comparação com outra contendo uréia e melaço, tendo detectado que ambas soluções apresentaram efeito positivo sobre a preservação das silagens, porém com efeito superior da amônia, que resultou em menor perda de açúcares solúveis.

O desempenho de bovinos alimentados com dietas contendo silagens de cana-deaçúcar tratada com soluções contendo uréia e/ou amônia, foi avaliado por Silvestre et al. (1976) e Alvarez et al. (1977). Nesses trabalhos constatourse que, o consumo de silagem tratada com $1 \%$ de uréia, foi $39 \%$ superior ao da silagem sem aditivo e semelhante ao da cana fresca. Houve uma tendência da silagem de cana tratada com $2 \%$ de uma solução de melaço com amônia ser $16 \%$ superior, e a silagem de cana sem aditivos $17 \%$ inferior, em relação àcana fresca, para ganho de peso e conversão alimentar.

Alli et al. (1983) avaliaram o padrão de fermentação de silagem de cana-deaçúcar aditivada $(16,9 \mathrm{~kg} \mathrm{NH} / \mathrm{t}$ de $\mathrm{MS})$, constatando redução na população inicial de leveduras e mofos, menor produção de etanol, redução nas perdas de MS em 67,5\% e de carboidratos solúveis em 47\%, aumento no teor de ácido lático e redução no teor de FDA. Ocorreu, no entanto, produção de ácido butírico na silagem tratada. Num segundo experimento, utilizando menor concentração do aditivo (3,42 $\mathrm{kg} \mathrm{NH} / \mathrm{t}$ de $\mathrm{MS}$ ), os mesmos pesquisadores detectaram melhor qualidade na silagem tratada, sem a produção 
de ácido butírico, no entanto esta apresentou maiores perdas de MS e de carboidratos solúveis, além da maior concentração de etanol. Estes resultados sugeriram que, a concentração de amônia que resultaria em boa preservação da silagem, sem a produção excessiva de ácido butírico, deveria situar-se entre as duas concentrações utilizadas.

Trabalhos de pesquisa publicados recentemente no Brasil, relataram que silagens de cana-de-açúcar tratadas com níveis entre 0,5 e 1,5\% de uréia, propiciaram bom padrão de fermentação e melhor composição bromatológica, como teor mais elevado de MS e teores mais baixos de FDA e FDN, em comparação à silagem de cana exclusiva (Lima et al., 2002; Molina et al., 2002).

A capacidade de substâncias alcalinizantes em modificar o processo fermentativo de silagens foi demonstrado primeiramente por Tufino et al. ${ }^{1}$, citados por Castrillón et al. (1978), que obtiveram redução na fermentação alcoólica em silagem de cana-deaçúcar com a adição de 4\% de $\mathrm{NaOH}$. Castrillón et al. (1978) estudaram o valor alimentício e o padrão de fermentação ruminal para ovinos alimentados com silagem de cana-de-açúcar tratada com 4\% de $\mathrm{NaOH}$ (\% da MS), observando melhoria na composição bromatológica, redução acentuada na produção de etanol (de aproximadamente 5,2 para $0,88 \%$ da MS), maior teor de ácido lático, aumento no consumo e no ganho de peso dos animais, em relação à silagem sem aditivo. Alcántara et al. (1989) estudando o efeito da adição de 3\% de $\mathrm{NaOH}$ (\% da MS) na ensilagem de cana-de-açúcar, observaram maior fluxo total de nitrogênio e maior eficiência na síntese de proteína microbiana no rúmen dos animais alimentados com a silagem tratada, o que possibilitou consumo voluntário e digestibilidade da MS maiores do que os obtidos com silagem de cana sem aditivo e iguais ao da cana fresca.

Alguns outros produtos químicos, apresentam potencial como aditivos na ensilagem da cana-de-açúcar, quando o objetivo é o controle do desenvolvimento das leveduras, embora não tenham sido anteriormente testados com este fim. Os ácidos graxos saturados, contendo até 12 carbonos, apresentam atividade anti-microbiana, e a

\footnotetext{
T TUFINO, S.; CALDERÓN, F.; SHIMADA, As. Efecto de la adición de hidróxido de sódio al ensilar caña de azucar em su composición. Resúmenes de la $2^{\mathrm{a}}$ Reunión Internacional de La Caña De Azucar em la Alimentación Animal, Oaxtepec, Morelos, Méx.1978.
} 
atividade aumenta com o aumento no tamanho da cadeia carbônica dos ácidos, e com a diminuição do pH, como foi relatado por Woolford (1975). Segundo esse autor, os ácidos butírico, valérico e capróico, apesar de serem eficientes na inibição do desenvolvimento de leveduras, estão associados a silagens que apresentam fermentação butírica e podem ocasionar rejeição do alimento pelos animais, por terem odor desagradável. Afirmou ainda que, os ácidos de cadeia carbônica mais longa mostraramse efetivos contra bactérias e fungos, em menores concentrações do que os de cadeia curta, mas apresentam custo elevado, e que em pH 5 e 6, os ácidos fórmico, acético e propiônico inibiram clostridia e bacilos, mais do que a outros grupos de microrganismos, entretanto em $\mathrm{pH} 4$ e 3 o efeito inibitório sobre mofos e leveduras foi aumentado. $\mathrm{O}$ efeito dos ácidos, neste caso, aumentou com o tamanho da cadeia, sendo o ácido propiônico o mais eficiente.

A ação dos ácidos graxos de cadeia curta sobre as leveduras foi demonstrada em experimentos que avaliaram a estabilidade aeróbica de silagens, já que os fungos são responsáveis por grande parte das perdas de material digerível quando as silagens são expostas ao ar. Ohyama et al. (1975), relataram que a adição de $0,5 \%$ de propionato de sódio melhorou a estabilidade aeróbica de silagens de azevém, mas que em alguns casos as silagens foram instáveis mesmo com altas concentrações do ácido. Britt et al (1975) constataram que a adição de ácido propiônico, ácido fórmico e ácido acético, puros ou conjugados, retardou o aquecimento e aumentou o tempo até o aparecimento de fungos visíveis em silagens de milho expostas ao ar, sendo que as silagens tratadas com mais de $1 \%$ de ácido propiônico (puro ou em mistura) não apresentaram aumento no número de colônias de fungos, durante todo o tempo de avaliação.

Mann \& McDonald (1976) avaliaram o efeito dos ácidos fórmico, acético e propiônico, separadamente e conjugados entre si e com formalina, sobre silagem de Lolium multiflorum, em silos laboratoriais, numa taxa de aplicação constante de 4,5 g/kg de forragem fresca. As misturas dos ácidos fórmico/acético, fórmico/propiônico, acético/propiônico e fórmico/acético/propiônico, resultaram em silagens com menor contagem de leveduras. Quanto à estabilidade aeróbica, os melhores resultados foram obtidos para os tratamentos com ácido fórmico, formalina/fórmico/acético, ácido 
acético, ácidos fórmico/acético/propiônico e ácido propiônico, nesta ordem, sendo que a combinação ácidos fórmico/acético/propiônico foi a que resultou em silagem com menor perda de carboidratos solúveis.

Moon (1983), citando Gershon \& Shanks ${ }^{2}$ afirmou que, apesar de todos os ácidos graxos inibirem o crescimento da maioria das bactérias e leveduras, sua ação depende do $\mathrm{pH}$, com maior efeito abaixo do $\mathrm{pK}_{\mathrm{a}}$ dos ácidos (4,73 p/ acetato; 4,87 p/ propionato; 3,86 $\mathrm{p} /$ lactato), e que algumas linhagens de Saccharomyces sp, Geotrichum sp, Endomycopsis sp e Hansenula sp podem utilizar acetato e lactato para seu crescimento, em condições aeróbicas, sendo no entanto inibidas por maiores concentrações destes ácidos e por baixas concentrações de propionato. No entanto, Ranjit \& Kung, Jr. (2000) não constataram efeito da aplicação de um produto comercial contendo ácido propiônico tamponado, entre outros aditivos, sobre a fermentação e estabilidade aeróbica de silagens de milho, sobre a população de leveduras e a concentração de etanol na forragem.

Segundo McDonald et al. (1991) o uso do ácido acético tem sido evitado por muitos pesquisadores porque sua presença, em altas concentrações, nas silagens tem sido associada com baixo desempenho animal, resultante de baixo consumo voluntário de matéria seca. Observaram estes autores, no entanto, que alguns estudos mostraram que o acetato induz apenas a uma redução pequena do consumo (em ovinos) e que os problemas devem advir do processo de produção do acetato na silagem, e não do efeito direto do ácido.

Alguns agentes germicidas, utilizados como conservantes na indústria alimentícia, têm sido testados como aditivos para silagem. Os ácidos sórbico e benzóico, foram avaliados em laboratório por Woolford (1975). Nesse trabalho, o ácido sórbico na forma de sorbato de potássio, mostrou poder inibidor sobre clostridia, leveduras e mofos. O ácido benzóico, na forma de benzoato de sódio foi altamente eficiente contra clostridia, porém precisou ser aplicado em altas concentrações para ser efetivo contra

\footnotetext{
2 GERSHON, H.; SHANKS, L. Antifungal activity of fatty acids and derivatives: structure activity relationships. In: Kabara, A (ed). The pharmacological effect of lipids. Champaign: The American Oil Chemists' Society, 1978. p. 51-62.
} 
leveduras (55 mM a pH 5, equivalente a 7,2 kg/t). Lättemäe \& Lingvall (1996) constataram efeito positivo sobre a conservação de silagens de capim emurchecido, com a adição de benzoato e nitrito de sódio, combinados à hexamina, que causaram redução no número de leveduras e diminuição na perda de carboidratos solúveis das silagens, quando estas foram expostas ao ar.

\subsection{Aditivos microbianos para silagens}

A elevação artificial do número inicial de bactérias produtoras de ácido lático, na forragem ensilada, pode reduzir o pH final, aumentar o conteúdo de ácido lático, diminuir a produção de efluentes e a perda de matéria seca no silo, melhorando o desempenho e a produção de leite dos animais alimentados com a silagem tratada (McDonald et al., 1991). Segundo Muck (1993), que compilou os dados de 250 experimentos realizados entre 1985 e 1992, o uso de inoculantes contendo bactérias homoláticas causou melhora significativa, na fermentação das silagens, em 75\% dos estudos com alfafa, em $77 \%$ dos estudos com gramíneas, mas em apenas $40 \%$ dos estudos com milho.

Os inoculantes comerciais contêm, normalmente, linhagens de bactérias homofermentativas produtoras de ácido lático como, Lactobacillus plantarum, Pediococcus acidilactici, Streptococus faecium, Enterococcus faecium e Lactococcus lactis. Recentemente inoculantes contendo bactérias heterofermentativas, produtoras de ácido acético e propiônico, como Lactobacillus buchneri, Pediococus cerevisiae, Propionibacterium shermani e Propionibacterium acidipropionici, têm sido avaliados buscando melhorar a estabilidade aeróbica das silagens, o que implica no controle da população de leveduras e, no caso de serem eficientes, indicaria bom potencial de uso na ensilagem da cana-de-açúcar, mas os resultados nesta área têm sido variáveis. Higginbotham et al. (1998), comparando inoculantes contendo bactérias produtoras de ácido propiônico (P. acidipropionici), bactérias homofermentativas produtoras de ácido lático (L. plantarum e P. cerevisiae) e inoculantes contendo a combinação dos dois tipos de bactérias, não detectaram efeito da inoculação sobre a composição das silagens mas 
observaram maiores perdas de matéria seca, em relação à silagem sem inoculante. A aplicação dos inoculantes contendo bactérias produtoras de ácido propiônico não afetou o número de leveduras, mofos e lactobacilos, antes ou depois da abertura dos silos e a temperatura das silagens elevou-se intensamente, quando estas foram expostas ao ar. Segundo os autores, a adição das bactérias produtoras de ácido propiônico não alterou o processo fermentativo das silagens, devido à incapacidade destas bactérias em se desenvolverem nas condições de acidez encontradas nos silos, e o aumento nas perdas de matéria seca foi devido ao teor excessivo de umidade das silagens, favorecendo a intensa fermentação das silagens inoculadas. No entanto, Driehuis \& Wikselaar (2000) relataram que, para silagens de capim azevém (L. perenne) emurchecido (48\% de MS), a aplicação de bactérias homoláticas L. plantarum e E. faecium resultou na diminuição da produção de etanol (1,3 vs 6,3\% da MS) e das perdas de MS (2,6 vs 7,4\%), embora não tenham sido identificados os microrganismos responsáveis pela fermentação alcoólica nas silagens.

Aditivos contendo bactérias heteroláticas que produzem ácido acético, além do ácido lático, têm apresentado bom potencial como forma de melhorar a estabilidade aeróbica das silagens, devido ao maior poder daquele ácido de inibir o crescimento de leveduras e mofos.

O etanol pode ser gerado durante a fermentação heterolática, dependendo do substrato utilizado e da espécie de bactéria envolvida no processo. Neste tipo de fermentação, a glicose e a frutose são degradadas pela via 6-fosfogluconato até gliceraldeído-3-fosfato e acetilfosfato. O gliceraldeído é oxidado a piruvato, que é reduzido a lactato na via homofermentativa. O acetilfosfato age como receptor de hidrogênio e é reduzido a etanol ou acetato. A proporção de etanol e acetato depende do potencial oxi-redutor do sistema, se receptores adicionais de hidrogênio, como o oxigênio e a frutose estiverem disponíveis, não há a formação de etanol, o oxigênio é reduzido a peróxido de hidrogênio e a frutose é reduzida a manitol (McDonald et al., 1991). As reações mencionadas podem ser resumidas como segue: 


$$
\begin{aligned}
& \text { Glicose }+\mathrm{ADP}+\mathrm{Pi} \rightarrow \text { Lactato }+ \text { Etanol }+\mathrm{CO}_{2}+2 \mathrm{ATP}+\mathrm{H}_{2} \mathrm{O} \\
& 3 \text { Frutose }+2 \mathrm{ADP}+2 \mathrm{Pi} \rightarrow \text { Lactato }+ \text { Acetato }+2 \mathrm{Manitol}+\mathrm{CO}_{2}+2 \mathrm{ATP}+\mathrm{H}_{2} \mathrm{O} \\
& \text { Glicose }+2 \text { Frutose }+2 \mathrm{ADP}+2 \mathrm{Pi} \rightarrow \text { Lactato }+ \text { Acetato }+2 \mathrm{Manitol}+\mathrm{CO}_{2}+2 \mathrm{ATP}+\mathrm{H}_{2} \mathrm{O}
\end{aligned}
$$

As bactérias L. buchneri, no entanto, não produzem etanol na fermentação aneróbica da glucose, porque não possuem a enzima acetaldeído desidrogenase. A glucose será fermentada a acetato se houver um receptor de hidrogênio, como a frutose, que será então reduzida a manitol (McDonald et al., 1991). Segundo Driehuis et al. (1999), as bactérias L. buchneri são capazes de metabolizar o ácido lático a ácido acético e 1,2-propanodiol, de forma que em silagens de milho inoculadas com estas bactérias ocorre o acúmulo de ácido acético às expensas do ácido lático. Confirmando estes fatos, Ranjit \& Kung, Jr. (2000), em experimento onde avaliaram inoculantes contendo estas bactérias na ensilagem do milho, observaram aumento na produção do ácido acético, que resultou em aumento significativo na estabilidade aeróbica e redução na população de leveduras das silagens tratadas. Taylor \& Kung, Jr. (2002) testando níveis de aplicação de L. buchneri em concentrações na ordem de $10^{5}$ a $10^{6}$ unidades formadoras de colônia (ufc)/g de forragem, constataram que níveis iguais ou superiores a $5 \times 10^{5} \mathrm{ufc} / \mathrm{g}$ foram eficientes no controle do desenvolvimento de leveduras e no aumento da estabilidade aeróbica, de silagens de grãos úmidos de milho, observando no entanto, que houve aumento na concentração de etanol (de 0,43 para 0,91\% em média).

Existem outros aditivos para silagem que não serão aqui considerados, por não serem indicados como inibidores de leveduras, por apresentarem problemas quanto ao valor nutritivo das silagens com eles tratadas e/ou ainda, por resultarem em custo de aplicação elevado.

\subsection{Estabilidade aeróbica de silagens}

Driehuis et al. (1999) sintetizaram os aspectos envolvidos na conservação e deterioração das silagens, ressaltando que os fatores básicos para a preservação são a anaerobiose e o pH baixo, obtido com a fermentação predominantemente homolática. 
No entanto, durante o período de estocagem algum oxigênio penetra por difusão ou por dano físico do material usado na cobertura do silos, sendo que após a abertura a exposição da silagem ao oxigênio é inevitável e causa o crescimento de microrganismos aeróbicos facultativos que eventualmente causam a deterioração da silagem. Esses autores frisaram que o processo de deterioração aeróbica é iniciado por leveduras ácidotolerantes e, em silagens de milho, ocasionalmente por bactérias produtoras de ácido acético, sendo que, à medida que ocorre o processo de oxidação dos produtos da fermentação da silagem, o pH se eleva e outros microrganismos começam a proliferar. Os autores concluíram, chamando a atenção para o fato de que este processo resulta não só em perdas de componentes nutritivos da silagem, mas pode também comprometer sua qualidade higiênica, devido ao desenvolvimento de microrganismos patogênicos.

Ranjit \& Kung, Jr (2000) estudaram a deterioração aeróbica em silagem de milho e observaram, até o terceiro dia de exposição ao ar, perdas de 5,3\% da MS e 60\% dos carboidratos solúveis (3,4 vs $1,4 \%$ da MS) existentes no dia da abertura do silo. No mesmo período, o $\mathrm{pH}$ aumentou de 3,9 para 5,0 e os teores de ácido lático e acético foram reduzidos de 7,52 para $1,35 \%$ e de 1,88 para $0,08 \%$ da MS, respectivamente.

Estes pesquisadores notaram ainda que, o número de leveduras aumentou de aproximadamente $10^{6}$ para mais de $10^{8} \mathrm{ufc} / \mathrm{g}$ de silagem dentro de um dia e meio de exposição ao ar.

A estabilidade das silagens varia em função de diversos fatores, tendo sido relatado efeito significativo dos teores de MS, dos ácido acético e butírico e da contagem de leveduras, que apresentaram coeficientes de correlação de - 0,47 $0,44 \quad 0,36$ e 0,58, respectivamente (McDonald et al., 1991).

\subsection{Microflora epífita e qualidade de silagens}

Os microrganismos naturalmente presentes nas plantas forrageiras, chamados de microflora epífita, são responsáveis pela fermentação das silagens, afetando também a sua estabilidade aeróbica e a eficiência dos inoculantes microbianos . O número de microrganismos epífitas é variável, sendo afetado pelo tipo de forragem, pelo estádio de 
maturidade das plantas, pelo clima, pelo corte e condicionamento as forrageiras (Lin et al., 1992). Geralmente, os microrganismos existentes em maior número nas plantas forrageiras são as enterobactérias, as leveduras e os fungos, que competem com os lactobacilos pelos açúcares durante a ensilagem, sendo considerados indesejáveis (Bolsen et al., 1992). Além disso, a presença de leveduras é considerada prejudicial ao processo de ensilagem, porque estes microrganismos não contribuem para a acidificação, e estão associados com a deterioração aeróbica das silagens (Driehuis et al., 1999).

$\mathrm{Na}$ ensilagem da cana-de-açúcar ocorre extensa atividade de leveduras, podendo estar presentes na ordem de $10^{6} \mathrm{ufc} / \mathrm{g}$ de forragem, que convertem os carboidratos solúveis da forragem a etanol, $\mathrm{CO}_{2}$ e água, levando a perdas excessivas de $\mathrm{MS}$, a baixos teores de ácidos lático e acético e aumento no teor de FDA das silagens (Alli et al., 1983). Apesar de potencialmente aproveitável como substrato energético para os bovinos, através da conversão a acetato no rúmen (Chalupa et al., 1964), grande parte do etanol produzido nas silagens é perdido durante a estocagem nos silos (Alli et al., 1982). A produção deste álcool acarreta ainda, perda de aproximadamente 49\% de MS dos substratos, sendo que a reação bioquímica da sua síntese, catalisada pela via fermentativa de leveduras, pode ser descrita da seguinte forma (McDonald et al., 1991):

$$
\text { Glicose }+2 \mathrm{ADP}+2 \mathrm{Pi} \quad 2 \mathrm{Etanol}+2 \mathrm{CO}_{2}+2 \mathrm{ATP}+2 \mathrm{H}_{2} \mathrm{O}
$$

A produção de etanol resulta portanto em grande perda de MS da silagem, antes que esta seja fornecida aos animais e, embora tenham sido relatadas mudanças benéficas no padrão de fermentação ruminal, o valor nutritivo do etanol para ruminantes não está bem estabelecido. Chalupa et al. (1964), testando a dose de $9,7 \mathrm{~mL}$ de etanol/kg MS, conseguiram elevação de 6,6\% na digestibilidade da celulose em estudos in vitro, tendo sido considerado que isto foi devido ao aumento da energia prontamente disponível aos microrganismos, e aumento na concentração de ácido acético no rúmen de vacas fistuladas. Pradhan \& Hemken (1970) verificaram aumento na concentração dos ácidos graxos nvalérico e capróico, e redução do ácido propiônico, no líquido ruminal de vacas 
fistuladas suplementadas com 1300 a $1500 \mathrm{~mL}$ de etanol/dia via infusão contínua no rúmen (aproximadamente $120 \mathrm{~mL} / \mathrm{kg}$ de MS da dieta), juntamente com aumento no teor de gordura do leite, mas não detectaram efeito sobre o consumo de MS, a produção e o teor de sólidos não gordurosos do leite. Gould et al., (2001), embora tenham detectado aumento na DVIVMS em estudos in vitro, relataram que não houve efeito da suplementação com etanol, na dose de $6 \%$ da MS da dieta ingerida, sobre o consumo de MS e o ganho de peso de ovinos jovens. Nos três trabalhos dos pesquisadores mencionados neste parágrafo, foram citadas pesquisas anteriores onde a suplementação com etanol levou a resultados positivos sobre o ganho de peso de bovinos, mas as fontes não puderam ser acessadas.

O desenvolvimento das leveduras pode ser prolongado, e seu controle é dificultado, por não serem inibidas pelo $\mathrm{pH}$ normalmente encontrado nas silagens. Para a maioria das espécies o pH ótimo encontra-se entre 3,5 e 6,5, sendo que algumas espécies são capazes de sobreviver em pH igual ou inferior a 2 (McDonald et al., 1991).

Deve-se finalmente considerar que, sempre que houver penetração de ar nas silagens, as leveduras e os mofos, além de causarem a deterioração aeróbica e perdas no valor nutritivo da forragem, promovem a elevação do $\mathrm{pH}$, aumentando o risco de desenvolvimento de microrganismos patogênicos, como a Listeria monocytogenes (Rotz \& Muck, 1994).

Poucos trabalhos determinaram o efeito de aditivos sobre a contagem de leveduras em silagens de cana-de-açúcar, podendo ser citados os de González e McLeod (1976) e Alli et al. (1983) e raros são os que procuraram caracterizar a população epífita da cana, como o de López et al. (1988). Estudos neste sentido são necessários para que haja maior entendimento do modo de ação dos aditivos, que por sua vez, devem ser fundamentais para a obtenção de silagens de cana-de-açúcar de melhor qualidade. 


\section{DINÂMICA DA FERMENTAÇÃO, DAS PERDAS DE MATÉRIA SECA E DESENVOLVIMENTO DA MICROFLORA EPÍFITA EM SILAGEM DE CANA-DE-AÇÚCAR}

\section{Resumo}

O objetivo deste trabalho foi estudar a dinâmica da fermentação, das perdas de matéria seca (MS) e de valor nutritivo e do desenvolvimento da microflora epífita, na ensilagem da cana-de-açúcar. A cana-de-açúcar (RB83-5486) foi colhida manualmente aos 12 meses de crescimento ( $23^{\circ}$ brix), picada sem a retirada da palha em uma picadora de forragens modelo estacionário, e ensilada em baldes de plástico de 20 litros adaptados com válvulas para eliminação de gases, e substrato para colheita de efluentes. Os minisilos foram mantidos sob temperatura ambiente e amostrados após 1/2, 1, 2, 3, 7, 15, 45, 90, 120 e 180 dias de fermentação. As perdas de MS total, de efluentes e gases, foram avaliadas por gravimetria. O teor de etanol atingiu nível máximo (6,4\% da MS) aos 15 dias após a ensilagem, correspondendo ao consumo de $68 \%$ dos carboidratos solúveis (CHOs) da forragem, e foi acompanhado pelo intenso desenvolvimento de leveduras $(5,05 \mathrm{log} \mathrm{ufc} / \mathrm{g})$. Aos 45 dias de ensilagem atingiu-se a maior perda total de MS (29,2\% da MS) e de perdas gasosas (15,8\% da MS). Houve pequena produção de efluentes durante todo o período, totalizando 20,1 kg/t MV. O pH da silagem apresentou queda constante atingindo 3,47 aos 180 dias. O teor de MS da forragem foi reduzido de aproximadamente $35 \%$, na ensilagem, para $26 \%$ na amostragem do $45^{\circ}$ dia. A expressiva produção de etanol, caracterizada por perda elevada de CHOs e aumento no teor de fibra, levou à redução de 25\% da DVIVMS da forragem ensilada (63 para 47\%). 


\section{FERMENTATION AND EPIPHYTIC MICROFLORA DYNAMICS IN SUGAR CANE SILAGE}

\section{Summary}

The main objective of this trial was to study the fermentation pattern with focus on dry matter (DM) and nutritional losses and epiphytic microflora dynamics during ensilage of sugar cane. Mature sugar cane variety RB83-5486 (12 months of vegetative growths) was hand harvested, processed in a stationary chopper and ensiled in $20 \mathrm{~L}$ plastic buckets provided with valves for gases release and a device for effluent collection. Laboratory silos were kept under ambient temperature and sampled at, $1 / \mathbf{2}$, 2, 3, 7, 15, 45, 90, 120 and 180 days after sealing. Total DM, gases and effluent losses were evaluated through gravimetry. Ethanol yield was maximum after 15 days from sealing (6.4\% in DM), followed by $68 \%$ soluble carbohydrates (CHOs) disappearance and intensive growth of yeasts. Gases (16\% of DM) and total DM (29\%) losses reached a plateau 45 days after ensilage. Effluent yield was negligible $(20 \mathrm{~kg} / \mathrm{t})$. Silage $\mathrm{pH}$ was lowest on day $180(3,47)$. Silage DM content decreased (35 to 26\%) from day 0 to day 45 from sealing. The increase in the ethanol yield showed na opposite trend to the lowering on the CHOs pool and decreased IVDDM due to the increase in the fiber fraction content in the silage.

\subsection{Introdução}

A cana-de-açúcar é espécie forrageira de maior potencial de produção de MS e energia por unidade de área, produzindo em um único corte de 15 a 20t de NDT, sendo tradicionalmente fornecida fresca aos rebanhos bovinos, pois tem a capacidade de manter seu valor nutritivo durante os vários meses do período da seca, época quando é normalmente utilizada. Atualmente no entanto, tem-se realizado a ensilagem desta planta forrageira, na tentativa de melhorar a eficiência da colheita, de facilitar o manejo dos canaviais e como forma de viabilizar o uso da cana-de-açúcar fora do período da safra, ou ainda na ocorrência de fogo e geadas, para evitar a perda da forragem. 
Entretanto, a ensilagem da cana-de-açúcar sem aditivos, leva à fermentação alcoólica, com perdas acentuadas no valor nutritivo e de matéria seca das silagens. Em trabalhos pioneiros na década de 1970 já se constatou perda de valor nutritivo da cana ensilada, com grande redução no conteúdo total dos açúcares e teor alcoólico de 5,5\% da MS (Preston et al., 1976). Estudos da dinâmica da fermentação em silagens de cana-deaçúcar indicaram que, durante os 10 primeiros dias após o fechamento dos silos, a silagem pode perder até $90 \%$ dos carboidratos solúveis originalmente presentes na cana fresca, apresentar elevação de $44 \%$ no teor de fibra em detergente ácido e atingir teor de etanol de 8,9\% na MS (Alli et al., 1982). O efeito benéfico do amadurecimento, sobre o valor nutritivo da cana-de-açúcar (Boin \& Tedeschi, 1993), pode ser neutralizado com a ensilagem. Kung, Jr. \& Stanley (1982) constataram produção crescente de álcool em silagens de cana-de-açúcar ensiladas com seis, nove e 12 meses de crescimento (7,5 9,5 e $15,5 \%$ de etanol na MS, respectivamente), com conseqüente diminuição da energia bruta da forragem.

São poucos os trabalhos de pesquisa realizados no Brasil que forneceram dados para a caracterização do processo fermentativo e de perdas em silagens de cana-deaçúcar. Andrade et al. (2001) relataram 7,8\% de etanol e coeficiente de digestibilidade aparente de $54 \%$ da MS, para silagens produzidas com cana-de-açúcar colhida aos sete meses de crescimento. Coan et al. (2002) avaliando a composição química de cana-deaçúcar madura (12 meses de rebrota) ensilada em microsilos de PVC, durante 55 dias, relataram diminuição no teor de MS, aumento nos constituintes da parede celular, com maiores concentrações de FDN, FDA e lignina, e aumento no teor de PB da silagem em relação à cana fresca. $\mathrm{O}$ padrão de fermentação de silagens de cana-de-açúcar, ensilada após 12 meses de crescimento (primeiro corte) em microsilos de PVC, foi estudado por Molina et al. (2002), através da amostragem das silagens com 1, 3, 5, 7, 14, 28 e 56 dias de conservação. Detectou-se redução no teor de MS da silagem entre o primeiro e o último dia considerados, porém não houve diferença para os valores de $\mathrm{pH}$ e $\mathrm{PB}$. Bernardes et al. (2002) constataram teor de 6,9\% de etanol na MS da silagem, para canade-açúcar ensilada aos 12 meses de crescimento. 
O objetivo deste estudo foi fornecer um conjunto mais abrangente de informações sobre as mudanças que ocorrem com a forragem durante a ensilagem da cana-de-açúcar, estudando a dinâmica da fermentação e das perdas na ensilagem de uma variedade de cana de uso agrícola e industrial, estabelecendo a variação temporal da concentração dos componentes químicos, da digestibilidade verdadeira "in vitro", das perdas de MS e de desenvolvimento da microflora epífita.

\subsection{Material e Métodos}

O corte e a ensilagem da cana-de-açúcar foram realizados no dia 20 de agosto de 2000, após aproximadamente 12 meses de crescimento ( $1^{\mathrm{o}}$ corte). $\mathrm{O}$ valor do grau brix da forrageira foi determinado através de um refratômetro de campo (marca TOKYO ${ }^{\circledR}$, modelo 032) indicando valor médio de $23,1^{\circ}$. A cana foi colhida manualmente e picada, sem a retirada da palha, através de uma picadora de forragens modelo estacionário, regulada para corte com tamanho de partícula médio de $10 \mathrm{~mm}$.

A variedade industrial de cana-de-açúcar (RB83-5486), foi fornecida pela Faculdade de Agronomia da Universidade Federal de São Carlos (UFSCAR), Campus de Araras, SP, onde foi processada e ensilada em silos laboratoriais. Após a ensilagem, os microsilos foram transportados para o Setor de Ruminantes do Departamento de Zootecnia da ESALQ, em Piracicaba, SP, onde permaneceram em local coberto, sob temperatura ambiente, até o momento da abertura.

\subsubsection{Silos experimentais e produção das silagens}

Como silos experimentais (unidades experimentais) foram utilizados baldes de plástico de 20 litros (minisilos), com tampas próprias à ved ação e adaptadas com válvulas do tipo Bunsen, para que fosse possível o escape de gases e a avaliação das perdas gasosas durante a ensilagem. No fundo de cada balde foram colocados dois quilos de areia seca, separados da silagem por tela fina de plástico e duas camadas de tecido fino de algodão, com vista àavaliação quantitativa de efluentes. 
A ensilagem foi realizada, compactando-se com os pés camadas de 5 a $10 \mathrm{~cm}$ de espessura da cana-de-açúcar picada, buscando atingir a maior quantidade possível de forragem em cada balde, para uniformização da densidade das silagens entre os silos. Aproximadamente $9 \mathrm{~kg}$ de forragem foram ensilados em cada balde, resultando em densidade aproximada de $500 \mathrm{~kg} / \mathrm{m}^{3}$ na silagem, levando-se em conta o volume do balde que foi preenchido com areia.

Após o enchimento, os minisilos foram fechados com as tampas apropriadas e pesados. Após a pesagem as tampas foram vedadas com fita plástica auto-adesiva, para impedimento da entrada de ar.

\subsubsection{Avaliação das perdas e amostragem das silagens}

Os baldes foram pesados antes da ensilagem, com a tampa e contendo o aparato para colheita de efluentes, para que fosse possível o cálculo do peso líquido da forragem contida em cada silo experimental e, posteriormente, dos efluentes.

As silagens foram amostradas, e os minisilos foram novamente pesados, aos 1/2, 1, 2, 3, 7, 15, 45, 90, 120 e 180 dias após o enchimento dos silos, sendo que, as datas de abertura foram estabelecidas de forma que fosse possível determinar a variação temporal dos parâmetros avaliados nas silagens.

Em cada dia de amostragem procedeu-se à retirada das fitas adesivas e pesagem dos minisilos antes da abertura, após o que realizava-se a tomada de amostras de silagem, retirada da forragem dos baldes e pesagem dos mesmos contendo apenas o aparato de recepção de efluentes.

Cada amostra de silagem foi composta por duas a três porções retiradas da parte central da massa de forragem contida em cada silo. As amostras destinadas à determinação do $\mathrm{pH}$, dos teores de etanol e carboidratos solúveis em água, foram colocadas em sacos de plástico e estocadas em congelador $\left(-5^{\circ} \mathrm{C}\right)$ e as amostras utilizadas para as demais análises bromatológicas foram colocadas em sacos de papel e secas em estufa com ventilação forçada a $60^{\circ} \mathrm{C}$ por $48 \mathrm{~h}$. 
A perda de matéria seca na forma de gases foi calculada pela diferença entre o peso bruto inicial e final dos minisilos e a quantidade de efluentes pela diferença entre o peso inicial e final dos baldes contendo apenas a areia, a tela plástica e o tecido de algodão. A perda total de matéria seca das silagens, foi calculada pela diferença entre o peso da matéria seca da forragem inicialmente colocada em cada minisilo e o peso da matéria seca da silagem no dia da abertura.

\subsubsection{Análises químico-bromatológicas}

As amostras secas de silagem foram moídas contra peneira de malha de $1 \mathrm{~mm}$ e posteriormente analisadas pelo método da espectroscopia de reflectância de infravermelho proximal (NIRS) (Berzaghi et al., 1997; Cozzolino et al., 2001) utilizando-se um espectrofotômetro modelo NIRS $5000^{\circledR}$ (NIRSystems, Silver Spring, MD, USA). A análise utilizou comprimentos de onda entre 700 e $2100 \mathrm{~nm}$ e os espectros das amostras "escaneadas" foram armazenados em curvas log (1/R) em intervalos de 2nm. O método de seleção existente no "software" do equipamento identificou as amostras distantes mais de $3 \mathrm{H}$ (distância padronizada de Mahalanobis) da média, "outliers", que foram excluídas. Adotando-se uma distância mínima de 0,6 H entre

amostras (Shenk \& Westerhaus, 1991), foram selecionadas as que deveriam ser analisadas pelos métodos da bromatologia convencional. De posse dos resultados destas análises, o programa do equipamento NIRS foi capaz de inferir a composição química e bromatológica das demais amostras.

As análises das amostras selecionadas pelo método NIRS foram realizadas como segue:

- matéria seca em estufa a $105^{\circ} \mathrm{C}$ por 8 horas.

- a matéria mineral (cinzas) foi obtida pela incineração das amostras em mufla a $600{ }^{\circ} \mathrm{C}$ por 3 horas.

- os teores de fibra em detergente neutro (FDN) e a digestibilidade verdadeira "in vitro" matéria seca (DVIVMS) foram determinados através do método ANKON $^{\circledR}$ Fiber Analyser (ANKON Technology Corporation, Fairport, NY). 
- os teores de fibra em detergente ácido (FDA) e de lignina (LIG) foram avaliados egundo os métodos propostos por Van Soest et al. (1985) e a proteína bruta (PB) segundo AOAC (1990).

- o teor de PB para o tratamento com uréia foi determinado pelo método macro Kjeldahl (AOAC, 1990), em amostras úmidas de silagem que haviam sido mantidas congeladas $\left(-5^{\circ} \mathrm{C}\right)$.

Os teores de etanol e de CHOs foram determinados em extratos aquosos das amostras de silagem, obtidos segundo método descrito por Kung, Jr. (1996). Para isto, $25 \mathrm{~g}$ de amostra úmida foram processados com $225 \mathrm{~mL}$ de água destilada, em liquidificador, durante um minuto. Em seguida, o material foi filtrado em papel de filtro Whatman ${ }^{\circledR} 54$, acidificado com $\mathrm{H}_{2} \mathrm{SO}_{4}$ a $50 \%$ e centrifugado, sendo o extrato líquido armazenado em congelador $\left(-5^{\circ} \mathrm{C}\right)$ até o momento das análises. $\mathrm{O} \mathrm{pH}$ foi determinado nos extratos, antes da filtragem, através de um potenciômetro digital da marca Digimed $^{\circledR}$, modelo DM 20. As análises do teor de etanol foram realizadas nos laboratórios do Setor de Açúcar e Álcool do Departamento de Agroindústria Alimentos e Nutrição da ESALQ/USP de Piracicaba, por meio de cromatógrafo a gases com detector de ionização de chama, marca Gregório e Cioli ${ }^{\circledR}$, modelo CG-37D. As determinações dos teores de CHOs foram realizadas pelo método colorimétrico de Dubois et al. (1956), diluindo-se os extratos aquosos das amostras de silagens, na proporção de $1 \mathrm{~mL}$ de extrato para $20 \mathrm{~mL}$ de água destilada.

\subsubsection{Caracterização da microflora epífita}

Amostras da cana-de-açúcar foram tomadas antes da ensilagem, e das silagens nos dias de abertura dos silos experimentais, para contagem de bactérias produtoras de ácido lático e leveduras presentes na forragem. As amostras (aproximadamente $25 \mathrm{~g}$ ) foram colocadas em sacos de plástico e mantidas resfriadas em caixas de poliestireno ("isopor") contendo bolsas de gelo, sendo em seguida encaminhadas para análise, no Laboratório de Genética de Leveduras do Departamento de Genética da ESALQ/USP de Piracicaba, onde foram processadas no mesmo dia. 
O isolamento e a contagem dos microrganismos foi realizada utilizando-se "plaqueamento" em meio seletivo, segundo método descrito por Lin et al. (1992). Amostras das forragens $(50 \mathrm{~g})$ foram pesadas em recipientes esterilizados contendo 450 $\mathrm{mL}$ de fosfato de potássio dibásico $0,7 \mathrm{mM}$ (tampão, $\mathrm{pH}$ 7,0) e homogeneizadas por 40 s. Diluições em série ( $\mathrm{x}$ 10) foram realizadas com a solução tamponada e os microrganismos foram isolados posteriormente com o uso dos respectivos meios de cultura seletivos (Seale et al., 1986), como segue:

- Bactérias produtoras de ácido láctico: Rogosa SL agar (Difco Laboratories, Detroit, MI) foi utilizado para contagem do grupo contendo Lactobacilos, Pediococos e Leuconostocs. Streptococos foram contados em meio Slanetz and Bartley (Oxoid Ltd., Hampshire, England). As contagens foram realizadas após incubação das placas por dois dias a $35^{\circ} \mathrm{C}$.

- Leveduras: Malt agar (Difco) com adição de ampicilina (200 $\mu \mathrm{g} / \mathrm{mL})$ e tetraciclina $(200 \mu \mathrm{g} / \mathrm{mL})$ para inibição do crescimento de bactérias. A contagem foi realizada após dois dias de incubação a $25^{\circ} \mathrm{C}$.

\subsubsection{Análise estatística}

O delineamento experimental utilizado foi o inteiramente casualizado, com quatro repetições e as seguintes datas de abertura: 1/2, 1, 2, 3, 7, 15, 45, 90, 120 e 180 dias.

O modelo proposto foi analisado pelo PROC GLM do programa SAS (SAS, 1988) e as comparações das médias obtidas nas datas de abertura foram realizadas utilizando-se o método dos quadrados mínimos (LSMEANS). Foram declaradas significativas as diferenças entre médias a partir de $\mathrm{P}<0,05$.

Com o objetivo de identificar as relações funcionais entre as variáveis, recorreuse ao PROC CORR do programa SAS (SAS, 1998), com vistas à análise de correlação simples. 


\subsection{Resultados e Discussão}

A cana-de-açúcar utilizada para a ensilagem apresentou teores elevados de MS e de carboidratos solúveis (Tabela 1) em relação à média dos valores relatados em trabalhos de pesquisa sobre ensilagem no Brasil, onde foram encontrados valores ao redor de 27\% de MS e 17,8\% de CHOs (Coan et al., 2002; Bernardes et al., 2002). Alguns trabalhos realizados no exterior indicam valores mais altos, como 52\% de CHOs na MS para cana-de-açúcar colhida aos 7,5 meses de crescimento (Alli \& Baker, 1982) ou 34\% de CHOs para cana colhida aos 16,5 meses, contendo 37\% de MS (Alli et al., 1983). Os teores médios de FDN, FDA, lignina e PB obtidos no presente experimento, estão dentro da amplitude apresentada pelos dados da literatura na área de interesse.

A silagem apresentou tendência de aumento numérico, porém não significativo ( $\mathrm{P}>0,05)$, na concentração de etanol, até o $3^{\circ}$ dia de ensilagem (Tabela 1). A partir desse ponto a concentração do álcool aumentou de forma constante até o $15^{\circ}$ dia, quando atingiu o nível de mais alto $(\mathrm{P}<0,05)$. A concentração do álcool manteve-se então constante do $15^{\circ}$ ao $120^{\circ}$ dia, mas sofreu redução de $50 \%(\mathrm{P}<0,05)$ entre este ponto e o $180^{\circ}$ dia de estocagem, o que deve ter ocorrido devido à perda por volatilização, já que os minisilos foram equipados com válvulas para escape de gases.

A tendência de variação da concentração de carboidratos solúveis (CHOs) na silagem, evidencia o comportamento oposto da concentração dos açúcares em relação à do etanol (Figura 1). Houve o consumo intenso dos açúcares até o $15^{\circ}$ dia de ensilagem, totalizando o desaparecimento de aproximadamente $68 \%$ dos carboidratos presentes no início da ensilagem, sendo que a partir desse ponto a concentração de CHOs manteve-se constante até os 180 dias de estocagem $(\mathrm{P}<0,05)$ (Tabela 1$)$.

Com base na concentração de nutrientes contidos na silagem (Tabela 1) pode-se inferir que, para cada $100 \mathrm{~g}$ de forragem ensilada existiam aproximadamente $24 \mathrm{~g}$ de CHOs (24\% - média dos dois primeiros dias) e que, aos 15 dias de estocagem foram recuperados 9,0g desses nutrientes $(9,02 \%$ da MS) e 6,4g de etanol (6,39\% da MS). Considerando-se que para cada mol de hexose fermentada (180 g/mol) são produzidos 2 moles de etanol (46 g/mol), ou seja, a massa de etanol produzida durante a 
fermentação alcoólica pelas leveduras corresponde a 50\% da massa dos açúcares consumidos no processo, sendo o restante transformado em $\mathrm{CO}_{2}$ e água (McDonald et al., 1991), conclui-se que, a quantidade de etanol existente aos 15 dias de ensilagem correspondeu ao consumo de aproximadamente $85 \%$ da quantidade de CHOs desaparecidos durante o período de conservação (15g). Devendo-se ressaltar que foi considerada nos cálculos, apenas a via de produção de etanol na fermentação por leveduras, sem levar em conta a possível produção de álcool por bactérias heteroláticas.

A silagem neste experimento apresentou fermentação alcoólica menos intensa do que a reportada por Alli \& Baker (1982). Esses autores, ao estudar a dinâmica da fermentação, em silagem de cana contendo inicialmente $28 \%$ de MS com $52 \%$ de CHOs, verificaram estabilização no teor de etanol em $9 \%$ da MS no sexto dia de ensilagem, quando a silagem apresentou $23 \%$ de MS com 5\% de CHOs, aproximadamente. A concentração de etanol (Tabela 1), no entanto, atingiu valor próximo ao relatado por Bernardes et al. (2002) que detectaram concentração aproximada de etanol de 7\% na MS, após 55 dias de ensilagem de cana-de-açúcar, colhida aos 12 meses de crescimento e contendo $20 \%$ MS.

Resultados semelhantes aos deste trabalho foram relatados Alli et al. (1983) que, utilizando cana-de-açúcar com características mais próximas às da cana utilizada neste experimento (37\% de MS e 34\% de CHOs), ensilada em tambores de 205 litros, obtiveram aumento na concentração de etanol e desaparecimento de CHOs até o $21^{\circ}$ dia de ensilagem, quando a concentração de etanol se estabilizou em valores próximos a $9 \%$ e a de CHOs em 1,3\% da MS, para silagem com 33\% de MS.

A perda de MS na forma de gases ocorreu até os 45 dias de estocagem da silagem, sendo que entre o $45^{\circ}$ e o $180^{\circ}$ dia não houve acréscimo $(\mathrm{P}<0,05)$, com os valores máximos indicando perdas gasosas correspondentes a $15 \%$ da MS. A perda total de MS também estabilizou-se a partir dos 45 dias, atingindo em média $30 \%$ da MS 
Tabela 1. Composição bromatológica e perdas de MS da silagem de cana-de-açúcar, nos diversos períodos após a ensilagem.

\begin{tabular}{|c|c|c|c|c|c|c|c|c|c|c|c|c|c|c|}
\hline \multirow[t]{2}{*}{ Variável } & \multicolumn{11}{|c|}{ Dias após ensilagem } & \multirow[t]{2}{*}{ Média } & \multirow[t]{2}{*}{$E P M$} & \multirow[t]{2}{*}{ Efeito } \\
\hline & 0 & $1 / 2$ & 1 & 2 & 3 & 7 & 15 & 45 & 90 & 120 & 180 & & & \\
\hline Etanol (\% MS) & nd & $1,18^{\mathrm{c}}$ & $0,68^{\mathrm{c}}$ & $0,77^{\mathrm{c}}$ & $1,33^{\mathrm{c}}$ & $3,13^{b}$ & $6,39^{a}$ & $7,92^{a}$ & $6,81^{a}$ & $6,12^{a}$ & $3,52^{b}$ & 3,60 & 0,48 & $* *$ \\
\hline CHOs (\% MS) & nd & $23,0^{\mathrm{ab}}$ & $26,1^{a}$ & $23,8^{a b}$ & $22,6^{\mathrm{b}}$ & $16,7^{\mathrm{c}}$ & $9,02^{d}$ & $6,83^{d}$ & $6,25^{\mathrm{d}}$ & $5,98^{d}$ & $6,41^{d}$ & 15,0 & 1,19 & $* *$ \\
\hline Perda gases (\% MS) & $0,00^{\mathrm{f}}$ & $0,53^{\text {ef }}$ & $0,64^{\text {ef }}$ & $1,25^{\mathrm{e}}$ & $2,37^{\mathrm{d}}$ & $8,06^{\mathrm{c}}$ & $13,5^{b}$ & $15,8^{\mathrm{a}}$ & $15,0^{\text {a }}$ & $15,2^{\mathrm{a}}$ & $15,0^{\mathrm{a}}$ & 8,15 & 0,33 & $* *$ \\
\hline Efluente (kg/t MV) & $0,00^{\mathrm{e}}$ & $1,40^{\text {de }}$ & $1,26^{\mathrm{de}}$ & $1,40^{\mathrm{de}}$ & 1,55 de & $2,09 \mathrm{de}$ & $3,62^{d}$ & $7,41^{\mathrm{c}}$ & $13,3^{b}$ & $15,7^{\mathrm{b}}$ & $20,1^{\text {a }}$ & 6,13 & 0,84 & $* *$ \\
\hline Perda total (\% MS) & $0,00^{\mathrm{f}}$ & $1,76^{\mathrm{f}}$ & $2,50^{\mathrm{f}}$ & $4,42^{e f}$ & $5,17^{\mathrm{e}}$ & $14,6^{\mathrm{d}}$ & $25,2^{\mathrm{c}}$ & $29,2^{a b}$ & $31,2^{a}$ & $28,1^{\mathrm{b}}$ & $31,4^{\mathrm{a}}$ & 16,18 & 0,9 & $* *$ \\
\hline DVIVMS (\% MS) & $62,9^{\mathrm{a}}$ & $61,2^{a b}$ & $60,9^{b}$ & $60,4^{b}$ & $59,9^{\mathrm{b}}$ & $55,0^{\mathrm{c}}$ & $49,5^{d}$ & $47,1^{\mathrm{e}}$ & 47,2 ef & 47,0 ef & $45,4^{\mathrm{f}}$ & 54,0 & 0,54 & $* *$ \\
\hline $\operatorname{MS}(\%)$ & $34,5^{\mathrm{a}}$ & $34,0^{\mathrm{a}}$ & $33,8^{a b}$ & $33,2^{b}$ & $33,0^{\mathrm{b}}$ & $30,4^{\mathrm{c}}$ & $27,2^{\mathrm{d}}$ & $26,1^{\mathrm{e}}$ & $25,4^{\mathrm{e}}$ & $26,6^{\text {de }}$ & $25,5^{\mathrm{e}}$ & 29,8 & 0,31 & $* *$ \\
\hline FDN (\% MS) & $49,6^{\mathrm{e}}$ & $52,3^{\mathrm{de}}$ & $53,1^{d}$ & $54,3^{\mathrm{d}}$ & $54,6^{\mathrm{d}}$ & $60,6^{c}$ & $58,9^{\mathrm{b}}$ & $70,7^{a b}$ & $70,3^{a b}$ & $70,6^{\mathrm{ab}}$ & $72,9^{\mathrm{a}}$ & 61,9 & 0,84 & $* *$ \\
\hline FDA (\% MS) & $32,5^{\mathrm{e}}$ & $33,8^{\mathrm{e}}$ & 34,3 de & $35,3^{d}$ & $35,6^{\mathrm{d}}$ & $39,0^{\mathrm{c}}$ & $43,4^{b}$ & $45,0^{\mathrm{a}}$ & $44,6^{\mathrm{ab}}$ & $44,7^{\mathrm{ab}}$ & $45,8^{\mathrm{a}}$ & 39,6 & 0,46 & $* *$ \\
\hline Lignina (\% MS) & $4,57^{\mathrm{d}}$ & $4,59^{\mathrm{d}}$ & $4,68^{\mathrm{d}}$ & $4,77^{\mathrm{d}}$ & $4,77^{\mathrm{d}}$ & $5,38^{\mathrm{c}}$ & $6,03^{b}$ & $6,62^{a}$ & $6,63^{\mathrm{a}}$ & $6,63^{a}$ & $6,75^{a}$ & 5,60 & 0,08 & $* *$ \\
\hline $\mathrm{PB}(\% \mathrm{MS})$ & $2,04^{\mathrm{cd}}$ & $1,80^{\mathrm{cd}}$ & $1,62^{\mathrm{d}}$ & $1,55^{\mathrm{d}}$ & $1,68^{\mathrm{d}}$ & $2,13^{\mathrm{c}}$ & $2,52^{b}$ & $2,82^{b}$ & $2,89^{\mathrm{b}}$ & $3,07^{\mathrm{ab}}$ & $3,36^{\mathrm{a}}$ & 2,30 & 0,13 & $* *$ \\
\hline Cinzas (\% MS) & $2,44^{\mathrm{c}}$ & $3,04^{b}$ & $2,83^{b c}$ & $2,50^{\mathrm{c}}$ & $2,78^{b c}$ & $3,05^{\mathrm{b}}$ & $4,01^{\mathrm{a}}$ & $4,15^{\mathrm{a}}$ & $4,19^{\mathrm{a}}$ & $4,23^{\mathrm{a}}$ & $4,24^{\mathrm{a}}$ & 3,43 & 0,13 & $* *$ \\
\hline $\mathrm{pH}$ & nd & $5,28^{a}$ & $4,57^{\mathrm{b}}$ & $4,08^{\mathrm{c}}$ & $3,90^{\mathrm{d}}$ & $3,78^{\mathrm{e}}$ & $3,73^{\mathrm{e}}$ & $3,60^{f}$ & $3,53^{\mathrm{fg}}$ & $3,50^{\mathrm{fg}}$ & $3,47^{\mathrm{g}}$ & 3,96 & 0,04 & $* *$ \\
\hline
\end{tabular}

nd = não determinado $; \mathrm{PB}=$ proteína bruta; FDN = fibra em detergente neutro; FDA = fibra em detergente ácido; CHOs = carboidratos solúveis em água; DVIVMS = digestibilidade verdadeira in vitro da MS; MS = matéria seca; MV= massa verde 
total da silagem, e mantendo-se constante até os 180 dias após a ensilagem (Tabela 1).

A quantidade de efluente produzida foi pequena (Tabela 1) e compatível com o teor médio de matéria seca da silagem durante todo o período, que foi de $26 \%$ (média ponderada), de acordo com dados de McDonald et al. (1991). A quantidade de efluente foi crescente até os 180 dias de conservação $(\mathrm{P}<0,05)$, no entanto, a taxa de acúmulo do efluente, que se manteve praticamente constante nos primeiros 90 dias da ensilagem em valores médios de $0,14 \mathrm{~kg} / \mathrm{t} /$ dia, reduziu-se para $0,07 \mathrm{~kg} / \mathrm{t} / \mathrm{dia}$, entre 90 e 180 dias de conservação da silagem.

Ao considerar que a perda total de MS e a perda por gases não sofreram mudança entre o $45^{\circ}$ e o $180^{\circ}$ dia, concluise que, apesar da perda contínua de água pelo efluente, a perda de MS nesta forma foi insignificante após os 45 dias de conservação da silagem (Figura 2). Ao adotar-se o teor médio de MS no efluente como 5\% (McDonald et al., 1991) pode-se inferir que, os $7,41 \mathrm{~kg}$ de efluentes produzidos para cada tonelada de forragem ensilada, até o $45^{\circ}$ dia carrearam $0,37 \mathrm{~kg}$ de $\mathrm{MS}$ por tonelada de forragem, correspondendo a $0,12 \%$ da MS originalmente presente na forragem $(345 \mathrm{~kg} / \mathrm{t})$, o que caracteriza a reduzida importância dessa fonte de perda, neste caso.

Levando-se em conta a perda total de MS e a produção de efluentes descritas na Tabela 1 pode-se calcular que, para cada quilograma de forragem fresca ensilada, seriam encontrados aos 45 dias após a ensilagem 244,3 g de MS e 648,0 g de água, considerando-se 5\% de MS no efluente (valor hipotético), o que resultaria em uma silagem com 27,4\% de MS. Levando-se em conta que o teor de MS real da silagem foi de $26,1 \%$, deduz-se que houve a geração de $43,7 \mathrm{~g}$ de água para cada $\mathrm{kg}$ de forragem ensilada, advinda do metabolismo de compostos nutritivos pelos microrganismos, correspondendo ao consumo de $12,7 \%$ da MS original da forragem. Pode-se assim concluir que, do total da perda de MS no período de 45 dias (29,2\%), 15,8 unidades percentuais foram devido à perda por gases, 12,7 unidades devido à geração de ág ua durante a fermentação e 0,1 unidades devido à lixiviação via efluente. A diferença de 0,6\%, necessária para totalizar o valor de 29,2\% de perdas de MS encontrado, podendo ser atribuída aos pequenos erros inerentes às avaliações das amostras e aos desvios causados pelos valores hipotéticos assumidos. 


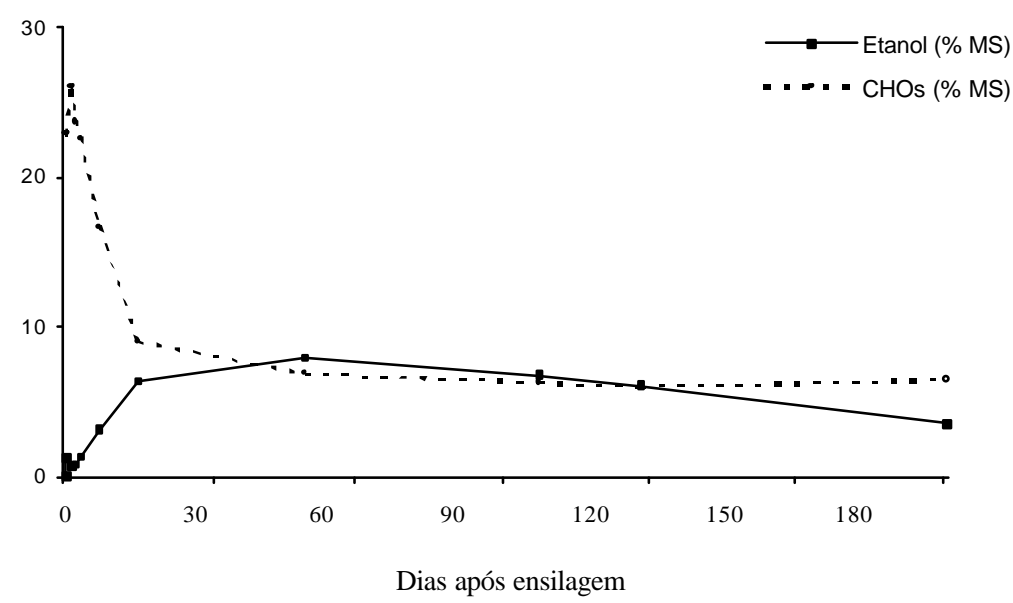

Figura 1 - Evolução temporal da concentração de etanol e de carboidratos solúveis em água (CHOs) na silagem de cana-de-açúcar

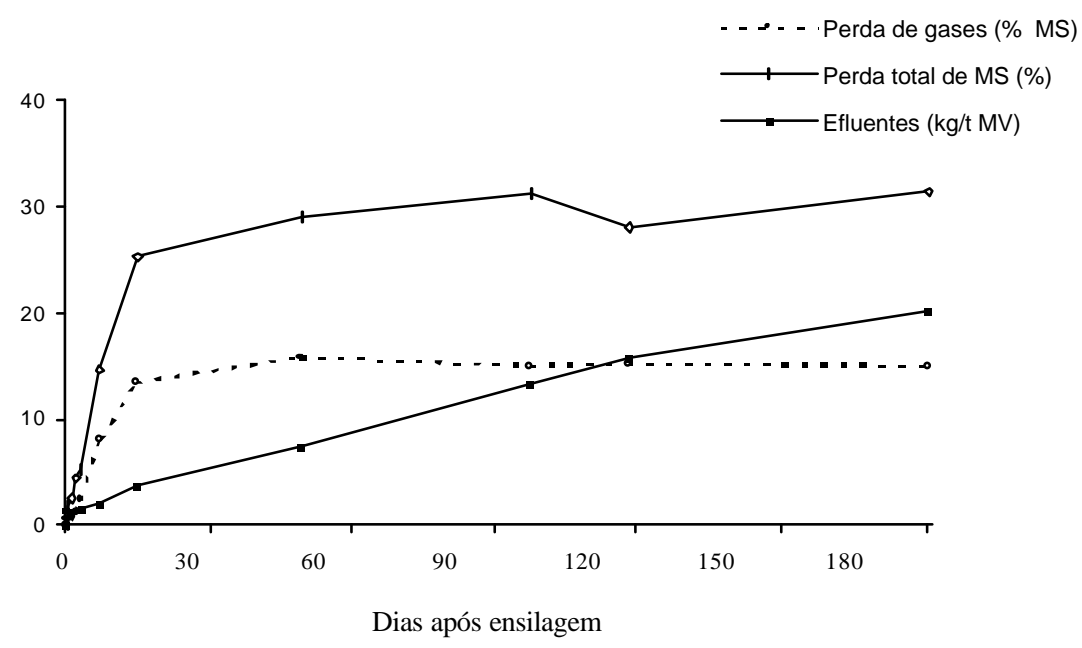

Figura 2 - Evolução temporal da perda de gases, da perda total de MS e da produção de efluentes da silagem de cana-de-açúcar 


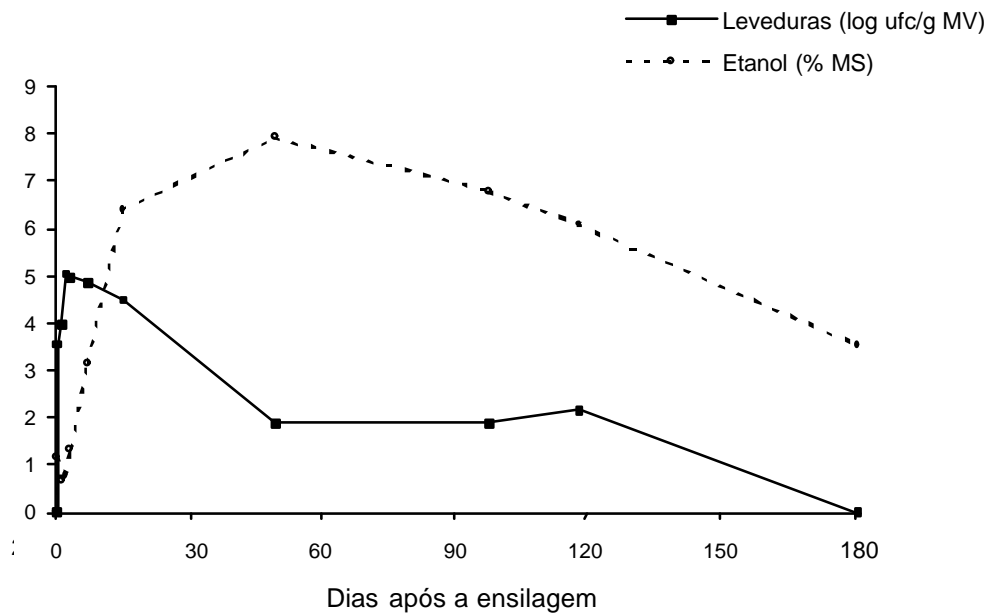

Figura 3 - Evolução temporal da população de leveduras (expressa como logaritmo do número de unidades formadoras de colônia por grama massa verde - log ufc/g de MV) e do teor de etanol da silagem de cana-de-açúcar

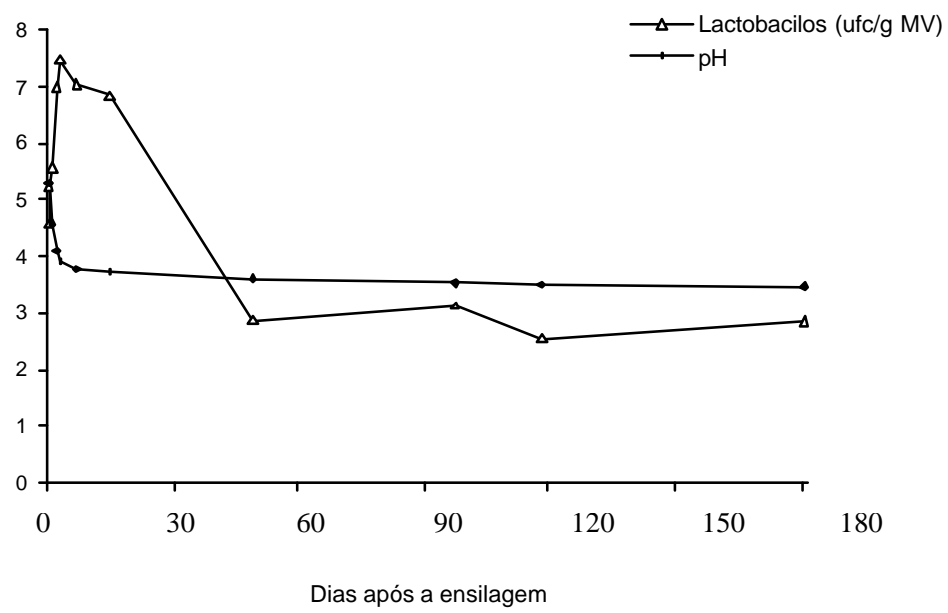

Figura 4 - Evolução temporal da população de bactérias homolácticas (expressa como logaritmo do número de unidades formadoras de colônia por grama de massa verde - log ufc/g de MV), e do pH da silagem de cana-de-açúcar 
Na Tabela 1 observa-se que no sétimo dia após o fechamento dos silos o pH atingiu nível suficientemente baixo para inibir o desenvolvimento bacteriano (Rotz \& Muck, 1994), sendo possível assumir que a perda de MS até o $45^{\circ}$ dia ocorreu principalmente devido à ação das leveduras que, no caso das espécies mais comuns em silagens, têm pH ótimo para desenvolvimento entre 3,5 e 6,5 (McDonald et al., 1991). A partir de 45 dias de estocagem, a ausência de perdas por gases indica que, a população de microrganismos presentes na silagem deve ter atingido taxas mínimas de crescimento, ou mesmo que o crescimento cessou.

Considera-se como um dos princípios básicos da ensilagem, que a inibição do desenvolvimento dos microrganismos da silagem ocorre pelo abaixamento do $\mathrm{pH}$ ou exaustão dos substratos (Rotz \& Muck, 1994). Levando-se em conta que o pH da silagem neste experimento não foi baixo o suficiente para inibição de leveduras, e que não houve exaustão dos CHOs (substrato), pode-se levantar a hipótese de que o etanol tenha sido o responsável pela "estabilização" da silagem, levando-se em conta que as leveduras podem ser inibidas pelo aumento da concentração de etanol, que afeta a atividade de enzimas glicolíticas, como a descarboxilase pirúvica (Gutierrez et al, 1991). Existem evidências de que a concentração de etanol neste caso, que atingiu 2,3\% na fase líquida da silagem aos 45 dias de estocagem, pode ser suficiente para a inibição do desenvolvimento das leveduras. Driehuis \& Wikselaar (2000) avaliaram a concentração de etanol em um grande número de silagens de capim emurchecido, totalizando 21 silagens produzidas em laboratório e 36 silagens produzidas em fazendas, tendo constatado que $19 \%$ das silagens de laboratório e $29 \%$ das silagens das fazendas apresentaram predomínio da produção de etanol (média de 6,0\% da MS) sobre a produção de ácido láctico (média de 0,6\%). Esses pesquisadores concluíram, com base em informações da literatura, que a concentração de etanol na fase líquida da silagem (entre 1,4 e 5,2\%) foi alta o suficiente para afetar o desenvolvimento microbiano e contribuir para a preservação das silagens. Hipótese que altera o conceito existente, de que o etanol tem pouca influência no processo fermentativo, advindo do fato de que as silagens normalmente apresentam baixos teores deste álcool. 
As leveduras atingiram sua maior população no $2^{\circ}$ dia após a ensilagem $(5,05$ log ufc/g MV) a partir de quando seu número começou a declinar, sendo que aos 15 dias de ensilagem a população chegou a 4,50 log ufc/g de MV, coincidindo com o ponto onde não foi mais observado acréscimo na concentração de etanol na silagem (Figura 3), indicando que, apesar de estarem presentes, a partir deste ponto as leveduras tiveram seu metabolismo inibido. Dos 45 aos 120 dias após a ensilagem a população de leveduras permaneceu estável em aproximadamente $2 \mathrm{log}$ ufc/g MV. O número de leveduras das amostras de silagem retiradas aos 180 dias de estocagem e da cana-de-açúcar fresca, estiveram abaixo do nível de detecção.

Alli \& Baker (1983) avaliaram o desenvolvimento microbiano em silagem de cana-de-açúcar, relatando que a população inicial de 6,15 log ufc/g MV de leveduras e fungos aumentou no primeiro dia da ensilagem, até aproximadamente $7 \mathrm{log}$ ufc/g, e a partir deste ponto decresceu de forma constante durante todo o período de conservação, atingindo 3,3 log ufc/g aos 21 dias. Não houve produção significativa de etanol após o sétimo dia de ensilagem, quando a população de leveduras e mofos situou-se em aproximadamente 5,1 log ufc/g. Levando-se em conta que a contagem dos microrganismos no trabalho desses pesquisadores abrangeu leveduras e mofos, pode-se considerar que a população de leveduras e a dinâmica de seu desenvolvimento durante a ensilagem, foram semelhantes ao obtido neste experimento.

Ashbell et al. (1987) realizaram um estudo da dinâmica da fermentação de silagem de bagaço de laranja, que se caracteriza por apresentar alto teor de açúcares e intensa fermentação alcoólica, constatando que o número de leveduras atingiu seu pico no segundo dia da ensilagem, quando passou a decrescer até aproximadamente 30 dias, permanecendo então constante, em aproximadamente 1,2 ufc/g MV, até os 60 dias de estocagem. A produção de etanol atingiu concentração estável de $16 \%$ na MS no $5^{\circ}$ da de ensilagem.

Em ambos experimentos citados (Alli \& Baker, 1983; Ashbell et al. (1987), o período de avaliação não foi suficientemente para detectar o comportamento a longo prazo da população de leveduras. Desta forma não é possível estabelecer se o desaparecimento das leveduras após 120 dias de ensilagem, observado no presente 
trabalho, foi um evento casual, devido a problemas de amostragem, ou se pode ser caracterizado como tendência normal.

Para silagens de cana-de-açúcar, os dados são escassos. Bernardes et al. (2002) relataram população de leveduras de 185 ufc/g MS, equivalente a 38,7 ufc/g MV, aos 55 dias de conservação de uma silagem contendo $21 \%$ de MS. O valor está bem abaixo da população detectada no presente trabalho, que foi de 159,5 ufc/g MV (1,91 log ufc/g), no $45^{\circ}$ e $90^{\circ}$ dia de amostragem.

Pode-se observar que a população de bactérias (Figura 4), apresentou padrão de desenvolvimento semelhante ao das leveduras. Partindo de uma população inicial de 4,58 log ufc/g MV apresentou rápido desenvolvimento até o $3^{\circ}$ dia de ensilagem, quando atingiu 7,47 log ufc/g. A partir desse ponto a população bacteriana sofreu redução acentuada e constante até atingir uma contagem de 3,60 log ufc/g aos 45 dias de conservação, quando a população praticamente estabilizou, apresentando contagem de 3,47 log ufc/g na amostragem referente a 180 dias de ensilagem. Uma curva semelhante de desenvolvimento de lactobacilos foi obtida no trabalho, anteriormente mencionado, de Alli et al. (1983) onde a população inicial de lactobacilos, de 6,2 log ufc/g, atingiu aproximadamente 8,3 log ufc/g no primeiro dia da ensilagem, a partir de quando apresentou redução constante até a última observação aos 21 dias.

A variação do $\mathrm{pH}$ evidencia que, o período de acidificação mais acentuada da silagem correspondeu ao período de maior desenvolvimento das bactérias láticas, ou seja, os 3 primeiros dias após a ensilagem (Figura 4). No $3^{\circ}$ dia foi atingido $\mathrm{pH}$ suficientemente baixo $(3,9)$ para inibir o desenvolvimento da maioria das espécies de bactérias normalmente presentes nas silagens, e portanto a população começou a diminuir. Desta forma, a partir do $3^{\circ}$ dia, o $\mathrm{pH}$ sofreu reduções pequenas, porém consideradas significativas $(\mathrm{P}<0,05)$, até o final do período de amostragem (Tabela 1). Em outros trabalhos de pesquisa no entanto, a redução do $\mathrm{pH}$ tem sido mais rápida, como em Bernardes et al. (2002) onde o pH atingiu 3,49 aos 55 dias, e seu valor final mais baixo, como em Lima et al. (2002) onde o pH foi de 3,39, aos 60 dias após a ensilagem da cana-de-açúcar. 
Apesar de ser admitido que as leveduras não são inibidas pelo $\mathrm{pH}$ normalmente encontrado nas silagens (McDonald et al., 1991), a coincidência do momento em que o pH atingiu o valor de 3,9 ( $3^{\circ}$ dia) com o momento onde a população de leveduras começou a declinar (Figura 4), sem que tenha havido esgotamento do substrato, nem concentração de etanol suficientemente alta para inibi-las, sugere que esse nível de pH foi suficiente para causar algum efeito negativo sobre a população desses microrganismos.

A DVIVMS inicial da cana-de-açúcar, que era semelhante à de variedades que têm sido recomendadas para alimentação de bovinos (Rodrigues et al., 2001), sofreu redução de $25 \%$ até o $45^{\circ}$ dia de estocagem, sendo que após esse período a silagem sofreu redução na usa digestibilidade de apenas 3,6\%, até o $180^{\circ}$ dia (Tabela 1). O padrão de redução nos valores da digestibilidade refletiu o aumento da concentração de FDN e FDA na MS da silagem, que apresentaram aumento em suas concentrações de 42,5 e $38,5 \%$, respectivamente, até o $45^{\circ}$ dia e tendência de estabilidade desse ponto até o último dia de amostragem. Na Figura 1 pode-se notar que os primeiros 15 dias de ensilagem corresponderam ao período onde a forragem perdeu mais intensamente seu valor nutritivo (21,3\%), o que coincidiu com o período de produção de etanol e de perdas de CHOs. Nesse período, uma redução aproximada de 13,9 pontos percentuais na concentração de CHOs resultou na perda de 13,4 pontos percentuais na DVIVMS da MS da forragem ensilada (Tabela 1).

Considera-se que o teor de FDN apresenta estreita relação com o consumo das forragens e consequentemente com o desempenho dos animais (Van Soest, 1994). O valor da relação entre os teores de FDN e de sacarose (FDN/sacarose) tem sido utilizada na avaliação da qualidade nutritiva da cana-de-açúcar, sendo que Rodrigues et al. (2001), consideraram o valor 3,0 como sendo indicativo de que a FDN não seria limitante ao consumo de MS, e consequentemente, de açúcares, que fornecem a maior parte da energia digerível para os animais alimentados com esta forragem. Utilizando-se os dados da Tabela 1, pode-se calcular que a relação FDN/CHOs da cana foi aumentada, de aproximadamente 2,0 para 6,5 após 15 dias de ensilagem, indicando portanto, perda acentuada de valor nutritivo durante o processo. 
A Tabela 1 mostra que as frações lignina e cinzas da silagem, bem como a FDN e a FDA, tornaram-se mais concentradas na MS da silagem com o passar do tempo. Isso foi decorrente da perda de nutrientes na forma de gases, e pelo efluente, durante a ensilagem. $\mathrm{O}$ teor de proteína bruta também apresentou maior concentração na MS a partir do $15^{\circ}$ dia de ensilagem $(\mathrm{P}<0,05)$, devido ao mesmo motivo, no entanto pode-se notar que houve diminuição na concentração deste nutriente até o terceiro dia após o fechamento do silo. Tal fato podendo ser creditado à perda de amônia produzida pela ação proteolítica das enzimas das células da forragem, pelas enterobactérias e clostridia, que atuam enquanto $\mathrm{o} \mathrm{pH}$ da silagem não é suficientemente baixo para inibição do processo (McDonald et al., 1991). Quando o $\mathrm{pH}$ da silagem apresentou-se inferior a 4,0 a proteólise foi interrompida e as proteínas começaram a se concentrar na MS, devido principalmente à perda de $\mathrm{CHOs}$ na forma de $\mathrm{CO}_{2}$ e água, pelo metabolismo das leveduras.

Tabela 2. Coeficientes de correlação (r) entre as variáveis qualitativas e os parâmetros referentes às perdas em silagens de cana-de-açúcar

\begin{tabular}{|c|c|c|c|c|c|c|}
\hline & Etanol & CHOs & Perda de gases & Perda total MS & DVIVMS & FDN \\
\hline Etanol (\% MS) & $\begin{array}{ll}-- \\
\end{array}$ & $\overline{---}$ & $\overline{---}$ & $\overline{---}$ & $\overline{---}$ & --- \\
\hline CHOs (\% MS) & $-0,863$ & --- & --- & --- & --- & --- \\
\hline Perda de gases (\% MS) & 0,903 & $-0,962$ & --- & --- & --- & --- \\
\hline Perda total MS (\%) & 0,893 & $-0,958$ & 0,986 & --- & --- & --- \\
\hline DVIVMS (\%) & $-0,879$ & 0,964 & $-0,979$ & $-0,988$ & --- & --- \\
\hline FDN (\% MS) & 0,878 & $-0,966$ & 0,973 & 0,984 & $-0,997$ & --- \\
\hline Efluente (kg/t MV) & 0,565 & $-0,788$ & 0,767 & 0,803 & $-0,822$ & 0,802 \\
\hline
\end{tabular}

A concentração de etanol esteve inversamente relacionada com o teor de CHOs residuais $(\mathrm{r}=-0,863)$ e a digestibilidade da silagem $(\mathrm{r}=-0,879)$, indicando que a produção de etanol consumiu açúcares da silagem, causando diminuição do seu valor nutritivo (Tabela 2). Para a silagem de cana-de-açúcar produzida sem aditivos, a perda de MS na forma de gases apresentou relação direta com a concentração de etanol $(r=$ 0,903), com a perda total de MS $(r=0,986)$ e com a concentração de fibra (FDN) ( $r=$ 0,973), e relação inversa com a concentração de CHOs $(r=-0,962)$ e com a DVIVMS 
$(r=-0,979)$. Dessa forma, a produção de gases revelourse como um bom indicativo da qualidade que se pode esperar das silagens, ou seja, pode-se sugerir que silagens de cana-de-açúcar que produzam mais gases estarão mais susceptíveis a apresentar maior concentração de etanol, maior perda total de MS, e consequentemente menor valor nutritivo.

A produção de efluentes, nas condições deste experimento, apresentou relação direta com os outros indicativos de perdas e relação inversa com a concentração de CHOs e com a digestibilidade da silagem (Tabela 2). No entanto, esse fato deve ser considerado com cautela, tendo em vista que após o $45^{\circ}$ dia de ensilagem não houve acréscimos significativos na perda total de MS, apesar da produção constante de efluentes até o fim do período de amostragem, indicando que a perda de efluentes pode não ter sido uma fonte significativa de perdas de MS e de qualidade da silagem, como já foi discutido.

\subsection{Conclusões}

A ensilagem da cana-de-açúcar foi caracterizada pela intensa fermentação alcoólica nos primeiros 15 dias após o fechamento dos minisilos, o que resultou em perdas excessivas de MS e CHOs, principalmente na forma de gases, causando acúmulo dos componentes da parede celular e perda de $25 \%$ na DVIVMS da forragem. Os resultados indicam que métodos de controle da fermentação alcoólica devem ser desenvolvidos, para a viabilização do uso de silagens de cana, e que isto implica na necessidade de inibição do desenvolvimento das leveduras desde a fase inicial da ensilagem. 


\section{ADITIVOS QUÍMICOS E INOCULANTES MICROBIANOS EM SILAGENS DE CANA-DE-AÇÚCAR: EFEITOS SOBRE A COMPOSIÇÃO, AS PERDAS DE MATÉRIA SECA E A ESTABILIDADE AERÓBICA}

\section{Resumo}

O objetivo deste estudo foi avaliar a eficácia de aditivos químicos e inoculantes microbianos na inibição da produção de etanol, na diminuição das perdas de matéria seca (MS) e no aumento da estabilidade aeróbica em silagens de cana-de-açúcar colhida após doze meses de crescimento vegetativo. A ensilagem foi realizada em baldes de plástico de 20 litros (minisilos) adaptados com válvulas para eliminação de gases e dispositivo para colheita de efluentes. Os aditivos aplicados foram (com base na massa verde): uréia $(0,5 ; 1,0 ; 1,5 \%) ; \mathrm{NaOH}(1 ; 2 ; 3 \%)$; propionato de cálcio-PROP $(0,05 ; 0,1 ;$ $0,2 \%)$; benzoato de sódio-BENZ $(0,05 ; 0,1 ; 0,2 \%)$; sorbato de potássio-SORB $(0,015$; 0,03; 0,045\%); L. plantarum-BAL (1 x $\left.10^{6} \mathrm{ufc/g}\right) ;$ L. buchneri-BUCH (3,64 x $\left.10^{5} \mathrm{ufc/g}\right)$; uréia $(0,5$ e $1,0 \%)$ combinada com $L$. plantarum-Lact/Ur 0,5\% e Lact/Ur 1,0\%. As amostragens foram realizadas no dia da ensilagem e após 90 e 180 dias de fermentação. As perdas totais de MS, por gases e efluentes foram estimadas por gravimetria. A perda da estabilidade aeróbica foi estimada pelo controle da temperatura das silagens expostas ao ar. Nenhum dos aditivos foi capaz de reduzir $(\mathrm{P}>0,05)$ a concentração de etanol e os tratamentos PROP-0,1\% e BAL causaram aumento $(\mathrm{P}<0,05)$ no teor do álcool em relação à silagem controle $(4,8$ e $12,5 \%$ vs $3,8 \%$ da $\mathrm{MS}$, respectivamente). Os tratamentos com uréia, NaOH, SORB-0,03\%, BUCH, Lact/Ur 0,5\% e Lact/Ur 1,0\% causaram diminuição da perda total de MS das silagens $(\mathrm{P}<0,05)$ em relação à silagem 
sem aditivos, que apresentou perda total de 18,2\% da MS. As silagens tratadas com uréia, $\mathrm{NaOH}, \mathrm{BENZ}$, e SORB-0,045\% apresentaram maior digestibilidade do que a silagem controle $(\mathrm{P}<0,05)$, que apresentou DVIVMS de 45,4\%. O tratamento das silagens com BUCH, Lact/Ur 1,0\%, uréia-1,5\%, $\mathrm{NaOH}$ (1 e 2\%) e BENZ-0,2\% resultaram em silagens com maior estabilidade aeróbica em relação à silagem sem aditivos, que foi estável por 65 horas.

\section{CHEMICAL AND MICROBIAL ADDITIVES IN SUGAR CANE SILAGES: EFFECTS ON SILAGE COMPOSITION, DRY MATTER LOSSES AND AEROBIC STABILITY}

\section{Summary}

The goal of this trial was to evaluate the effects of the following treatments (wet basis): urea $(0.5 ; 1.0 ; 1.5 \%), \mathrm{NaOH}(1 ; 2 ; 3 \%)$, calcium propionate-PROP $(0.05 ; 0.1$; $0.2 \%)$, sodium benzoate-BENZ $(0.05 ; 0.1 ; 0.2 \%)$, potassium sorbate-SORB (0.015; 0.03; 0.045\%), L. plantarum-LAB (1 x $\left.10^{6} \mathrm{ufc} / \mathrm{g}\right)$, L. buchneri-BUCH $\left(3.64 \times 10^{5} \mathrm{ufc} / \mathrm{g}\right)$, urea $(0.5$ e $1.0 \%)$ plus L. plantarum-Lact/Ur $0.5 \%$ and Lact/Ur $1.0 \%$ on silage quality, dry matter (DM) losses and aerobic stability. Sugar cane was ensiled in $20 \mathrm{~L}$ plastic buckets provided with valves for gases release and a device for effluent collection. Total DM, gases and effluent losses were evaluated through gravimetry. Aerobic stability was estimated by monitoring temperature evolution in silage samples exposed to air. Comparison of additive treated silages with control 90 and 180 days after sealing indicated: none of the additives were effective to reduce ethanol concentration in the silages and PROP- $0.1 \%$ and $\mathrm{LAB}$ even increased $(\mathrm{P}<0.05)$ alcohol levels $(4.8$ and $12.5 \%$ vs $3.8 \%$ in control DM); urea, $\mathrm{NaOH}$, SORB-0.03\%, BUCH, Lact/Ur 0.5\% and Lact/Ur $1.0 \%$ treated silages showed lower total DM losses $(\mathrm{P}<0.05)$; higher IVDDM was achieved by adding urea, $\mathrm{NaOH}, \mathrm{BENZ}$ and SORB-0,045\% $(\mathrm{P}<0.05)$; aerobic stability was improved with BUCH, Lact/Ur 1.0\%, urea-1.5\%, $\mathrm{NaOH}(1$ and 2\%) and BENZ$0.2 \%$ treatments $(\mathrm{P}<0.05)$. 


\subsection{Introdução}

O uso da cana-de-açúcar na alimentação de bovinos é amplamente difundido no Brasil, sendo esta tradicionalmente fornecida fresca aos animais. Exigências de manejo dos canaviais, incêndios e a ocorrência de geadas, têm levado os pecuaristas a buscarem na ensilagem uma forma alternativa de uso desta forrageira. Silagens de cana-de-açúcar apresentam no entanto, intensa atividade de leveduras que convertem açúcares a etanol, $\mathrm{CO}_{2}$ e água, causando reduções de até $44 \%$ no teor de carboidratos solúveis, aumento nos componentes da parede celular e das perdas de MS nas forragens assim conservadas (Alli et al., 1983). Teores de etanol na ordem de 7,8\% a 17,5\% da MS têm sido relatados para cana-de-açúcar ensilada sem o uso de aditivos, resultando em perdas de até $29 \%$ da MS durante o processo (Kung Jr. \& Stanley, 1982; Andrade et al., 2001; Silva, 2003).

As leveduras não são inibidas pelo $\mathrm{pH}$ encontrado nas silagens. Para a maioria das espécies existentes nas silagens o pH ótimo encontra-se entre 3,5 e 6,5, sendo que algumas espécies são capazes de sobreviver em pH igual ou inferior 2 (McDonald et al., 1991). Altas contagens de leveduras causam também a deterioração aeróbica e perda no valor nutritivo de silagens expostas ao ar, durante a estocagem ou após a abertura dos silos, promovendo a elevação do $\mathrm{pH}$ e aumentando o risco de desenvolvimento de microrganismos patogênicos como a Listeria monocytogenes (Rotz \& Muck, 1994). Por isso, aditivos químicos e microbianos têm sido utilizados com o intuito de evitar o desenvolvimento das leveduras, diminuindo as perda de MS das silagens, embora muitos não tenham sido avaliados na ensilagem da cana-de-açúcar, com vistas ao controle da produção de etanol.

O efeito da uréia sobre a fermentação de silagens de cana-de-açúcar foi avaliado em alguns experimentos, pois em contato com a forragem ensilada esse aditivo se transforma em amônia $\left(\mathrm{NH}_{3}\right)$ que tem efeito inibidor sobre a população de leveduras e mofos, reduzindo a produção de etanol, as perdas de MS e de carboidratos solúveis (CHOs) da forragem ensilada (Alli et al., 1983). Níveis entre 0,5 e 1,5\% de uréia propiciaram bom padrão de fermentação e melhor composição bromatológica, com teores mais elevados de MS associados a menores concentrações de FDA e FDN nas 
silagens tratadas, em comparação a silagens de cana exclusiva (Lima et al., 2002; Molina et al., 2002).

Substâncias alcalinizantes também são capazes de modificar o processo de fermentação das silagens. Silagens de cana-de-açúcar tratadas com 3 a $4 \%$ de $\mathrm{NaOH}$ apresentaram melhor composição bromatológica, redução acentuada na produção de etanol (de aproximadamente 5,2\% para 0,88\% da MS), maior teor de ácido lático, maior digestibilidade da MS e resultaram em aumentos no consumo e no ganho de peso dos animais com elas alimentados, em relação a silagens sem aditivos (Castrillón et al., 1978; Alcántara et al., 1989).

O crescimento de microrganismos pode ser evitado por ácidos orgânicos fracos, como os ácidos fórmico, acético e propiônico, que têm a capacidade de se difundir pela membrana plasmática na sua forma não dissociada, diminuindo o $\mathrm{pH}$ do citoplasma e afetando negativamente a glicólise e o sistema de transporte ativo das células, em um processo dependente do $\mathrm{pH}$ e da concentração de açúcares do meio (McDonald et al., 1991; Lambert \& Stratford, 1999). Apesar de não haver relatos da avaliação destes ácidos na ensilagem da cana-de-açúcar, seu uso mostrou-se eficiente no controle do desenvolvimento de fungos e na melhoria da estabilidade aeróbica de silagens de azevém e milho (Ohyama et al., 1975; Britt et al., 1975).

Alguns produtos químicos utilizados como conservantes na indústria alimentícia têm sido testados como aditivos para silagem. Os ácidos sórbico e benzóico mostraram poder inibir o crescimento de leveduras em testes de laboratório (Woolford, 1975) e o benzoato de sódio combinado à hexamina melhorou a conservação de silagens de capim emurchecido, com redução no número de leveduras e diminuição na perda de CHOs das silagens quando estas foram expostas ao ar (Lättemäe e Lingvall, 1996).

A elevação artificial, nas forragens ensiladas, do número de bactérias homofermentativas produtoras de ácido lático, pode reduzir o $\mathrm{pH}$ final, aumentar $\mathrm{o}$ conteúdo de ácido lático, diminuir a produção de efluentes e a perda de matéria seca durante a conservação das silagens (McDonald et al., 1991), no entanto, os efeitos sobre a população de leveduras e a estabilidade aeróbica são variáveis (Higginbotham et al., 1998, Driehuis \& Wikselaar, 2000). Por outro lado, inoculantes contendo a bactéria 
heterofermentativa $L$. buchneri, que produz ácido acético além do ácido lático, têm mostrado eficiência consistente no controle do desenvolvimento de leveduras e no aumento da estabilidade aeróbica das silagens (Ranjit \& Kung, Jr., 2000).

O objetivo deste experimento foi avaliar novos aditivos, como o benzoato de sódio, o sorbato de potássio e o propionato de cálcio e inoculantes microbianos contendo L. plantarum e L. buchneri, comparando-os a outros já utilizados (uréia e hidróxido de sódio) na ensilagem da cana-de-açúcar. Foram avaliados os efeitos sobre o controle da produção de etanol, as perdas de MS, a qualidade e a estabilidade aeróbica das silagens, sendo que os aditivos químicos foram testados em diversas doses.

\subsection{Material e Métodos}

As silagens foram produzidas com a cana-de-açúcar RB785841, colhida madura (primeiro corte; aproximadamente 13 meses de crescimento) com uma colhedora da marca Mentamit ${ }^{\circledR}$ acoplada ao trator e regulada para corte com tamanho de partículas médio entre 5 a $10 \mathrm{~mm}$. Após a ensilagem, realizada no dia 18 de agosto de 2001, os minisilos foram mantidos em local coberto, sob temperatura ambiente, no Setor de Ruminantes do Departamento de Zootecnia da ESALQ/USP de Piracicaba. A determinação do grau brix da cana-de-açúcar foi realizada por meio de refratômetro de campo (marca TOKYO ${ }^{\circledR}$, modelo 032) e indicou valor médio de $22,5^{\circ}$.

\subsubsection{Silos experimentais e produção das silagens}

Como silos experimentais (unidades experimentais) foram utilizados baldes de plástico de 20 litros (minisilos), com tampas próprias à vedação e adaptadas com válvulas do tipo Bunsen, para que fosse possível a avaliação das perdas gasosas durante a ensilagem. No fundo de cada balde foram colocados dois quilos de areia seca, separados da silagem por tela fina de plástico e duas camadas de tecido fino de algodão, com vista à avaliação quantitativa de efluentes. 
A ensilagem foi realizada, compactando-se com os pés camadas de 5 a $10 \mathrm{~cm}$ de espessura da cana-de-açúcar picada, buscando-se atingir a maior quantidade possível de forragem em cada balde, para uniformização da densidade das silagens entre os silos. Aproximadamente $9 \mathrm{~kg}$ de forragem foram ensilados em cada balde, resultando em densidade aproximada de $500 \mathrm{~kg} / \mathrm{m}^{3}$ na silagem, levando-se em conta o volume do balde que foi preenchido com areia.

Após o enchimento os minisilos foram fechados com as tampas apropriadas e pesados. Após a pesagem as tampas foram vedadas com fita plástica auto-adesiva, para impedimento da entrada de ar.

\subsubsection{Tratamentos e aplicação dos aditivos}

Os tratamentos consistiram em níveis crescentes de cinco aditivos químicos, dois inoculantes microbianos e duas combinações entre estes. Os aditivos químicos testados foram: uréia na forma de fertilizante granulado contendo $45 \%$ de $\mathrm{N}$; hidróxido de sódio $(\mathrm{NaOH})$ em solução aquosa $50 \%$; propionato de cálcio em pó solúvel; benzoato de sódio granulado solúvel e sorbato de potássio em pó solúvel. Os inoculantes microbianos utilizados foram: Ecosyl ${ }^{\circledR} \quad($ ECOSYL Products Limited - número de registro na Inglaterra: 3155665), contendo bactérias homoláticas L. plantarum e um inoculante não comercial contendo bactérias heteroláticas L. buchneri (cepa NCIMB 40788) fornecido pela Biotal $^{\circledR}$ Ltd (Cardiff, UK). Foram ainda testadas aplicações conjuntas de uréia $(0,5$ e 1,0\%) com L. plantarum (Lact/Ur 0,5\% e Lact/Ur 1,0\%).

Os aditivos químicos foram aplicados à cana-de-açúcar picada antes do enchimento dos baldes, na forma de soluções aquosas, por meio de pulverizadores manuais de 5 litros (da marca Brudden ${ }^{\circledR}$, Brudden Equipamentos Ltda) e os inoculantes microbianos com o uso de pulverizadores manuais pequenos (do tipo utilizado em pulverizações caseiras) com capacidade para $500 \mathrm{~mL}$, buscando-se distribuição uniforme dos produtos na massa a ser ensilada. Os aditivos químicos foram utilizados nas seguintes concentrações (em relação ao peso da forragem fresca): uréia $=>0,5 ; 1,0$ e 1,5\%; $\mathrm{NaOH}$ $=>1 ; 2$ e $3 \%$; propionato de cálcio $=>0,05 ; 0,1$ e $0,2 \%$; benzoato de sódio $=>0,05 ; 0,1$ e 
$0,2 \%$; sorbato de potássio $=>0,015 ; 0,03$ e $0,045 \%$. Os inoculantes microbianos foram aplicados, de acordo com a recomendação dos fabricantes, visando-se a adição de $1 \times 10^{6}$ ufc/g de forragem fresca, para o inoculante contendo L. plantarum, e 3,64 x $10^{5} \mathrm{ufc} / \mathrm{g}$ para o inoculante contendo L. buchneri.

A uréia foi aplicada utilizando-se 35 litros solução/t de forragem e os aditivos benzoato, propionato e sorbato, utilizando-se 10 e 12 litros de solução/t de forragem, para as menores e maiores concentrações respectivamente, para facilitar a diluição dos produtos. A solução de $\mathrm{NaOH} 50 \%$ foi utilizada sem diluição, nas quantidades de 20, 40 e 60 litros/t para obtenção das três concentrações indicadas. Os inoculantes BAL e BUCH foram aplicados em baixo volume, ou seja, 1,89 litros de solução/t de forragem.

\subsubsection{Avaliação das perdas e amostragem das silagens}

Os efeitos dos tratamentos foram avaliados aos 90 e 180 dias após a ensilagem, quando 3 minisilos de cada tratamento foram pesados e abertos para amostragem. Os baldes foram pesados também antes da ensilagem, com a tampa e contendo o aparato de recepção de efluentes, para que fosse possível o cálculo do peso líquido da forragem contida em cada minisilo e, posteriormente, dos efluentes.

Em cada dia de amostragem procedeu-se à retirada das fitas adesivas e pesagem dos minisilos antes da abertura, após o que realizava-se a tomada de amostras de silagem, retirada da forragem dos baldes e pesagem dos mesmos contendo apenas o aparato de colheita de efluentes.

Cada amostra de silagem foi composta por duas a três porções retiradas da parte central da massa de forragem contida em cada silo. As amostras destinadas à determinação dos teores de etanol foram colocadas em sacos de plástico e estocadas em congelador $\left(-5^{\circ} \mathrm{C}\right)$ e as amostras utilizadas para as demais análises bromatológicas foram colocadas em sacos de papel e secas em estufa a $60^{\circ} \mathrm{C}$ por $48 \mathrm{~h}$.

A perda de matéria seca na forma de gases foi calculada pela diferença entre o peso bruto inicial e final dos silos experimentais e a quantidade de efluentes pela diferença entre o peso inicial e final dos baldes contendo apenas a areia, a tela plástica e 
o tecido de algodão. A perda de matéria seca total das silagens, foi calculada pela diferença entre o peso da matéria seca da forragem inicialmente colocada em cada minisilo e o peso da matéria seca da silagem no dia da abertura.

\subsubsection{Análises químico-bromatológicas}

As amostras secas das silagens foram moídas contra peneira de malha de $1 \mathrm{~mm}$ e posteriormente analisadas pelo método da espectroscopia de reflectância de infravermelho proximal (NIRS) (Berzaghi et al., 1997; Cozzolino et al., 2001) utilizando-se um espectrofotômetro modelo NIRS $5000^{\circledR}$ (NIRSystems, Silver Spring, MD, USA). A análise utilizou comprimentos de onda entre 700 e $2100 \mathrm{~nm}$ e os espectros das amostras "escaneadas" foram armazenados em curvas log (1/R) em intervalos de 2nm. O método de seleção existente no "software" do equipamento identificou as amostras distantes mais de $3 \mathrm{H}$ (distância padronizada de Mahalanobis) da média, "outliers", que foram excluídas. Adotando-se uma distância mínima de 0,6 H entre amostras (Shenk \& Westerhaus, 1991), foram selecionadas as que deveriam ser analisadas pelos métodos da bromatologia convencional. De posse dos resultados destas análises, o programa do equipamento NIRS foi capaz de inferir a composição química e bromatológica das demais amostras.

As análises das amostras selecionadas pelo método NIRS foram realizadas como segue:

- matéria seca em estufa a $105^{\circ} \mathrm{C}$ por 8 horas.

- a matéria mineral (cinzas) foi obtida pela incineração das amostras em mufla a $600{ }^{\circ} \mathrm{C}$ por 3 horas.

- os teores de fibra em detergente neutro (FDN) e a digestibilidade verdadeira "in vitro" matéria seca (DVIVMS) foram determinados através do método ANKON $^{\circledR}$ Fiber Analyser (ANKON Technology Corporation, Fairport, NY).

- os teores de fibra em detergente ácido (FDA) e de lignina (LIG) foram avaliados segundo os métodos propostos por Van Soest et al. (1985) e a proteína bruta (PB) segundo AOAC (1990). 
- o teor de PB para o tratamento com uréia foi determinado pelo método macro Kjeldahl (AOAC, 1990), em amostras úmidas de silagem que haviam sido mantidas congeladas $\left(-5^{\circ} \mathrm{C}\right)$.

Os teores de etanol foram determinados em extratos aquosos das amostras de silagem, obtidos segundo método descrito por Kung, Jr. (1996). Para isto, 25 g de amostra úmida foram processados com $225 \mathrm{~mL}$ de água destilada, em liquidificador, durante um minuto. Em seguida, o material foi filtrado em papel de filtro Whatman ${ }^{\circledR} 54$, acidificado com $\mathrm{H}_{2} \mathrm{SO}_{4}$ a $50 \%$ e centrifugado, sendo o extrato líquido armazenado em congelador $\left(-5^{\circ} \mathrm{C}\right)$ até o momento das análises. $\mathrm{O} \mathrm{pH}$ foi determinado nos extratos, antes da filtragem, através de um potenciômetro digital da marca Digimed ${ }^{\circledR}$, modelo DM 20. As análises do teor de etanol foram realizadas nos laboratórios do Setor de Açúcar e Álcool do Departamento de Agroindústria Alimentos e Nutrição da ESALQ/USP de Piracicaba, por meio de cromatógrafo a gases com detector de ionização de chama, marca Gregório e Cioli ${ }^{\circledR}$, modelo CG-37D.

\subsubsection{Avaliação da estabilidade aeróbica}

A estabilidade aeróbica das silagens (expressa em horas) foi avaliada através do controle da temperatura das silagens expostas ao ar, segundo método adaptado de Kung, Jr. (2000). Amostras únicas de aproximadamente 3,5 kg das silagens de cada tratamento, foram colocadas sem compactação em baldes de plástico sem tampa, mantidos em local fechado para evitar-se grandes variações na temperatura ambiente. As temperaturas foram tomadas 3 vezes ao dia $(08: 00$, 15:00 e 20:00 h) por meio de termômetros posicionados no centro geométrico da massa de forragem de cada balde. Considerou-se o início da deterioração quando a temperatura das silagens atingiu $2^{\circ} \mathrm{C}$ acima da temperatura ambiente, que apresentou média de $26,4{ }^{\circ} \mathrm{C}$ e variação entre 25 e $28{ }^{\circ} \mathrm{C}$, tendo sido medida com um termômetro localizado próximo aos baldes. Também foi considerado na avaliação da estabilidade aeróbica, o acúmulo de cinco dias, da diferença média diária entre a temperatura das silagens expostas ao ar e a temperatura ambiente (ADITE-5; expressa em ${ }^{\circ} \mathrm{C}$ ). 


\subsubsection{Análise estatística}

O delineamento experimental utilizado foi o inteiramente casualizado, com três repetições, em esquema de parcelas subdivididas (split-plot), sendo os fatores das parcelas os tratamentos impostos e o fator atribuído à subparcela (90 e 180 dias). O teor de MS inicial da cana-de-açúcar, de cada tratamento, foi testado como covariável, e diante da ausência de efeito foi removido do modelo original.

O modelo proposto foi analisado pelo PROC GLM do programa SAS (SAS, 1988) e a comparação das médias foram realizadas utilizando-se o Método dos Quadrados Mínimos (LSMEANS). Foram declaradas significativas as diferenças entre as médias a partir de $\mathrm{P}<0,05)$. Aplicou-se o teste $\mathrm{F}$ para contraste, a partir do desdobramento dos graus de liberdade. O objetivo foi comparar os parâmetros das silagens nos diversos períodos de abertura dos silos.

\subsection{Resultados e Discussão}

\subsubsection{Efeito dos tratamentos sobre a qualidade e as perdas de MS das silagens}

Os dados contidos na Tabela 3 mostram que, a cana-de-açúcar utilizada para ensilagem no tratamento controle (sem aditivos) apresentou níveis semelhantes de MS e níveis superiores de FDN, FDA e LIG em relação aos valores médios relatados por Andrade et al. (2002), que avaliaram 60 variedades de cana-de-açúcar para uso na alimentação de ruminantes, colhidas aos 12 meses de idade, encontrando teores de MS variando entre 24 e $37 \%$, de FDN entre 36 e 56\%, de FDA entre 21 e $36 \%$ e de lignina entre 3 e 7\% da MS, aproximadamente. O valor da DVIVMS foi intermediário aos apresentados por dezoito variedades de cana-de-açúcar avaliadas por Rodrigues et al. (2001) (58 a 69\%). O teor de PB esteve próximo aos níveis apresentados na literatura (Lima \& Mattos, 1993; Kung, Jr. \& Stanley, 1982). A concentração de PB da cana-deaçúcar após a adição de uréia atingiu o valores próximos aos esperados, ou seja, aproximadamente 8, 10 e 20\% de PB na MS da forragem para as inclusões de 0,5 1,0 e 
1,5\% de uréia, respectivamente. A maior DVIVMS e os menores teores de FDN das canas tratadas com $\mathrm{NaOH}$ refletiram o rápido efeito do aditivo sobre a forragem. Os valores dos demais nutrientes, das canas dos outros tratamentos, estiveram próximos aos da cana-de-açúcar do tratamento controle, com exceção da maior concentração de cinzas nos tratamentos onde se utilizou uréia e $\mathrm{NaOH}$. Os teores de MS inicial dos tratamentos com benzoato e sorbato foram numericamente superiores ao controle, provavelmente

Tabela 3. Composição bromatológica da cana-de-açúcar utilizada nos tratamentos, antes da ensilagem

\begin{tabular}{|c|c|c|c|c|c|c|c|}
\hline \multirow[t]{2}{*}{ Tratamento $^{1}$} & M.S. & DVIVMS & $\overline{P B}$ & FDN & FDA & LIG & Cinzas \\
\hline & \multicolumn{2}{|c|}{$\%$} & \multicolumn{5}{|c|}{$\% \mathrm{MS}$} \\
\hline Controle & 29,8 & 53,2 & 4,05 & 57,3 & 38,4 & 6,36 & 4,57 \\
\hline Uréia $0,5 \%$ & 28,9 & 50,5 & 7,79 & 57,7 & 39,7 & 7,24 & 6,04 \\
\hline Uréia $1,0 \%$ & 27,9 & 49,9 & 9,97 & 57,9 & 40,4 & 7,54 & 6,42 \\
\hline Uréia $1,5 \%$ & 26,7 & 51,5 & 19,5 & 56,9 & 38,8 & 6,83 & 4,70 \\
\hline $\mathrm{NaOH} 1 \%$ & 29,4 & 63,8 & 5,36 & 49,7 & 36,1 & 4,87 & 8,76 \\
\hline $\mathrm{NaOH} 2 \%$ & 30,3 & 70,0 & 5,28 & 45,7 & 34,9 & 4,22 & 9,50 \\
\hline $\mathrm{NaOH} 3 \%$ & 32,5 & 71,0 & 5,36 & 46,1 & 35,5 & 4,13 & 9,38 \\
\hline Benzoato $0,05 \%$ & 30,1 & 55,9 & 3,67 & 53,4 & 36,2 & 6,03 & 3,93 \\
\hline Benzoato $0,1 \%$ & 30,1 & 56,6 & 3,91 & 51,9 & 35,5 & 5,85 & 4,15 \\
\hline Benzoato $0,2 \%$ & 30,5 & 55,8 & 3,68 & 53,3 & 36,8 & 6,14 & 4,08 \\
\hline Propionato $0,05 \%$ & 27,3 & 55,4 & 4,27 & 53,0 & 36,1 & 6,12 & 4,46 \\
\hline Propionato $0,1 \%$ & 29,1 & 57,2 & 3,81 & 51,9 & 35,3 & 5,67 & 4,27 \\
\hline Propionato $0,2 \%$ & 29,7 & 56,1 & 3,88 & 53,5 & 36,1 & 5,70 & 4,34 \\
\hline Sorbato $0,015 \%$ & 31,3 & 54,1 & 3,59 & 55,8 & 37,8 & 6,09 & 5,20 \\
\hline Sorbato $0,03 \%$ & 31,3 & 53,0 & 4,13 & 57,7 & 39,0 & 6,29 & 5,36 \\
\hline Sorborbato $0,045 \%$ & 30,0 & 56,4 & 5,08 & 52,6 & 35,6 & 5,52 & 3,18 \\
\hline L. buchneri $3,64 \times 10^{5} \mathrm{ufc} / \mathrm{g} \mathrm{MV}$ & 27,4 & 55,0 & 3,82 & 51,4 & 35,4 & 6,15 & 5,84 \\
\hline L. plantarum $1 \times 10^{6}$ ufc/g MV & 28,1 & 53,1 & 3,93 & 56,7 & 38,3 & 6,55 & 4,51 \\
\hline Lact/Ur $0,5 \%$ & 26,3 & 50,1 & 7,13 & 57,9 & 40,1 & 7,37 & 6,41 \\
\hline Lact/Ur $1,0 \%$ & 28,5 & 48,1 & 10,3 & 61,3 & 42,0 & 7,67 & 6,22 \\
\hline Média & 29,3 & 55,8 & 5,93 & 54,1 & 37,4 & 6,12 & 5,57 \\
\hline Máximo & 32,5 & 71,0 & 19,5 & 61,3 & 42,0 & 7,67 & 9,50 \\
\hline Mínimo & 26,3 & 48,1 & 3,59 & 45,7 & 34,9 & 4,13 & 3,18 \\
\hline
\end{tabular}


devido à perda de umidade sofrida pela forragem com o decorrer do tempo, já que a cana foi colhida e picada no início da manhã e o enchimento dos minisilos, com esses dois aditivos, foi realizado no final da tarde.

$\mathrm{Na}$ Tabela 4 pode-se ver que nenhum dos aditivos utilizados foi capaz de causar redução na concentração de etanol das silagens $(\mathrm{P}>0,05)$, em relação à silagem controle, no entanto, o propionato adicionado no nível de $0,1 \%$ da MV e o inoculante contendo L. plantarum levaram a níveis mais altos deste álcool nas silagens $(\mathrm{P}<0,05)$. $\mathrm{O}$ teor de etanol observado para a silagem controle pode ser considerado baixo, uma vez que os dados da literatura indicam valores entre 5,5 a 15,5\% deste álcool na MS de silagens de cana-de-açúcar colhidas aos 12 meses de crescimento e ensiladas sem aditivos (Preston et al., 1976; Kung, Jr. \&Stanley, 1982).

Os carência de dados na literatura tornam difícil a avaliação dos valores de perdas de MS por gases e da perda total de MS das silagens deste experimento (Tabela 4). McDonald et al. (1991) afirmaram que, em silagens bem preservadas, as perdas de MS por oxidação, durante o enchimento do silo, e por fermentação, devem situar-se entre 2 e $4 \%$ e citam referências onde as perdas totais de MS variaram de 0,8 a $71 \%$ (média de 19,4\%). Rotz \& Muck, (1994), em um modelo de simulação de perdas durante a ensilagem, previram perdas totais de $17,7 \%$ da MS, para silagens onde houve produção de efluentes. A perda de MS na forma de gases da silagem controle neste experimento atingiu valor duas vezes maior do que aquele relatado por Alli et al. (1982) que, para uma silagem com $8,86 \%$ de etanol, obtiveram 5,2\% de perdas gasosas num período de 10 dias. No entanto, considerando-se que estudo anterior mostrou que as perdas gasosas podem aumentar (linearmente) até aproximadamente 15 dias da ensilagem (capítulo 3 desta tese) é provável que no experimento conduzido por Alli et al. (1982) não tenha sido possível constatar uma maior intensidade das perdas gasosas, em decorrência do período curto de avaliação da silagem. A perda total de MS foi menor do que a obtida por Kung, Jr. \& Stanley, (1982) que obtiveram 29\% de perdas da MS, para cana ensilada aos 15 messes de crescimento e conservada durante 60 dias. Porém, o teor de etanol da silagem obtido por estes autores foi aproximadamente quatro vezes maior, ou seja, $13,7 \%$ da MS. 
Em alguns tratamentos, os valores obtidos de perda total de MS foram inferiores àqueles estimados para perda por gases. Isto ocorreu quando as diferenças foram pequenas e deve-se, provavelmente, a erros acumulativos de pesagem dos baldes e das amostras.

Não existem dados sobre a perda de efluentes em silagens de cana. A produção de $15,1 \mathrm{~kg} / \mathrm{t}$ de MV da silagem controle (Tabela 4) pode ser considerada normal para o teor de MS da forragem. Apesar do teor de MS inicial ter sido suficiente para evitar uma produção significativa de efluentes, com a intensa atividade microbiana (caracterizada pela produção de etanol e perdas de MS) houve consumo de nutrientes e produção de $\mathrm{H}_{2} \mathrm{O}$ metabólica, reduzindo o teor de MS da silagem até o nível de $25 \%$, onde a produção de 20 litros de efluentes/tonelada seria esperada (McDonald et al., 1991).

A redução no teor de MS da silagem controle (Tabelas 3 e 5) foi de aproximadamente 15\%, estando portanto abaixo dos níveis encontrados na literatura, que variam entre 19 e $31 \%$, e o $\mathrm{pH}$ (Tabela 4) situou-se bastante próximo ao valor mais alto encontrado, que foi de 3,6 (Alli et al., 1982; Kung Jr. \& Stanley, 1982; Coan et al., 2002).

Segundo Rotz \& Muck (1994), silagens bem manejadas apresentam aumento nas concentrações de FDN e FDA, variando entre 1 e $6 \%$ em relação aos teores originalmente presentes na forragem, como consequiência da perda de carboidratos solúveis por respiração, o que provoca o aumento da participação percentual daqueles nutrientes na MS da forragem. Segundo esses autores, o teor de proteína bruta também pode sofrer aumentos de 1 a $2 \%$ na MS devido ao mesmo processo. Levando-se em conta que, quando ocorre fermentação alcoólica a perda de carboidratos solúveis é maior, pode-se assumir que deve ocorrer maior concentração dos componentes da parede celular na MS durante a ensilagem da cana-de-açúcar. Os valores de FDN encontrados na silagem controle (Tabela 5) foram altos em relação aos encontrados na literatura, devendo-se considerar que o nível de FDN encontrado na cana fresca também foi elevado, no entanto o acréscimo no teor deste nutriente foi de $13 \%$ durante ao período de estocagem podendo ser considerado baixo, sendo que Coan et al. (2002) constataram aumento de $30 \%$ na FDN durante a ensilagem da cana-de-açúcar. A porção 
FDA apresentou teor normal na silagem, com acréscimo de $15 \%$ durante o período de estocagem, que também pode ser considerado inferior à média, uma vez que avaliando dados da literatura constatourse aumentos na ordem de 26 a $44 \%$ para este componente (Alli et al., 1982; Coan et al., 2002). A diminuição no valor original da DVIVMS, durante a ensilagem, no tratamento controle foi de aproximadamente $15 \%$. Os índices relativos às silagens deste experimento foram calculados com base nos dados das Tabelas 1 e 3.

Avaliando o efeito dos aditivos (Tabelas 2 e 3) constata-se que a silagem tratada com L. plantarum apresentou a maior concentração de etanol $(\mathrm{P}<0,05)$ e perda total de MS dentro do nível mais elevado, sendo a perda por gases responsável por aproximadamente $69 \%$ das perdas totais da MS. A produção de efluentes também situou-se entre os maiores valores observados neste trabalho. O maior teor de etanol desta silagem foi acompanhado pelo menor $(\mathrm{P}<0,05)$ valor de DVIVMS, correspondente à perda de 22,5\% do valor da digestibilidade original da cana fresca. Os teores de FDN, FDA e lignina foram mais elevados e o teor de MS foi o mais baixo entre todos os tratamentos $(\mathrm{P}<0,05)$, correspondendo à redução de $15,7 \%$ do valor original da forragem. A alta concentração de etanol indica que a adição de L. plantarum não controlou o desenvolvimento das leveduras, confirmando a informação da literatura de que apenas o abaixamento do $\mathrm{pH}$ não é suficiente para impedir o desenvolvimento destes microrganismos e que o ácido lático tem baixo poder fungicida (McDonald et al. 1991). O resultado está de acordo com o obtido em outros trabalhos que mostraram que, a aplicação de inoculantes contendo bactérias homofermentativas produtoras de ácido lático é incapaz de reduzir a população de leveduras em silagens (Bolsen et al., 1992; Ranjit \& Kung Jr., 2000). Higginbothan et al. (1998) não observaram feito sobre a população de leveduras em silagem de milho, com a aplicação de inoculante contendo $L$. plantarum $\left(1,5 \times 10^{4} \mathrm{ufc} / \mathrm{t} \mathrm{MV}\right)$ e $P$. cerevisae $\left(3 \times 10^{5} \mathrm{ufc} / \mathrm{g}\right)$, tendo constatado que a silagem inoculada apresentou teor de etanol duas vezes superior ao do controle (2,14 vs $1,04 \%$ da MS).

Deve-se considerar que neste experimento obteve-se concentração de etanol aproximadamente três vezes maior para o tratamento contendo L. plantarum, em relação 
ao controle (Tabela 4), sugerindo que estas bactérias dominaram o início do processo fermentativo, restringindo assim o desenvolvimento das bactérias heterofermentativas produtoras de ácido acético, aumentando a concentração de ácido lático em relação ao ácido acético na silagem, favorecendo assim o desenvolvimento das leveduras, já que o ácido lático possui menos da metade do poder fungicida do ácido acético (Moon, 1983)

Tabela 4. Parâmetros de fermentação, de digestibilidade e de avaliação das perdas durante a ensilagem da cana-de-açúcar, sob o efeito de inoculantes microbianos e aditivos químicos ${ }^{1}$

\begin{tabular}{|c|c|c|c|c|c|c|}
\hline \multirow[t]{2}{*}{ Tratamentos $^{2}$} & \multirow[t]{2}{*}{$\mathrm{pH}$} & Etanol & $\begin{array}{c}\text { Perda de } \\
\text { gases }\end{array}$ & $\begin{array}{c}\text { Perda total } \\
\text { de MS }\end{array}$ & DVIVMS & \multirow{2}{*}{$\begin{array}{l}\text { Efluente } \\
\mathrm{kg} / \mathrm{t} \mathrm{MV}\end{array}$} \\
\hline & & \multicolumn{2}{|c|}{$\% \mathrm{MS}$} & \multicolumn{2}{|c|}{$\%$} & \\
\hline Controle & $3,69^{\text {de }}$ & $3,82^{\mathrm{C}}$ & $10,3^{a b}$ & $18,2^{a b}$ & $45,4^{\mathrm{e}}$ & $15,1^{\mathrm{C}}$ \\
\hline Uréia $0,5 \%$ & $3,67^{\text {de }}$ & $4,20^{\mathrm{c}}$ & $8,10^{b c}$ & $12,2^{\mathrm{cd}}$ & $50,3^{\mathrm{cd}}$ & $28,5^{\mathrm{ab}}$ \\
\hline Uréia $1,0 \%$ & 3,72 de & $4,09^{c}$ & $8,56^{\mathrm{bc}}$ & $7,59^{d}$ & $50,2^{\mathrm{cd}}$ & $32,2^{a}$ \\
\hline Uréia $1,5 \%$ & $3,83^{\mathrm{d}}$ & $3,47^{\mathrm{c}}$ & $11,9^{a b}$ & $6,56^{\mathrm{d}}$ & $49,3^{\mathrm{cd}}$ & $26,0^{\mathrm{ab}}$ \\
\hline $\mathrm{NaOH} 1 \%$ & $4,31^{\mathrm{c}}$ & $2,44^{\mathrm{c}}$ & $6,85^{b c}$ & $8,91^{\mathrm{d}}$ & $54,8^{\mathrm{b}}$ & $6,53^{d}$ \\
\hline $\mathrm{NaOH} 2 \%$ & $5,08^{b}$ & $2,40^{\mathrm{c}}$ & $4,78^{\mathrm{c}}$ & $11,7^{\mathrm{cd}}$ & $65,4^{\mathrm{a}}$ & $5,98^{d}$ \\
\hline $\mathrm{NaOH} 3 \%$ & $5,78^{\mathrm{a}}$ & $2,44^{\mathrm{c}}$ & $4,93^{c}$ & $12,1^{\mathrm{cd}}$ & $67,3^{a}$ & $6,41^{d}$ \\
\hline Benzoato $0,05 \%$ & 3,60 de & $3,70^{\mathrm{c}}$ & $9,60^{b c}$ & $18,1^{\mathrm{ab}}$ & $48,2^{\mathrm{d}}$ & $22,8^{b}$ \\
\hline Benzoato $0,1 \%$ & $3,66^{\text {de }}$ & $2,52^{\mathrm{c}}$ & $9,83^{b}$ & $16,9^{b}$ & $49,8^{\mathrm{cd}}$ & $26,9^{\mathrm{ab}}$ \\
\hline Benzoato $0,2 \%$ & $3,83^{\mathrm{d}}$ & $2,03^{c}$ & $5,94^{b c}$ & $14,0^{b c}$ & $51,8^{\mathrm{c}}$ & $25,8^{b}$ \\
\hline Propionato $0,05 \%$ & $3,68^{\text {de }}$ & $6,81^{b c}$ & $12,2^{a b}$ & $13,6^{b c}$ & $45,7^{\text {de }}$ & $25,0^{\mathrm{b}}$ \\
\hline Propionato $0,1 \%$ & $3,65^{\text {de }}$ & $7,30^{\mathrm{b}}$ & $12,1^{a b}$ & $20,1^{\mathrm{ab}}$ & $44,4^{\mathrm{e}}$ & $28,7^{\mathrm{ab}}$ \\
\hline Propionato $0,2 \%$ & $3,71^{\text {de }}$ & $4,77^{b c}$ & $10,3^{a b}$ & $15,8^{b c}$ & $46,0^{\mathrm{de}}$ & $23,1^{\mathrm{b}}$ \\
\hline Sorbato $0,015 \%$ & $3,68^{\text {de }}$ & $3,05^{\mathrm{c}}$ & $12,7^{\mathrm{ab}}$ & $15,4^{\mathrm{bc}}$ & $47,1^{\text {de }}$ & $14,8^{\mathrm{c}}$ \\
\hline Sorbato $0,03 \%$ & $3,71^{\text {de }}$ & $1,79^{\mathrm{c}}$ & $7,75^{\mathrm{bc}}$ & $11,2^{\mathrm{cd}}$ & $48,1^{\text {de }}$ & $11,4^{\mathrm{cd}}$ \\
\hline Sorbato $0,045 \%$ & 3,59 de & $2,87^{\mathrm{c}}$ & $8,17^{\text {bc }}$ & $17,0^{\mathrm{b}}$ & $50,6^{\mathrm{cd}}$ & $21,6^{\mathrm{bc}}$ \\
\hline L. buchneri $3,64 \times 10^{5} \mathrm{ufc} / \mathrm{g} \mathrm{MV}$ & $3,52^{\mathrm{e}}$ & $1,95^{\mathrm{c}}$ & $8,93^{b c}$ & $8,05^{\mathrm{d}}$ & $48,0^{\text {de }}$ & $22,8^{b}$ \\
\hline L. plantarum $1 \times 10^{6} \mathrm{ufc} / \mathrm{g} \mathrm{MV}$ & $3,58^{\mathrm{de}}$ & $12,5^{\mathrm{a}}$ & $14,8^{\mathrm{a}}$ & $21,5^{\mathrm{a}}$ & $41,2^{f}$ & $29,9^{\mathrm{ab}}$ \\
\hline Lact/Ur $0,5 \%$ & $3,74^{\text {de }}$ & $6,17^{\mathrm{bc}}$ & $13,7^{\mathrm{ab}}$ & $12,7^{\mathrm{c}}$ & $45,6^{\mathrm{de}}$ & $26,3^{a b}$ \\
\hline Lact/Ur $1,0 \%$ & $3,71^{\text {de }}$ & $6,29^{b c}$ & $10,1^{b}$ & $11,4^{\mathrm{cd}}$ & $45,3^{\mathrm{e}}$ & $14,8^{\mathrm{c}}$ \\
\hline Média & 3,88 & 4,23 & 9,58 & 13,6 & 49,7 & 20,8 \\
\hline$E P M$ & 0,06 & 0,53 & 0,90 & 0,68 & 0,54 & 1,22 \\
\hline Efeitos & & & & & & \\
\hline Trat. & ** & $* *$ & $* *$ & $* *$ & ** & $* *$ \\
\hline Per. & $n s$ & $*$ & ** & $* *$ & ** & $* *$ \\
\hline Trat x per & ** & $n s$ & $*$ & $* *$ & $n s$ & $* *$ \\
\hline
\end{tabular}


No entanto, a aplicação de bactérias homoláticas L. plantarum e E. faecium foi capaz de diminuir a produção de etanol (1,3 vs 6,3\% da MS) e as perdas de MS (2,6 vs 7,4\%) em um experimento realizado por Driehuis and Wikselaar (2000) com silagens de capim azevém (L. perenne) emurchecido ( $48 \%$ de MS), embora não tenham sido identificados os microrganismos responsáveis pela fermentação alcoólica nas silagens.

O segundo maior valor numérico para a concentração de etanol ocorreu na silagem tratada com $0,1 \%$ de propionato e foi também acompanhado por redução acentuada $(22,4 \%)$ na DVIVMS em relação ao material original $(44,4$ vs 57,2$)$ e elevadas perdas de MS na forma de gases e efluentes (Tabelas 1 e 2). Os três tratamentos com propionato tiveram, em média, teor de etanol de 6,29\%, redução na DVIVMS de $19,3 \%$ e perdas totais de MS de $14,5 \%$, não tendo apresentado diferença entre si para estes parâmetros $(\mathrm{P}>0,05)$. Kung, Jr. et al. (2000) obtiveram diminuição do teor de etanol em silagem de milho tratada com $0,2 \%$ de ácido propiônico tamponado, mas não detectaram efeito para doses de 0,1 e 0,3\% do ácido. Ranjit \& Kung, Jr. (2000) relataram ausência de efeito sobre a população de leveduras, com a aplicação de 0,1\% de um produto comercial contendo ácido propiônico tamponado em silagens de milho, porém não foi avaliado o efeito sobre a produção de etanol.

Os resultados deste experimento indicam que as concentrações normalmente utilizadas de propionato são insuficientes para o controle de leveduras, e estão de acordo com dados obtidos em testes de laboratório onde constatou-se que a concentração de ácido propiônico necessária para a inibição do desenvolvimento destes microrganismos é de aproximadamente $60 \mathrm{mmol} /$ litro meio de cultura, em pH 4 (Moon, 1983; Woolford, 1975), equivalente a 4,7 g/litro de meio de cultura. Tendo em vista que a concentração máxima de propionato aqui avaliada $(0,2 \%)$ corresponde a 2,7 g/litro de água contida na forragem (considerando-se $25 \%$ de MS na silagem) é compreensível que não tenha havido controle na produção de etanol nas silagens. Por outro lado, o motivo do aumento na produção de etanol, advindo da aplicação da dose intermediária do sal de ácido propiônico (Tabela 4), não pode ser explicado com os dados disponíveis. Pode-se levantar a hipótese de que a sub-dosagem do ácido possa ter controlado alguns tipos de bactérias, que deixaram de competir com as leveduras favorecendo a produção do 
álcool. Isto pode ter ocorrido porque os níveis utilizados do ácido estiveram abaixo do indicado (Woolford, 1975) para inibição de leveduras mas estiveram acima do necessário para o controle de clostridia e, quando aplicado na maior dosagem, de varias espécies de bactérias heteroláticas.

Esperava-se que a inoculação com L. buchneri levasse à redução significativa na produção do álcool pela inibição do desenvolvimento das leveduras, que são normalmente controladas por concentrações de ácido acético acima de 5,6 g/litro do meio de cultura (94 mmol/litro) (Woolford, 1975). A expectativa foi baseada no fato de que $2 \%$ de ácido acético na MS, equivalente a 6,7 g do ácido por litro da fase líquida de uma forragem com $25 \%$ de MS, já seria suficiente para o controle de leveduras, e que a aplicação destas bactérias tem resultado em silagens com 3,6 a 4,98\% desse ácido na MS (Ranjit and Kung, Jr., 2000; Driehuis et al, 2001; Taylor et al., 2002). Tendo em vista que o inoculante causou redução de aproximadamente 50\% no valor numérico da concentração de etanol, em relação à silagem controle, pode-se considerar que a ausência de diferença significativa $(P>0,05)$ foi decorrente da variação relativamente alta encontrada na análise estatística deste parâmetro (média $=4,23 ; \mathrm{EPM}=0,53$ ) (Tabela 4).

Na Tabela 4 pode-se constatar que a aplicação do inoculante contendo $L$. buchneri reduziu em $56 \%$ a perda total de matéria seca da silagem em relação à silagem controle, embora a produção de efluentes tenha sido $51 \%$ maior $(\mathrm{P}<0,05)$. Utilizando-se os dados da Tabelas 1 e 2, pode-se calcular que a cana-de-açúcar inoculada com a bactéria heterolática apresentou redução menor na DVIVMS durante a ensilagem, quando comparada ao controle (12,7 vs 14,7\%).

Pode-se concluir que, embora o nível de aplicação do inoculante $\left(3,64\right.$ x $10^{5} \mathrm{ufc} / \mathrm{g}$ MV) não tenha sido suficiente para diminuir significativamente a produção de etanol, indicando que seu efeito sobre a população de leveduras foi restrito, a dosagem foi capaz de promover melhor conservação da silagem. Devendo-se ressaltar que outros pesquisadores só obtiveram redução sobre a população de leveduras com aplicações de L. buchneri na ordem de $10^{6}$ ufc/g (Driehuis et al., 1999; Ranjit \& Kung, Jr., 2000).

Os níveis de perda de MS das silagens tratadas com uréia ficaram situados entre os mais baixos observados neste experimento, embora as concentrações de etanol 
tenham sido semelhantes ao controle $(\mathrm{P}>0,05)$ e os níveis de produção de efluentes tenham estado entre os mais altos observados (Tabela 4). Os teores de FDN e FDA sofreram acréscimos insignificantes durante a conservação das silagens e foram aproximadamente $10 \%$ inferiores $(\mathrm{P}<0,05)$ aos da silagem controle (Tabela 5). De forma

Tabela 5. Parâmetros químicos das silagens de cana-de-açúcar, sob o efeito de aditivos químicos e inoculantes microbianos ${ }^{1}$

\begin{tabular}{|c|c|c|c|c|c|c|}
\hline \multirow[t]{2}{*}{ Tratamentos $^{2}$} & \multirow{2}{*}{$\begin{array}{c}\text { MS Final } \\
\%\end{array}$} & PB & FDN & FDA & Lignina & Cinza \\
\hline & & \multicolumn{5}{|c|}{$\% \mathrm{MS}$} \\
\hline Controle & $25,4^{\mathrm{d}}$ & $4,34^{\mathrm{eI}}$ & $64,5^{b}$ & $44,3^{\mathrm{bc}}$ & $7,86^{\mathrm{c}}$ & $6,97^{c}$ \\
\hline Uréia $0,5 \%$ & $26,7^{c}$ & $9,87^{\mathrm{d}}$ & $57,7^{\mathrm{cd}}$ & $39,7^{\mathrm{d}}$ & $7,03^{\mathrm{d}}$ & $6,07^{\mathrm{d}}$ \\
\hline Uréia $1,0 \%$ & $27,3^{b c}$ & $16,6^{b}$ & $58,2^{\mathrm{cd}}$ & $39,9^{\mathrm{d}}$ & $7,14^{d}$ & $6,01^{d}$ \\
\hline Uréia $1,5 \%$ & $26,4^{c}$ & $22,7^{\mathrm{a}}$ & $56,8^{\mathrm{d}}$ & $40,6^{\mathrm{d}}$ & $7,55^{\mathrm{cd}}$ & $5,50 \mathrm{de}$ \\
\hline $\mathrm{NaOH} 1 \%$ & $27,5^{\mathrm{bc}}$ & $3,89^{\mathrm{fg}}$ & $55,4^{\mathrm{d}}$ & $40,8^{d}$ & $7,04^{d}$ & $9,12^{b}$ \\
\hline $\mathrm{NaOH} 2 \%$ & $27,3^{b c}$ & $2,87^{\mathrm{g}}$ & $47,3^{\mathrm{e}}$ & $36,7^{\mathrm{e}}$ & $5,94^{\mathrm{e}}$ & $11,0^{\mathrm{a}}$ \\
\hline $\mathrm{NaOH} 3 \%$ & $29,2^{\mathrm{a}}$ & $2,82^{g}$ & $44,8^{\mathrm{e}}$ & $36,4^{\mathrm{e}}$ & $5,91^{\mathrm{e}}$ & $11,2^{\mathrm{a}}$ \\
\hline Benzoato $0,05 \%$ & $26,0^{\mathrm{cd}}$ & $3,91^{\mathrm{fg}}$ & $60,9^{c}$ & $41,8^{\mathrm{cd}}$ & $7,40^{\mathrm{cd}}$ & $6,13^{d}$ \\
\hline Benzoato $0,1 \%$ & $26,5^{c}$ & $3,64^{\mathrm{fg}}$ & $60,0^{\mathrm{cd}}$ & $41,5^{\mathrm{cd}}$ & $7,22^{d}$ & 5,49 de \\
\hline Benzoato $0,2 \%$ & $27.5^{\mathrm{bc}}$ & $3,36^{\mathrm{fg}}$ & $57,1^{\mathrm{d}}$ & $41,0^{\mathrm{cd}}$ & $7,10^{\mathrm{d}}$ & $5,28^{\mathrm{e}}$ \\
\hline Propionato $0,05 \%$ & $25,1^{d}$ & 4,43 ef & $63,7^{b c}$ & $43,8^{b c}$ & 7,92 bc & $6,81^{\mathrm{cd}}$ \\
\hline Propionato $0,1 \%$ & $24,8^{\mathrm{d}}$ & $4,34^{\text {ef }}$ & $65,8^{a b}$ & $45,3^{b c}$ & $8,31^{b c}$ & $6,44^{\mathrm{cd}}$ \\
\hline Propionato $0,2 \%$ & $26,4^{c}$ & $3,84^{\mathrm{fg}}$ & $63,8^{\mathrm{bc}}$ & 44,1 bc & $7,98^{b c}$ & $6,80^{\mathrm{cd}}$ \\
\hline Sorbato $0,015 \%$ & $28,0^{\mathrm{b}}$ & $4,00^{\mathrm{f}}$ & $62,7^{\mathrm{bc}}$ & $43,1^{\mathrm{c}}$ & $7,51^{\mathrm{cd}}$ & $6,95^{\mathrm{c}}$ \\
\hline Sorbato $0,03 \%$ & $28,8^{a b}$ & $4,19^{\text {ef }}$ & $61,6^{\mathrm{bc}}$ & $42,8^{\mathrm{cd}}$ & $7,38^{\mathrm{cd}}$ & $6,83^{\mathrm{cd}}$ \\
\hline Sorbato $0,045 \%$ & $26,1^{\mathrm{cd}}$ & $3,64^{\mathrm{fg}}$ & $59,5^{\mathrm{cd}}$ & $40,3^{\mathrm{d}}$ & $6,94^{\mathrm{d}}$ & $5,46^{\mathrm{de}}$ \\
\hline L. buchneri $3,64 \times 10^{5} \mathrm{ufc} / \mathrm{g} \mathrm{MV}$ & $26,5^{\mathrm{c}}$ & $4,09^{\text {ef }}$ & $60,6^{\mathrm{c}}$ & $41,0^{\mathrm{cd}}$ & $7,38^{\mathrm{cd}}$ & $5,91^{\mathrm{de}}$ \\
\hline L. plantarum $1 \times 10^{6}$ ufc/g $M V$ & $23,7^{\mathrm{e}}$ & $5,14^{\mathrm{e}}$ & $68,9^{\mathrm{a}}$ & $48,7^{\mathrm{a}}$ & $9,19^{\mathrm{a}}$ & $6,61^{\mathrm{cd}}$ \\
\hline Lact/Ur $0,5 \%$ & $24,5^{\text {de }}$ & $10,9^{\mathrm{d}}$ & $63,6^{\mathrm{bc}}$ & $45,4^{\mathrm{b}}$ & $8,25^{b c}$ & $6,26^{\mathrm{cd}}$ \\
\hline Lact/Ur $1,0 \%$ & $26,4^{c}$ & $15,4^{\mathrm{c}}$ & $62,8^{b c}$ & $45,7^{\mathrm{b}}$ & $8,50^{\mathrm{b}}$ & $6,65^{\mathrm{cd}}$ \\
\hline Média & 26,5 & 6,70 & 59,8 & 42,1 & 7,48 & 6,87 \\
\hline $\begin{array}{l}\text { EPM } \\
\text { Efeitos }\end{array}$ & 0,18 & 0,21 & 0,63 & 0,43 & 0,12 & 0,14 \\
\hline Trat. & $* *$ & $* *$ & $* *$ & $* *$ & $* *$ & $* *$ \\
\hline Per. & $* *$ & $n s$ & $* *$ & $* *$ & $* *$ & $n s$ \\
\hline Trat x per & ** & 0,06 & $n s$ & $n s$ & $n s$ & $n s$ \\
\hline
\end{tabular}

coerente com o pequeno aumento observado na fração fibrosa da forragem, os valores de DVIVMS destas silagens mostraram reduções entre 0,4 e 4,3\%, em relação à digestibilidade original da cana (cálculo com base nos dados das Tabelas 1 e 2). Lima et 
al. (2002) relataram reduções de 49 e 37\%, respectivamente para FDN e FDA de silagens tratadas com 0,1 e 1,5\% de uréia, em relação à silagem sem aditivo.

$\mathrm{O}$ tratamento com uréia resultou em silagens com $\mathrm{pH}$ dentro de um patamar adequado à conservação (Tabela 4), uma vez que silagens de boa qualidade podem apresentar pH variando entre 3,6 e 4,2 (McDonald et al., 1991), sendo que a silagem tratada com $0,5 \%$ de uréia apresentou $\mathrm{pH}$ próximo ao encontrado por Molina et al. (2002) em cana-de-açúcar ensilada com a mesma dose do aditivo $(3,6)$. O teor de PB das silagens (Tabela 5) correspondeu ao esperado com a adição dos diferentes níveis de uréia, indicando recuperação elevada do nitrogênio aplicado.

A adição de uréia juntamente com bactérias homoláticas, tratamentos Lact/Ur 0,5\% e Lact/Ur 1,0\%, resultou em produções de etanol e perdas totais de MS iguais $(\mathrm{P}>0,05)$ aos das silagens tratadas com as doses correspondentes de uréia exclusiva, indicando que não houve benefício da ação conjunta dos aditivos. A ação das bactérias homoláticas não reduziu o $\mathrm{pH}$ destas silagens a níveis mais baixos que os das silagens tratadas apenas com uréia $(\mathrm{P}>0,05)$ (Tabela 4). Os dados disponíveis não permitem explicar a redução na produção de efluentes observada para o tratamento Lact/Ur 1,0\% (Tabela 4), tendo em vista que o teor de MS da silagem (Tabela 5) foi semelhante ao de outros tratamentos onde houve maior produção de efluentes.

Os tratamentos com $\mathrm{NaOH}$ resultaram em silagens com teores de etanol semelhantes ao controle $(\mathrm{P}>0,05)$ e perdas totais de MS dentro dos níveis mais baixos observados neste trabalho, apesar das silagens terem apresentado $\mathrm{pH}$ acima do nível máximo considerado adequado à estabilização de forragens ensiladas. As produções de efluentes foram as menores $(\mathrm{P}<0,05)$ observadas. As DVIVMS foram as maiores $(\mathrm{P}<0,05)$ entre todos os tratamentos utilizados, sendo que as doses de 2 e $3 \%$ do álcali produziram silagens com digestibilidade maior $(\mathrm{P}<0,05)$ do que a que recebeu dose de $1 \%$, e foram em média $46 \%$ mais digestíveis do que a silagem controle (Tabela 4). Com base nos dados das Tabelas 1 e 2 pode-se estimar que, as doses de 1, 2 e 3\% de $\mathrm{NaOH}$ promoveram, respectivamente, reduções de 14, 7 e 5\%, nas DVIVMS das forragens durante o período de ensilagem. De forma coerente com a maior digestibilidade das silagens, os tratamentos com 2 e $3 \%$ de $\mathrm{NaOH}$ resultaram em silagens com as menores 
$(\mathrm{P}<0,05)$ concentrações de FDN, FDA e lignina (Tabela 5), sendo que a FDN não sofreu aumento e a FDA apresentou aumento aproximado 4\%, em relação à cana tratada antes da ensilagem (Tabela 3). A capacidade do $\mathrm{NaOH}$ em romper a estrutura e solubilizar componentes da parede celular (Mattos, 1985), compensou em grande parte o aumento que deveria ser observado, na concentração destes nutrientes, em decorrência do consumo de CHOs durante a fermentação.

Reduções significativas na concentração de etanol de silagens de cana-de-açúcar tratadas com $\mathrm{NaOH}$, em concentrações variando entre 3 e $4 \%$ na MS, foram relatadas por Castrillón et al. (1978) e Alcántara et al. (1989), o que não foi obtido neste experimento. No entanto, o efeito do álcali sobre os componentes da fibra da silagem foi menor no trabalho de Alcántara et al. (1989), que obtiveram valores aproximados de $60 \%$ de FDN, 43\% de FDA e 10\% de lignina, para a silagem tratada com $3 \%$ de $\mathrm{NaOH}$, a partir de cana-de-açúcar contendo 50\% de FDN, 35\% de FDA e 7\% de lignina, aproximadamente. Deve-se levar em consideração no entanto que, apesar dos efeitos positivos que seu emprego possa apresentar, o hidróxido de sódio tem sofrido restrições de uso na ensilagem devido aos riscos inerentes à sua manipulação, à vida útil das máquinas e ao meio ambiente.

Os tratamentos com benzoato de sódio não reduziram a concentração de etanol e as perdas totais de MS das silagens em relação ao controle ( $\mathrm{P}>0,05)$ (Tabela 4). A dose maior do produto resultou no menor aumento da FDN em relação à forragem fresca (7\%). A menor redução no valor da digestibilidade $(7,2 \%)$, em relação à cana antes da ensilagem, ocorreu com o maior nível de inclusão do ácido, refletindo o menor acréscimo sofrido na FDN, indicando que deve ter ocorrido menor perda de nutrientes solúveis para este tratamento. As perdas por efluentes foram acentuadas $(25,2 \mathrm{~kg} / \mathrm{t} \mathrm{em}$ média) e maiores que a do controle $(\mathrm{P}<0,05)$, apesar do teor de MS final ter sido, em média, mais elevado nas silagens tratadas com benzoato.

São escassos os trabalhos de pesquisa com aditivos contendo benzoato de sódio. Lättemäe e Lingvall (1996) obtiveram efeito positivo com a aplicação de 0,15\% de benzoato em silagens de capim emurchecido, através de um aditivo contendo também nitrito de sódio e hexamina. Foi observado efeito benéfico sobre a conservação das 
silagens, com maior teor de carboidratos solúveis (68 vs $11 \%$ da MS), resultando em silagens com MS mais elevada (40 x 36\%), em comparação com a silagem sem aditivo.

A aplicação do sorbato de potássio não foi capaz de reduzir o teor de etanol e de melhorar a DVIVMS das silagens em relação à silagem sem aditivo $(\mathrm{P}>0,05)$. A dose intermediária do produto, no entanto, reduziu as perdas totais de MS em aproximadamente 39\% e resultou em menor perda no valor da DVIVMS durante o período de conservação, (9,2 vs 14,7\%), em relação ao controle. A produção de efluentes da silagem deste tratamento foi semelhante ao controle, embora os teores de MS final da silagem tenha sido mais elevado $(\mathrm{P}<0,05)$.

Tabela 6. Efeito do período de conservação sobre os valores médios dos parâmetros de fermentação, de valor nutritivo e de perdas de MS, em silagens de cana-deaçúcar tratadas com aditivos químicos ${ }^{1}$, inoculantes microbianos ${ }^{2} \mathrm{e}$ combinações entre eles ${ }^{3}$

\begin{tabular}{|c|c|c|c|c|c|}
\hline \multirow[t]{2}{*}{ Parâmetro } & \multicolumn{2}{|c|}{ Dias após a ensilagem } & \multirow[t]{2}{*}{ Média } & \multirow[t]{2}{*}{$E P M$} & \multirow[t]{2}{*}{ Efeito } \\
\hline & 90 dias & 180 dias & & & \\
\hline Etanol (\% MS) & 4,47 & 3,98 & 4,23 & 0,17 & $*$ \\
\hline Perda total de MS (\%) & 12,2 & 15,1 & 13,6 & 0,22 & $* *$ \\
\hline $\operatorname{DVIVMS}(\%)$ & 50,7 & 48,8 & 49,7 & 0,17 & $* *$ \\
\hline Perda de gases (\% MS) & 8,64 & 10,5 & 9,58 & 0,29 & $* *$ \\
\hline Efluente (kg/t MV) & 15,6 & 25,8 & 20,8 & 0,39 & $* *$ \\
\hline $\mathrm{pH}$ & 3,90 & 3,87 & 3,88 & 0,02 & $n s$ \\
\hline MS final (\%) & 26,7 & 26,3 & 26,5 & 0,06 & $* *$ \\
\hline FDN (\% MS) & 59,3 & 60,2 & 59,8 & 0,20 & $* *$ \\
\hline FDA (\% MS) & 41,5 & 42,7 & 42,1 & 0,14 & $* *$ \\
\hline Lignina (\% MS) & 7,25 & 7,71 & 7,48 & 0,04 & $* *$ \\
\hline Cinzas (\% MS) & 6,87 & 6,88 & 6,87 & 0,04 & $n s$ \\
\hline $\mathrm{PB}(\% \mathrm{MS})$ & 6,72 & 6,67 & 6,70 & 0,07 & $n s$ \\
\hline
\end{tabular}

Apesar de as doses utilizadas do sorbato não terem sido capazes de eliminar a produção de etanol ou reduzi-la em relação à cana-de-açúcar ensilada pura, Weinberg et al. (1989) constataram redução de $47 \%$ no teor do álcool ( 8,30 vs $15,7 \%$ da MS) e menor perda de carboidratos solúveis, em silagem de polpa úmida de laranja tratada com $0,05 \%$ de sorbato de potássio. Esses pesquisadores comentaram que o aditivo não 
causou redução significativa na contagem de leveduras e que o efeito, portanto, deve ter sido apenas de inibição da atividade destes microrganismos, e não de eliminação dos mesmos.

Na Tabela 6 pode-se observar que a concentração de etanol foi $11 \%$ menor aos 180 dias $(\mathrm{P}<0.05)$, sugerindo intensificação nas perdas por volatilização do álcool. As perdas geradas por gases e efluentes foram, respectivamente, 22 e $65 \%$ maiores aos 180 dias de conservação, resultando em perda total de MS 24\% maior, em relação à perda aos 90 dias $(\mathrm{P}<0,01)$. Nota-se que apesar da produção de efluentes ter sido crescente até os 180 dias de conservação, a perda de MS por lixiviação foi pequena em relação às perdas gasosas, que foram responsáveis por $70 \%$ da perda total de MS em ambos os períodos. A DVIVMS sofreu redução de aproximadamente 3,7\% dos 90 aos 180 dias, o que está de acordo com as observações deste projeto de pesquisa (capítulo 3), onde constatou-se que o consumo de carboidratos solúveis, e a perda no valor nutritivo em silagem de cana-de-açúcar, ocorrem quase que totalmente antes dos 60 dias de estocagem. Esse fato sugere que, uma porção significativa das perdas gasosas ocorridas após este período de estocagem deve ser devida a perdas por volatilização do etanol, com pouca influencia sobre a DVIVMS. O pH, a concentração de cinzas e de proteínas não sofreram alteração $(\mathrm{P}>0,05)$ entre os dois períodos considerados e os componentes da parede celular sofreram acréscimos com o aumento do período de estocagem $(\mathrm{P}<0,01)$ denotando as perdas de componentes solúveis. Deve-se levar em consideração que os valores elevados das médias dos teores de proteína bruta das silagens, nos dois períodos, ocorreram em consequiência das altas concentrações obtidas nos tratamentos com uréia.

\subsubsection{Efeito dos tratamentos sobre a estabilidade aeróbica das silagens}

Nas Figuras 1, 2 e 3 pode-se notar que o valor de estabilidade aeróbica propriamente dita, estabelecido como o intervalo de tempo decorrido entre o momento da exposição das silagens ao ar e o momento onde ocorreu uma diferença mínima de $2{ }^{\circ} \mathrm{C}$ entre a temperatura da massa de silagem e a temperatura ambiente (referência), 
sofreu grande influência do tipo de tratamento imposto à silagem. Da mesma forma, houve diferenças marcantes entre os tratamentos para o ADITE-5 (vide item 4.2.5).

Na Figura 5 observa-se que a silagem controle apresentou estabilidade aeróbica de 65 horas e ADITE-5 de $36{ }^{\circ} \mathrm{C}$. Não foram encontrados dados relativos à estabilidade aeróbica de silagens de cana-de-açúcar para que fosse possível estabelecer comparações. Para silagens de milho, valores como 27 horas (Ranjit \& Kung, Jr., 2000) e 43 horas de estabilidade (Driehuis et al., 1999), para silagens contendo 3,7 e 6,9\% de CHOs residuais, respectivamente, têm sido relatados. Considerando-se que estudos prévios indicaram que o teor de CHOs residuais em silagem de cana-de-açúcar pode ser de 6,3\% da MS (capítulo 3), não seria errada a sugestão de que a estabilidade aeróbica obtida neste trabalho, para a silagem controle, foi relativamente elevada. Contudo, a comparação de dados de estabilidade aeróbica deve ser feita com cautela, em decorrência de variações entre experimentos de fatores como: temperatura de referência adotada, tamanho da alíquota tomada para teste, população de leveduras existente na forragem e condições ambientais. Levando-se em conta que a estabilidade aeróbica varia

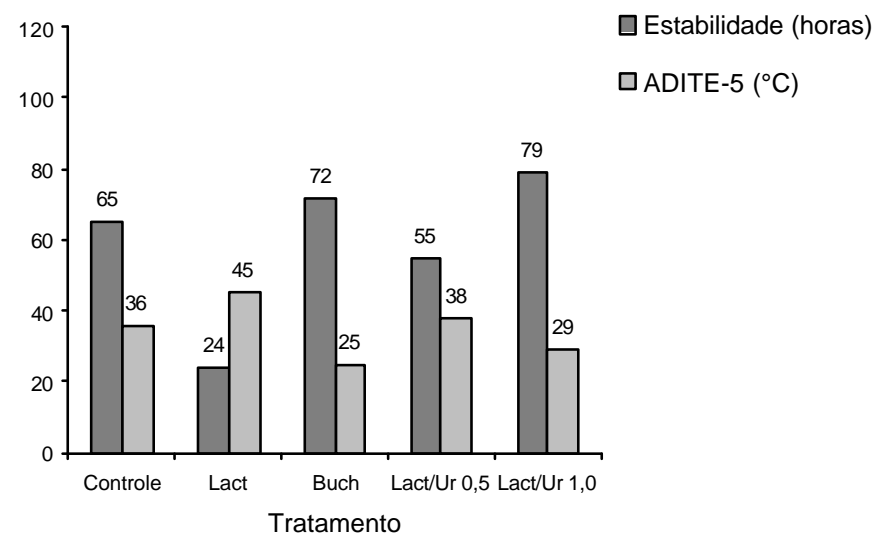

Figura 5 - Estabilidade aeróbica e ADITE- $5^{*}$ em silagens de cana-de-açúcar sob o efeito da inoculação com L. plantarum (Lact), L. buchneri (Buch) e das combinações de L. plantarum com uréia (Lact/Ur 0,5 e Lact/Ur 1,0)

* Acúmulo da diferença média, entre a temperatura ambiente e a temperatura das silagens, nos primeiros 5 dias de exposição ao ar. 
em função de diversos fatores, como os teores de MS, de carboidratos solúveis residuais, da concentração dos ácido acético e butírico e da contagem de leveduras nas silagens (McDonald et al., 1991), torna-se difícil identificar o motivo do valor relativamente alto da estabilidade neste caso. Pode-se, no entanto, levantar a hipótese de que o etanol, que tem poder fungicida acima de certa concentração (Gutierres,1991; Driehuis \& Wikselaar, 2000), foi responsável pela inibição do desenvolvimento das leveduras e mofos, aumentando a estabilidade aeróbica da silagem.

A inoculação com L. plantarum (1 x $10^{6}$ ufc/g MV) ocasionou redução de $63 \%$ na estabilidade, e aumento de $26 \%$ no ADITE-5, da silagem em relação ao controle (Figura 5). Os resultados de diversos trabalhos mostram que a inoculação com esta

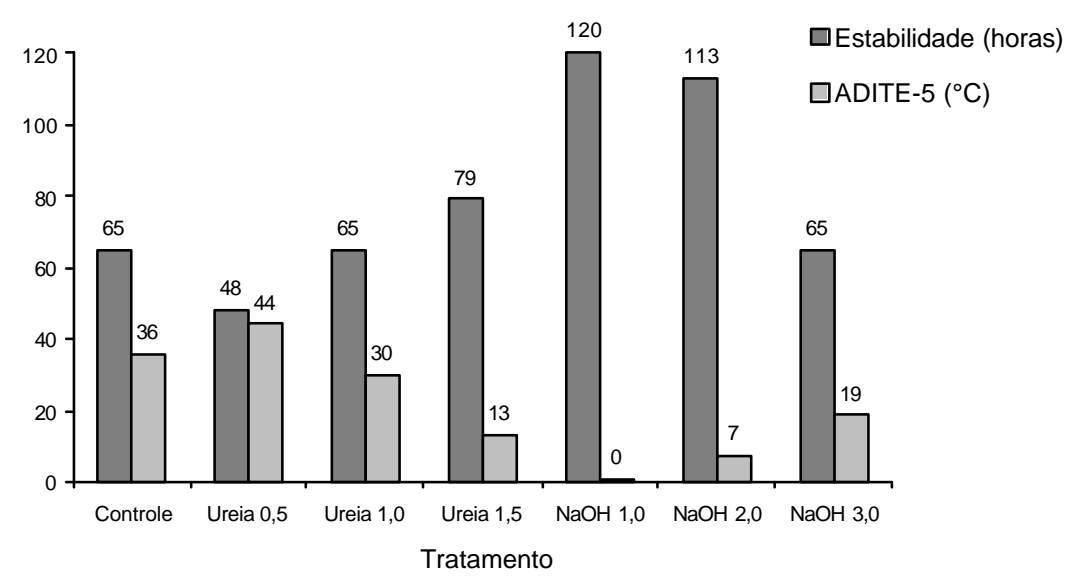

Figura 6 - Estabilidade aeróbica e ADITE- $5^{*}$ de silagens de cana-de-açúcar sob o efeito dos tratamentos com uréia e $\mathrm{NaOH}$, em diversas concentrações

* Acúmulo da diferença média, entre a temperatura ambiente e a temperatura das silagens, nos primeiros 5 dias de exposição ao ar.

bactéria homolática, na ordem de $1,5 \times 10^{4}$ a 1 x $10^{6} \mathrm{ufc} / \mathrm{g}$, normalmente causa pequena ou nenhuma melhora na estabilidade aeróbica das silagens tratadas (Higginbothan et al., 1998; Ranjit \& Kung, 2000) sendo que sua ação caracteriza-se pela queda mais rápida do $\mathrm{pH}$, diminuindo o período de fermentação e as perdas de MS, resultando em silagens com maiores teores de $\mathrm{CHOs}$ residuais. Como a inoculação com estas bactérias ocasiona 
normalmente menor produção de ácido acético, que tem efeito fungicida, e maior produção de ácido lático, que serve de substrato para microrganismos aeróbicos, juntamente com os CHOs solúveis residuais (McDonald et al., 1991), estas silagens tornam-se instáveis na presença de oxigênio.

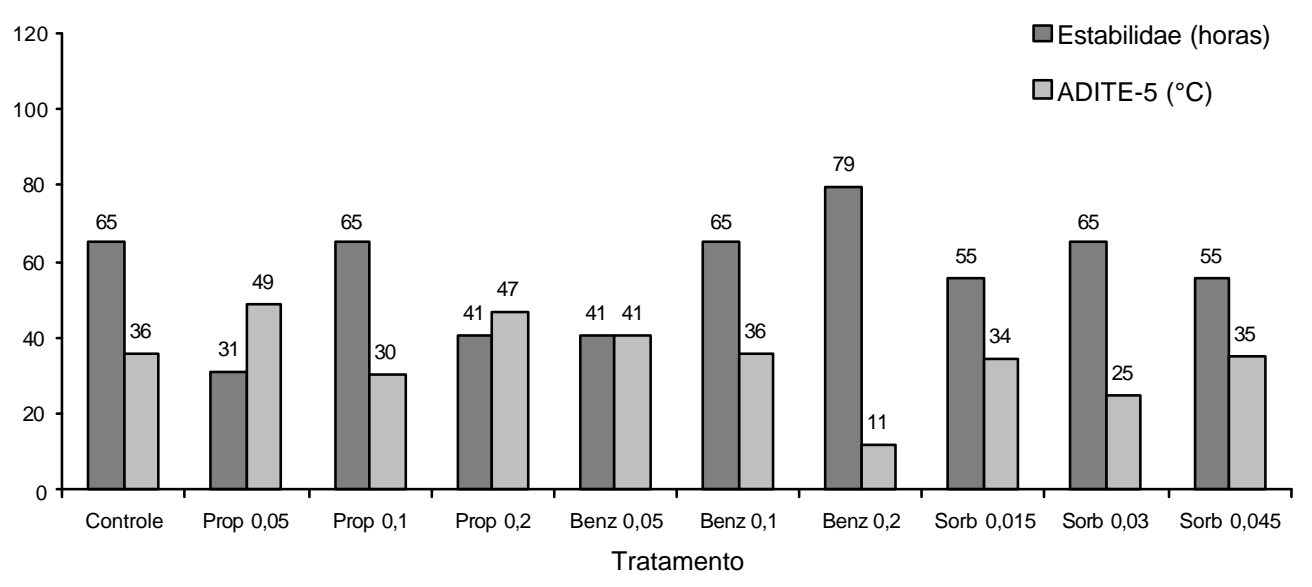

Figura 7 - Estabilidade aeróbica e ADITE- $5^{*}$ de silagens de cana-de-açúcar sob o efeito dos tratamentos com propionato de cálcio (Prop), benzoato de sódio (Benz) e sorbato de potássio (Sob), em diversas concentrações

* Acúmulo da diferença média, entre a temperatura ambiente e a temperatura das silagens, nos primeiros 5 dias de exposição ao ar.

A aplicação combinada de L. plantarum com 0,5 e 1,0\% de uréia (Lact/Ur 0,5 e Lact/Ur 1,0) resultou em silagens que apresentaram, respectivamente, estabilidades $15 \mathrm{e}$ $22 \%$ maiores e ADITE-5 15 e $2 \%$ menores do que os tratamentos onde a uréia foi aplicada pura, nas mesmas concentrações. Pode-se notar que o tratamento Lact/Ur 1,0 resultou em estabilidade igual ao tratamento com 1,5\% de uréia, no entanto, apresentou ADITE-5 aproximadamente 2 vezes maior (Figuras 1 e 2).

A aplicação do inoculante contendo L. buchneri resultou em silagens com estabilidade aeróbica $11 \%$ maior e ADITE-5 30\% menor, em relação ao tratamento controle (Figura 5). Efeitos positivos da adição desta bactéria heterolática sobre os 
parâmetros de avaliação de estabilidade aeróbica têm sido relatados de forma consistente. Os resultados obtidos neste experimento, onde as bactérias foram adicionadas para atingir $3,64 \times 10^{5} \mathrm{ufc/g}$ de forragem, não foram tão favoráveis quanto os reportados por Driehuis et al. (1999) que, com a adição da bactéria na dose de 1 x $10^{6}$ ufc/g, obtiveram silagem de milho estável por mais de 792 horas, sendo que a silagem controle permaneceu estável por apenas 43 horas. Os resultados do presente experimento podem ser considerados superiores aos relatados por Ranjit \& Kung, Jr. (2000) que, para o nível de aplicação da bactéria de 1 x $10^{5}$ ufc/g, obtiveram silagem de milho com estabilidade de apenas 36 horas. No entanto, esses mesmos pesquisadores obtiveram silagem de milho estável por mais de 900 horas, com a aplicação do inoculante em dose suficiente para atingir 1 x $10^{6} \mathrm{ufc} / \mathrm{g}$ de forragem. Driehuis et al. (2001) obtiveram silagens de capim azevém (Lolium perenne) emurchecido, com estabilidade superior a 480 horas com a aplicação de L. buchneri em taxas de $1 \times 10^{5}$ e $3 \times 10^{5}$ ufc/g. No entanto, a silagem controle apresentou teor de ácido acético de 3,17\% na MS e estabilidade de 183 horas, sendo que os autores salientaram que a microflora epífita da silagem controle foi predominantemente representada por bactérias da espécie $L$. buchneri. Isto sugere que o nível de aplicação de $1 \times 10^{5} \mathrm{ufc/g}$ poderia não ter sido tão eficiente se não houvesse a ação conjunta das bactérias originalmente presentes na forragem.

Na Figura 6 pode-se constatar que a silagem tratada com a menor dose de uréia apresentou estabilidade aeróbica 25\% menor e ADITE-5 23\% maior do que o controle e que a silagem tratada com a maior dose resultou em estabilidade $22 \%$ maior e ADITE-5 $63 \%$ menor em relação à silagem não aditivada. Estes dados evidenciam o aumento do poder inibidor do desenvolvimento de leveduras, que são os principais agentes causadores da deterioração aeróbica, com o aumento da dose de uréia, de forma consistente com os dados da Tabela 4 que indicam tendência de redução nas perdas totais de MS e de menor concentração de etanol nas silagens, o que também indica maior ação sobre as leveduras, com o aumento da dose do aditivo. A capacidade da uréia em diminuir a população de leveduras e mofos, aumentando a estabilidade aeróbica das silagens, é bem conhecida (Rotz \& Muck, 1994; Bolsen et al., 1995), sendo que Britt \& 
Huber (1975) constaram que silagens de milho, tratadas com 0,5 e 1,0\% de uréia, demoraram 11 e 12 dias respectivamente, para apresentarem sinais visíveis de desenvolvimento de fungos, quando expostas ao ar.

A aplicação do $\mathrm{NaOH}$ por sua vez, resultou em efeito inverso ao da uréia, sobre a estabilidade das silagens, ou seja, houve diminuição da estabilidade e aumento dos ADITE-5s com o aumento da dose do álcali (Figura 6). A estabilidade da silagem tratada com a menor dose de $\mathrm{NaOH}$ foi $85 \%$ maior do que a da silagem controle, mantendo-se estável por 5 dias. Para a dose intermediária do produto, houve pequena redução na estabilidade e pequeno aquecimento da silagem durante os primeiros 5 dias de exposição ao ar, mas a aplicação da maior dose produziu silagem com estabilidade similar à do controle, mas com ADITE-5 47\% menor. Nas Tabelas 2 e 3 pode-se notar que o aumento das doses de $\mathrm{NaOH}$ resultou em maiores DVIVMS e menores teores de FDN e FDA, sugerindo que houve aumento da disponibilidade de CHOs, com o aumento da concentração do álcali. Estes fatos refletiram-se na diminuição da estabilidade com o aumento da quantidade de $\mathrm{NaOH}$ aplicado às silagens, provavelmente devido à maior disponibilidade de substrato para desenvolvimento dos microrganismos aeróbicos.

O sal de ácido propiônico, quando aplicado na dose de $0,1 \%$ na forragem, resultou em silagem com estabilidade e ADITE-5 semelhantes ao da silagem sem aditivos, no entanto, o aumento e a diminuição da dose, resultaram em silagens menos estáveis e que aqueceram mais durante os primeiros cinco dias de aeração (Figura 7). Os efeitos aqui obtidos, para a concentração de $0,1 \%$ do ácido, foram superiores aos relatados por Kung, Jr. et al. (2000) e Ranjit \& Kung, Jr. (2000) que relataram estabilidade de 37 horas em silagem de milho tratada com a mesma dose do produto, entretanto, Kung, Jr. et al. (2000) obtiveram aumento da estabilidade com o aumento da dose para $0,2 \%$, de modo inverso ao ocorrido no presente experimento, onde a maior concentração do ácido resultou em redução de $37 \%$ na estabilidade. Pode-se supor que tal fato tenha ocorrido porque a maior dose de propionato foi capaz de reduzir a perda de CHOs durante a fermentação (Tabela 4), mas não foi suficiente para conter o seu consumo pelos microrganismos, por muito tempo, na situação de aerobiose. 
O benzoato de sódio mostrou efeito crescente na estabilidade aeróbica com o aumento da sua concentração na silagem, contudo, apenas o tratamento com a maior dose promoveu melhoria na estabilidade em relação ao controle, com estabilidade $20 \%$ maior e ADITE-5 70\% menor (Figura 7). Os efeitos do benzoato, seguiram a tendência de aumento na inibição da fermentação alcoólica e de redução nas perdas de MS, com o aumento da dose do ácido obtidos durante a estocagem da silagem (Tabela 4). Lättemäe e Lingvall (1996), avaliando aditivos contendo benzoato de sódio combinado à hexamina na conservação de silagens de capim azevém emurchecido, observaram aumento significativo na estabilidade aeróbica com a aplicação $0,15 \%$ do ácido à silagem.

O efeito do sorbato de potássio sobre a estabilidade aeróbica da forragem (Figura 7), seguiu o mesmo padrão observado durante o período de ensilagem, ou seja, a dose intermediária propiciou o melhor valor de estabilidade aeróbica, da mesma forma que resultou nos menores valores numérico de perda de gases e de MS total. No entanto, nenhuma das doses empregadas mostrourse capaz de melhorar expressivamente a estabilidade em relação ao controle, embora tenha havido redução de $31 \%$ no ADITE-5, com o uso da dose de $0,03 \%$ do produto.

\subsection{Conclusões}

Aditivos são capazes de reduzir as perdas de MS e de valor nutritivo na ensilagem da cana-de-açúcar, aumentando também a sua estabilidade aeróbica.

A tomada de decisão pelo aditivo adequado é fundamental, do contrário existe a possibilidade de se obter efeitos opostos ao desejado, podendo ocorrer aumento da produção de etanol e da perda de valor nutritivo durante a estocagem das silagens.

Alguns aditivos foram eficientes em poupar carboidratos solúveis durante a fase de fermentação mas resultaram em silagens menos estáveis, quando estas foram expostas ao ar, indicando que, a escolha de aditivos deve considerar a conservação de nutrientes, desde a fase de fechamento dos silo até a oferta da silagem aos animais. 


\section{DINÂMICA DA FERMENTAÇÃO, DAS PERDAS DE MATÉRIA SECA E ESTABILIDADE AERÓBICA DE SILAGENS DE CANA-DE-AÇÚCAR TRATADAS COM ADITIVOS QUÍMICOS E MICROBIANOS}

\section{Resumo}

O objetivo deste experimento foi comparar o efeito de três aditivos químicos e dois inoculantes microbianos sobre a dinâmica da fermentação, perdas de matéria seca (MS) e da digestibilidade "in vitro" (DVIVMS) durante o processo de conservação de silagens de cana-de-açúcar e ainda determinar seus efeitos sobre a estabilidade aeróbica das silagens. A cana foi colhida após 12 meses de rebrota e ensilada em baldes de plástico de 20 litros adaptados, com válvulas para eliminação de gases, e dispositivo para colheita de efluentes. Os aditivos avaliados foram (\% na massa verde): uréia (0,5\%), benzoato de sódio-BENZ $(0,1 \%)$, sorbato de potássio-SORB $(0,03 \%), L$. plantarum-BAL (1 x $\left.10^{6} \mathrm{ufc/g}\right)$ e L. buchneri-BUCH (3,64 x $\left.10^{5} \mathrm{ufc} / \mathrm{g}\right)$. As silagens foram amostrados após 2, 10, 31, 62, 94 e 144 dias de fermentação. As perdas de MS total, de gases e de efluentes foram avaliadas por gravimetria e a estabilidade aeróbica pelo controle da temperatura das silagens expostas ao ar. A adição de uréia, BENZ, SORB e BUCH resultou em silagens com menor teor de etanol $(\mathrm{P}<0,05)$ em relação à silagem controle que foi de 4,05\% da MS, mas o tratamento BAL causou aumento na concentração do álcool. Uréia e SORB causaram aumentos $(\mathrm{P}<0,05)$ na perda total de MS em relação ao controle, que foi de 6,82\%. A aplicação de uréia resultou em aumento, e a inoculação com BAL em redução, na DVIVMS $(\mathrm{P}<0,05)$. O tratamento com BENZ resultou na silagem com maior $(\mathrm{P}<0,05)$ concentração de carboidratos solúveis $(13,4 \%$ da $\mathrm{MS})$. As curvas de regressão representando a tendência temporal 
indicaram que: a produção do álcool atingiu os pontos de maior concentração entre 60 e 90 dias de ensilagem; a perda de MS na forma de gases se prolongaram além dos 90 dias de ensilagem e foi menor para o tratamento com uréia; o tratamento com L. buchneri resultou em tendência de maior perda de açúcares ao longo do tempo; os tratamentos com uréia e sorbato, apesar de não terem apresentado os maiores níveis de perdas gasosas, foram os que acumularam as maiores perdas totais e apresentaram maior produção de efluentes; as DVIVMS das silagens dos tratamentos com uréia, benzoato e sorbato apresentaram tendência linear de diminuição com o passar do tempo, provavelmente como efeito de uma tendência de produção crescente de efluentes destas silagens. Os aditivos BENZ e BUCH melhoraram a estabilidade aeróbica das silagens, em relação ao tratamento controle (78 e 72 h vs 48 h).

\section{AEROBIC STABILITY, FERMENTATION AND DRY MATTER LOSSES DYNAMICS IN SUGAR CANE SILAGES TREATED WITH CHEMICAL AND MICROBIAL ADDITIVVES}

\section{Summary}

The major objective of this trial was to compare the effects of additives, screened in experiment II, on silage fermentation and DM losses dynamics and aerobic stability. Treatments were (wet basis): urea $(0.5 \%)$, sodium benzoate-BENZ $(0.1 \%)$, potassium sorbate-SORB $(0.03 \%)$, L. plantarum-LAB $\left(1 \times 10^{6} \mathrm{cfu} \mathrm{g}^{-1}\right)$ e L. buchneri-BUCH (3.64 $\left.\mathrm{x} 10^{5} \mathrm{cfu} \mathrm{g}^{-1}\right)$. Sugar cane (12 month of vegetative growth) was ensiled in $20 \mathrm{~L}$ plastic buckets provided with valves for gases release and a device for effluent collection. Laboratory silos were kept under ambient temperature. Total DM, gases and effluent losses were evaluated through gravimetry. Comparing treated silages with control after 94 days from sealing indicated: urea, BENZ, SORB and BUCH resulted in silages with less etanol, however $\mathrm{LAB}$ resulted in higher ethanol concentration $(\mathrm{P}<0.05)$; urea and SORB treatments decreased total DM losses $(\mathrm{P}<0.05)$; IVDDM was higher for urea and lower for $\mathrm{LAB}$ treated silages $(\mathrm{P}<0.05)$; water soluble carbohydrates $(\mathrm{CHOs})$ content 
was higher in BENZ treated silage $(\mathrm{P}<0.05)$. Regression slopes performed through 144 days after ensiling indicated: ethanol yield was maximum between 60 and 90 days; gases losses were extended up to 90 days and was inhibited in urea treated silage; BUCH inoculated silages showed a trend for depleted CHOS pool; treatments with urea and SORB resulted in silages with increased total DM and effluent losses; IVDDM decreased linearly across time in chemically treated, probably due to the increased effluent yield. BUCH and BENZ improved silages aerobic stability over control (78 and $72 \mathrm{~h}$ vs $48 \mathrm{~h})$.

\subsection{Introdução}

A ensilagem da cana-de-açúcar têm sido realizada como forma de se evitar problemas de manejo dos canaviais, quando o volume empregado desta forrageira dificulta o corte diário, ou na ocorrência de incêndios e geadas. No entanto, silagens de cana-de-açúcar produzidas sem a utilização de aditivos, que controlem a produção de etanol, resultam em forragens de baixa qualidade, não permitindo desempenho adequado dos animais com elas alimentados, apresentando perdas excessivas de matéria seca e de elementos nutritivo durante sua conservação (Alli et al., 1982; Kung, Jr. e Stanley, 1982; Coan et al., 2002).

A aplicação de uréia pode melhorar a qualidade das silagens de cana-de-açúcar, diminuindo a população de leveduras e mofos, reduzindo a produção de etanol, as perdas de MS e de carboidratos solúveis, propiciando melhor composição bromatológica nas silagens, em comparação a silagens sem aditivos (Alli et al., 1983). Entretanto, nos poucos trabalhos recentes onde se avaliou o efeito da uréia na ensilagem da cana-deaçúcar, no Brasil, não se observou redução no teor de etanol, embora tenha havido menores perdas totais de MS (capítulo 4 ) e melhoria de alguns parâmetros nutricionais das silagens tratadas (Lima et al., 2002), com variação entre diferentes doses do aditivo.

Os ácidos sórbico e benzóico têm demonstrado efeito inibidor sobre leveduras e mofos, melhorando a conservação e a estabilidade aeróbica de silagens (Ohyama et al., 1975; Britt et al., 1975; Lättemäe e Lingvall, 1996). Em etapa anterior deste projeto de 
pesquisa, estes produtos foram avaliados em diversas doses como aditivos na ensilagem da cana-de-açúcar (capítulo 4) e, embora não tenha sido detectado efeito sobre a concentração de etanol das silagens, foi constatado que o tratamento com sorbato de potássio $(0,03 \%)$ possibilitou redução significativa na perda total de MS e que o benzoato de sódio $(0,1 \%)$ demonstrou efeito positivo sobre a DVIVMS e a estabilidade aeróbica das silagens.

Inoculantes microbianos contendo as bactérias heterofermentativas L. buchneri, que produzem ácido acético além do ácido lático, têm sido capazes de reduzir a população de leveduras e de aumentar a estabilidade aeróbica de silagens de gramíneas de clima temperado (Ranjit and Kung, Jr., 2000, Taylor et al., 2002). A primeira avaliação do seu uso na ensilagem da cana-de-açúcar (capítulo 4), resultou em redução de aproximadamente $56 \%$ na perda total de MS e redução na produção de etanol (1,95 vs 3,82\% da MS), em relação à silagem não aditivada.

$\mathrm{Na}$ tentativa de melhorar a qualidade das silagens de cana-de-açúcar, alguns pecuaristas têm utilizado inoculantes contendo bactérias homofermentativas produtoras de ácido lático. A intensificação da produção de ácido lático normalmente acarreta redução das perdas de $\mathrm{MS}$ das silagens, promovendo o rápido abaixamento do $\mathrm{pH}$ e estabilização da forragem (McDonald et al., 1991). No entanto, é fato conhecido que apenas o abaixamento do $\mathrm{pH}$ não é suficiente para impedir o desenvolvimento de leveduras e que o ácido lático tem baixo poder fungicida (McDonald et al. 1991), de forma que, o seu emprego na conservação de silagens de cana-de-açúcar mostrou-se prejudicial ao processo de fermentação, triplicando o teor de etanol (12,5 vs 3,82\% MS) e provocando redução na digestibilidade da MS da silagem (41,2 vs 45,4\%) (capítulo 4).

Após a abertura dos silos, a exposição da forragem ao oxigênio é inevitável permitindo o crescimento de microrganismos aeróbicos facultativos que causam a deterioração da silagem, sendo que, também durante o período de estocagem algum oxigênio pode penetrar por difusão, ou por dano físico, através do material usado na cobertura do silos. O processo de deterioração aeróbica é iniciado por leveduras e à medida que ocorre o processo de oxidação dos produtos da fermentação da silagem, o $\mathrm{pH}$ se eleva e outros microrganismos começam a proliferar, em um processo que resulta 
em perdas de componentes nutritivos da silagem, e que pode também comprometer sua qualidade higiênica, devido ao desenvolvimento de microrganismos patogênicos (Driehuis et al, 1999).

O presente experimento tem como objetivo avaliar o efeito da aplicação da uréia, do benzoato de sódio, do sorbato de potássio e de inoculantes microbianos contendo $L$. plantarum e L. buchneri, sobre a dinâmica da fermentação e das perdas de MS durante o processo de conservação de silagens de cana-de-açúcar, estabelecendo as curvas de tendência temporal dos diversos parâmetros, determinando ainda o efeito destes aditivos sobre a estabilidade aeróbica das silagens.

\subsection{Material e Métodos}

A cana-de-açúcar, variedade RB785841, foi colhida madura (aproximadamente 12 meses de arescimento; segundo corte) com colhedora (Mentamit ${ }^{\circledR}$ ) acoplada ao trator, regulada para corte com tamanho de partículas médio entre 5 a $10 \mathrm{~mm}$. A ensilagem foi realizada no dia 19 de julho de 2002 e os minisilos foram mantidos em local coberto, sob temperatura ambiente, no Setor de Ruminantes do Departamento de Zootecnia da ESALQ/USP de Piracicaba, SP. O teor de açúcares da cana-de-açúcar foi avaliado através de refratômetro de campo, e indicou valor médio para o grau brix de 17,4.

\subsubsection{Silos experimentais e produção das silagens}

Como silos experimentais (unidades experimentais) foram utilizados baldes de plástico de 20 litros (minisilos), com tampas próprias à vedação adaptadas com válvulas do tipo Bunsen, para avaliação das perdas gasosas durante a ensilagem. No fundo de cada balde foram colocados dois quilos de areia seca, separados da silagem por tela fina de plástico e duas camadas de tecido fino de algodão, com vistas à avaliação quantitativa de efluentes. 
A ensilagem foi realizada, compactando-se com os pés camadas de 5 a $10 \mathrm{~cm}$ de espessura da cana-de-açúcar picada, buscando-se atingir a maior quantidade possível de forragem em cada balde, para uniformização da densidade das silagens entre os minisilos. Aproximadamente $9 \mathrm{~kg}$ de forragem foram ensilados em cada balde, resultando em densidade aproximada de $500 \mathrm{~kg} / \mathrm{m}^{3}$ na silagem, levando-se em conta o volume do balde que foi preenchido com areia.

Após o enchimento, os silos experimentais foram fechados com as tampas apropriadas e pesados, após o que as tampas foram vedadas com fita plástica adesiva.

\subsubsection{Tratamentos e aplicação dos aditivos}

Os aditivos químicos testados foram a uréia, na forma de fertilizante granulado contendo $45 \%$ de $\mathrm{N}$, o benzoato de sódio na forma de granulado solúvel e o sorbato de potássio em pó solúvel. Os inoculantes microbianos utilizados foram: Ecosyl (ECOSYL Products Limited - número de registro na Inglaterra: 3155665), contendo cepa da bactéria homolática Lactobacillus plantarum e um inoculante não comercial contendo bactérias heteroláticas Lactobacillus buchneri (cepa NCIMB $40788^{\circledR}$ ), fornecido pela Biotal Ltd (Cardiff, UK).

Os aditivos foram misturados uniformemente à cana-de-açúcar, em soluções aquosas e por meio de pulverizador costal, momentos antes da ensilagem, para obtenção das seguintes concentrações (em relação ao peso da forragem fresca): uréia 0,5\%; benzoato de sódio $0,1 \%$ e sorbato de potássio $0,03 \%$. Os dois inoculantes microbianos foram aplicados de acordo com a recomendação dos fabricantes visando-se a adição de 1 x $10^{6} \mathrm{ufc/t}$ de forragem, para o L. plantarum e 3,64 x $10^{5} \mathrm{ufc/t}$ para o L. buchneri. A uréia foi aplicada utilizando-se $30 \mathrm{~L}$ de solução/t de forragem. Para a aplicação dos aditivos BENZ e SORB utilizou-se $12 \mathrm{~L}$ de solução/t. Os inoculantes microbianos foram aplicados em baixo volume, ou seja, 1,89 L de solução/t de forragem, utilizando-se pulverizadores manuais pequenos com capacidade para $500 \mathrm{ml}$. 


\subsubsection{Avaliação das perdas e amostragem das silagens}

Os minisilos foram pesados, e amostrados, decorridos 2, 10, 31, 62 e 94 e 144 dias da ensilagem. As datas foram estabelecidas para que fosse possível a determinação das curvas de tendência temporal dos parâmetros de fermentação, dos indicadores de perdas de matéria seca e dos componentes indicadores do valor nutritivo das silagens. Os baldes foram pesados também antes da ensilagem, com a tampa e contendo o aparato para colheita de efluentes, para que fosse possível o cálculo do peso líquido da forragem contida em cada silo experimental e, posteriormente, dos efluentes.

Em cada dia de amostragem procedeu-se à retirada das fitas adesivas e pesagem dos minisilos antes da abertura, após o que realizava-se a tomada de amostras de silagem, retirada da forragem dos baldes e pesagem dos mesmos contendo apenas o aparato de colheita de efluentes. Cada amostra de silagem foi composta por duas a três porções retiradas da parte central da massa de forragem contida em cada silo. As amostras destinadas à determinação do $\mathrm{pH}$, dos teores de etanol e carboidratos solúveis em água (CHOs), foram colocadas em sacos de plástico e estocadas em congelador ($\left.5^{\circ} \mathrm{C}\right)$ e as amostras utilizadas para as demais análises bromatológicas foram colocadas em sacos de papel e secas em estufa com ventilação forçada a $60^{\circ} \mathrm{C}$ por $48 \mathrm{~h}$.

A perda de matéria seca na forma de gases foi calculada pela diferença entre o peso bruto inicial e final dos minisilos e a quantidade de efluentes pela diferença entre o peso inicial e final dos baldes contendo apenas a areia, a tela plástica e o tecido de algodão. A perda total de matéria seca das silagens, foi calculada pela diferença entre o peso da matéria seca da forragem inicialmente colocada em cada minisilo e o peso da matéria seca da silagem no dia da abertura.

\subsubsection{Análises químico-bromatológicas}

As amostras secas de silagem foram moídas contra peneira de malha de $1 \mathrm{~mm}$ e posteriormente analisadas pelo método da espectroscopia de reflectância de infravermelho proximal (NIRS) (Berzaghi et al., 1997; Cozzolino et al., 2001) 
utilizando-se um espectrofotômetro modelo NIRS $5000^{\circledR}$ (NIRSystems, Silver Spring, MD, USA). A análise utilizou comprimentos de onda entre 700 e $2100 \mathrm{~nm}$ e os espectros das amostras "escaneadas" foram armazenados em curvas log (1/R) em intervalos de 2nm. O método de seleção existente no "software" do equipamento identificou as amostras distantes mais de $3 \mathrm{H}$ (distância padronizada de Mahalanobis) da média, "outliers", que foram excluídas. Adotando-se uma distância mínima de 0,6 H entre amostras (Shenk \& Westerhaus, 1991), foram selecionadas as que deveriam ser analisadas pelos métodos da bromatologia convencional. De posse dos resultados destas análises, o programa do equipamento NIRS foi capaz de inferir a composição química e bromatológica das demais amostras.

As análises das amostras selecionadas pelo método NIRS foram realizadas como segue:

- matéria seca em estufa a $105^{\circ} \mathrm{C}$ por 8 horas.

- a matéria mineral (cinzas) foi obtida pela incineração das amostras em mufla a $600{ }^{\circ} \mathrm{C}$ por 3 horas.

- os teores de fibra em detergente neutro (FDN) e a digestibilidade verdadeira "in vitro" matéria seca (DVIVMS) foram determinados através do método ANKON ${ }^{\circledR}$ Fiber Analyser (ANKON Technology Corporation, Fairport, NY).

- os teores de fibra em detergente ácido (FDA) e de lignina (LIG) foram avaliados segundo os métodos propostos por Van Soest et al. (1985) e a proteína bruta (PB) segundo AOAC (1990).

- o teor de PB para o tratamento com uréia foi determinado pelo método macro Kjeldahl (AOAC, 1990), em amostras úmidas de silagem que haviam sido mantidas congeladas $\left(-5^{\circ} \mathrm{C}\right)$.

Os teores de etanol e de CHOs foram determinados em extratos aquosos das amostras de silagem, obtidos segundo método descrito por Kung, Jr. (1996). Para isto, $25 \mathrm{~g}$ de amostra úmida foram processados com $225 \mathrm{~mL}$ de água destilada, em liquidificador, durante um minuto. Em seguida, o material foi filtrado em papel de filtro Whatman ${ }^{\circledR} 54$, acidificado com $\mathrm{H}_{2} \mathrm{SO}_{4}$ a $50 \%$ e centrifugado, sendo o extrato líquido armazenado em congelador $\left(-5^{\circ} \mathrm{C}\right)$ até o momento das análises. $\mathrm{O} \mathrm{pH}$ foi determinado 
nos extratos, antes da filtragem, através de um potenciômetro digital da marca Digimed $^{\circledR}$, modelo DM 20. As análises do teor de etanol foram realizadas nos laboratórios do Setor de Açúcar e Álcool do Departamento de Agroindústria Alimentos e Nutrição da ESALQ/USP de Piracicaba, por meio de cromatógrafo a gases com detector de ionização de chama, marca Gregório e Cioli ${ }^{\circledR}$, modelo CG-37D. As determinações dos teores de CHOs foram realizadas pelo método colorimétrico de Dubois et al. (1956), diluindo-se os extratos aquosos das amostras de silagens, na proporção de $1 \mathrm{~mL}$ de extrato para $20 \mathrm{~mL}$ de água destilada.

\subsubsection{Caracterização da microflora epífita}

Amostras foram tomadas, da cana-de-açúcar antes da ensilagem e das silagens nos dias de abertura dos silos experimentais, para identificação e contagem das leveduras presentes na forragem. As amostras (aproximadamente $25 \mathrm{~g}$ ) foram colocadas em sacos de plástico e mantidas resfriadas em caixas de poliestireno (isopor) contendo bolsas de gelo, sendo encaminhadas no dia seguinte para análise no Laboratório de Micotoxinas do Departamento de Microbiologia do Instituto de Ciências Biomédicas da USP em São Paulo, SP.

\subsubsection{Avaliação da estabilidade aeróbica}

A estabilidade aeróbica das silagens (expressa em horas) foi avaliada através do controle da temperatura das silagens expostas ao ar, segundo método adaptado de Kung, Jr. (2000). Por ocasião da abertura dos minisilos realizada aos 90 dias de ensilagem, amostras em triplicata, de aproximadamente $3,5 \mathrm{~kg}$ das silagens de cada tratamento, foram colocadas sem compactação em baldes de plástico sem tampa, mantidos em ambiente coberto. As temperaturas foram tomadas 2 vezes ao dia $(8: 30$ e 17:30 h) por meio de termômetros posicionados no centro geométrico da massa de forragem de cada balde. Consideroutse o início da deterioração quando a temperatura das silagens atingiu $2^{\circ} \mathrm{C}$ acima da temperatura ambiente, que apresentou média de $24,7^{\circ} \mathrm{C}$ e variação entre 
22 e $28^{\circ} \mathrm{C}$, tendo sido medida com um termômetro localizado próximo aos baldes. Também foi considerado na avaliação da estabilidade aeróbica, o acúmulo de cinco e dez dias, da diferença média diária entre a temperatura das silagens expostas ao ar e a temperatura ambiente (ADITE-5 e ADITE-10; expressos em ${ }^{\circ} \mathrm{C}$ ).

\subsubsection{Análise estatística}

$\mathrm{Na}$ avaliação da dinâmica da fermentação das silagens, o delineamento experimental utilizado foi o inteiramente casualizado, com três repetições, em esquema de parcelas subdivididas (split-pot), sendo os fatores das parcelas os tratamentos e o fator tempo atribuído à subparcela (2, 10, 31, 62, 94 e 144 dias). O teor de MS inicial da cana-de-açúcar de cada tratamento foi testado como covariável, e diante da ausência de efeito foi removido do modelo original. O modelo proposto foi analisado pelo PROC GLM do SAS (SAS, 1988) e as comparações das médias foram realizadas utilizando-se o Método dos Quadrados Mínimos (LSMEANS). Foram declaradas significativas as diferenças entre médias a partir de $\mathrm{P}<0,01$ ). Aplicourse o teste $\mathrm{F}$ para contraste, a partir do desdobramento dos graus de liberdade. O objetivo foi comparar os parâmetros das silagens nos períodos de ensilagem.

$\mathrm{Na}$ avaliação da estabilidade aeróbica das silagens, empregourse o delineamento experimental inteiramente casualizado, com seis tratamentos e três repetições. O modelo proposto foi analisado pelo PROC GLM do SAS (SAS, 1988) e as comparações das médias foram realizadas utilizando-se o Método dos Quadrados Mínimos (LSMEANS). Foram declaradas significativas as diferenças entre médias a partir de $\mathrm{P}<0,05$. Aplicout se o teste F para contraste, a partir do desdobramento dos graus de liberdade.

\subsection{Resultados e Discussão}

A composição da cana-de-açúcar (Tabela 7) indicou teor de MS médio, teores dos componentes da fibra elevados e DVIVMS baixa, em relação aos valores encontrados em avaliações recentes, de variedades industriais, realizadas por Andrade et 
al.(2002) e Rodrigues et al. (2001). Esses autores relatam teores variando de 37 a $24 \%$ para MS; 56 a 36\% para FDN; 36 a 21\% para FDA; 7 a 3\% para lignina e 69 a 58\% para DVIVMS, em "canas plantas" colhidas aos 12 meses de idade. O teor inicial de carboidratos solúveis (CHOs) foi determinado apenas na amostra da cana-de-açúcar do tratamento controle, podendo ser considerado elevado, em relação valores relatados em trabalhos de pesquisa realizados no Brasil, que situam-se ao redor de 18\% (Coan et al., 2002; Bernardes et al., 2002). Trabalhos realizados no exterior indicam valores mais altos, como 52\% de CHOs na MS para cana-de-açúcar colhida aos 7,5 meses de crescimento (Alli \& Baker, 1982) e 34\% de CHOs para cana colhida aos 16,5 meses (Alli et al., 1983). No entanto, o teor de CHOs foi semelhante ao encontrado em avaliação anterior deste projeto de pesquisa (capítulo 3), para cana-de-açúcar colhida aproximadamente no mesmo estádio de desenvolvimento.

Tabela 7. Composição da cana-de-açúcar fresca, pura e após a adição dos aditivos

\begin{tabular}{|c|c|c|c|c|c|c|c|c|c|c|}
\hline \multirow[t]{2}{*}{ Tratamento } & \multirow[t]{2}{*}{$\mathrm{pH}$} & \multirow{2}{*}{$\begin{array}{l}\text { MS } \\
(\%)\end{array}$} & CHOs. & Etanol & $\mathrm{PB}$ & FDN & FDA & Lignina & Cinzas & \multirow{2}{*}{$\begin{array}{c}\text { DVIVMS } \\
(\%)\end{array}$} \\
\hline & & & & & & $(\% \mathrm{MS})$ & & & & \\
\hline Controle & 5,95 & 29,3 & 23,3 & 0,21 & 3,43 & 55,5 & 37,4 & 6,80 & 8,10 & 51,3 \\
\hline Uréia $0,5 \%$ & 5,83 & 29,9 & nd & nd & 3,13 & 54,5 & 36,6 & 6,69 & 7,93 & 52,0 \\
\hline Benzoato $0,1 \%$ & 5,89 & 29,7 & nd & nd & 3,28 & 53,6 & 36,3 & 6,66 & 8,55 & 51,8 \\
\hline Sorbato $0,03 \%$ & 5,82 & 31,3 & nd & nd & 3,42 & 57,5 & 38,5 & 6,88 & 8,13 & 49,6 \\
\hline L. buchneri & 5,78 & 31,3 & nd & nd & 3,32 & 55,1 & 36,8 & 6,75 & 7,56 & 51,9 \\
\hline L. plantarum & 5,81 & 31,5 & nd & nd & 3,34 & 54,1 & 36,3 & 6,64 & 7,94 & 52,3 \\
\hline Média & 5,85 & 30,5 & 23,3 & 0,21 & 3,32 & 55,1 & 37,0 & 6,74 & 8,03 & 51,5 \\
\hline
\end{tabular}

$\mathrm{PB}=$ proteína bruta; $\mathrm{FDN}$ = fibra em detergente neutro; FDA = fibra em detergente ácido; DVIVMS = digestibilidade verdadeira in vitro da MS; MS = matéria seca; $\mathrm{MV}=$ massa verde; ufc = unidades formadoras de colônia.

L. buchneri $=>3,64 \times 10^{5} \mathrm{ufc/g} \mathrm{MV} ;$ L. plantarum $=>1 \times 10^{6} \mathrm{ufc} / \mathrm{g} \mathrm{MV}$.

\subsubsection{Efeito dos tratamentos e do período de ensilagem sobre a composição e as perdas de MS das silagens}

O teor de etanol da silagem do tratamento controle (Tabela 8) pode ser considerado baixo, sendo que os valores encontrados na literatura situam-se entre 5,5\% e 15,5\% de etanol na MS (Preston et al., 1976; Kung, Jr. and Stanley, 1982) para 
silagens de cana-de-açúcar colhida aos 12 meses de crescimento e ensilada sem aditivos. As perdas por gases situaram-se dentro dos níveis normais, considerando-se o tempo de ensilagem, mas a perda de CHOs (61\%) e a perda total de MS foram relativamente pequenas (Tabela 8), tendo em vista que foram relatadas perdas de 93 a $96 \%$ na concentração de CHOs, em silagens com aproximadamente 9\% de etanol na MS (Alli \& Baker, 1982; Alli et al.,1983) e 29\% de perda total da MS em silagem com 13,7\% de etanol na MS (Kung, Jr. \& Stanley,1982). Os valores podem ser considerados semelhantes aos encontrado anteriormente por Pedroso (2003) para silagem de cana-deaçúcar da mesma variedade, ensilada aproximadamente no mesmo estádio de desenvolvimento. Deve-se ressaltar que, o fato das perdas de MS por gases e total da silagem sem aditivos terem sido relativamente reduzidas, pode ter dificultado a detecção de diferenças significativas quando estas foram comparadas aos outros tratamentos.

Os tratamentos com uréia, benzoato, sorbato e L. buchneri levaram à redução significativa $(\mathrm{P}<0,05)$ na concentração de etanol das silagens, em relação à silagem controle (Tabela 8), ao contrário do obtido anteriormente por Pedroso (2003) que não detectaram efeito destes aditivos sobre a produção desse álcool, em relação à silagem não aditivada.

Dentre todos aditivos testados, a inoculação com L. buchneri resultou em redução de aproximadamente $50 \%$ no teor de etanol e menor contagem de leveduras em relação ao controle $(\mathrm{P}<0,05)$ (Tabela 8$)$, confirmando as informações de que inoculantes contendo estas bactérias são capazes de reduzir a população das leveduras pelo aumento da concentração de ácido acético nas silagens (Driehuis et al., 1999; Ranjit et al. 2002). No entanto, a perda de MS na forma de gases, a perda total de MS, a concentração de CHOs e a DVIVMS, para este tratamento, foram semelhantes às do tratamento controle $(\mathrm{P}>0,05)$. Em etapa anterior deste projeto onde se avaliou a dinâmica da produção de álcool e das perdas durante a ensilagem, da cana-de-açúcar sem aditivos (capítulo 4), foi constatada correlação positiva entre o teor de etanol e as perdas de MS total e na forma de gases $(r=0,893$ e 0,903, respectivamente) e correlação negativa entre o teor de etanol e o teor de CHOs residuais na silagem $(r=-0,863)$, evidenciando o fato de que a produção de etanol pelas leveduras é acompanhada pela perda acentuada de MS dos 
substratos, na forma de $\mathrm{CO}_{2}$ e $\mathrm{H}_{2} \mathrm{O}$ (McDonald et al., 1991). A inoculação com $L$. buchneri no entanto, apesar de ter causado a redução na produção de etanol, não foi acompanhada por uma redução nas perdas gasosas e no consumo de CHOs da silagem, podendo-se inferir que, a redução na população de leveduras e no teor de álcool observada com este tratamento (Tabela 8) ocorreu às expensas do consumo de CHOs e da perda de MS da forragem, durante a produção de ácido acético pelas bactérias do inoculante, já que a via de produção deste ácido pelas bactérias heterofermentativas também gera perda de MS (4,8\% do substrato) (McDonald et al., 1991). Deve ser observado que, na maioria dos trabalhos onde se avaliou o efeito da inoculação de silagens com L. buchneri, não foram detectadas maiores perdas de MS devido à ação do inoculante, embora tenha havido maior concentração de ácido acético nas silagens (Taylor \& Kung, Jr., 2002; Ranjit et al., 2002). No entanto, não existem informações sobre o efeito deste inoculante sobre o padrão de fermentação de silagens de cana-deaçúcar, que auxiliem na elucidação de seu efeito.

Tabela 8. Composição bromatológica, perdas e população de leveduras em silagens de cana-de-açúcar, sob o efeito de aditivos químicos e microbianos, aos 94 dias após a ensilagem

\begin{tabular}{|c|c|c|c|c|c|c|c|c|}
\hline \multirow[t]{2}{*}{ Tratamento } & \multirow[t]{2}{*}{$\mathrm{pH}$} & Etanol & CHOs. & $\begin{array}{c}\text { Perda de } \\
\text { Gases }\end{array}$ & DVIVMS & $\begin{array}{c}\text { Perda total } \\
\text { de MS }\end{array}$ & \multirow{2}{*}{$\begin{array}{l}\text { Efluente } \\
\mathrm{kg} / \mathrm{t} \mathrm{MV}\end{array}$} & \multirow{2}{*}{$\begin{array}{l}\text { Leveduras } \\
\text { Log ufc/g MV }\end{array}$} \\
\hline & & \multicolumn{3}{|c|}{$\% \mathrm{MS}$} & \multicolumn{2}{|r|}{$\%$} & & \\
\hline Controle & $3,65^{c}$ & $4,05^{b}$ & $9,13^{b c}$ & $6,14^{b}$ & $46,6^{b}$ & $6,82^{b}$ & $6,98^{c}$ & $6,49^{A}$ \\
\hline Uréia $0,5 \%$ & $3,81^{\mathrm{a}}$ & $2,48^{\mathrm{cd}}$ & $9,21^{b c}$ & $5,47^{b}$ & $48,6^{\mathrm{a}}$ & $12,6^{\mathrm{a}}$ & $23,6^{\mathrm{a}}$ & $6,05^{A B}$ \\
\hline Benzoato $0,1 \%$ & $3,70^{\mathrm{b}}$ & $3,21^{\mathrm{c}}$ & $13,4^{\mathrm{a}}$ & $5,81^{\mathrm{b}}$ & $47,8^{a b}$ & $10,4^{a b}$ & $12,2^{b}$ & $5,66^{B}$ \\
\hline Sorbato $0,03 \%$ & $3,64^{\mathrm{c}}$ & $2,93^{\mathrm{c}}$ & $10,6^{b}$ & $6,14^{b}$ & $46,4^{b}$ & $11,5^{\mathrm{a}}$ & $11,1^{b c}$ & $6,05^{A B}$ \\
\hline L. buchneri & $3,65^{\mathrm{c}}$ & $1,90^{\mathrm{d}}$ & $5,69^{\mathrm{c}}$ & $6,73^{a b}$ & $46,0^{b}$ & $5,19^{b}$ & $2,30^{\mathrm{cd}}$ & $5,65^{B}$ \\
\hline L. plantarum & $3,57^{\mathrm{d}}$ & $4,90^{\mathrm{a}}$ & $7,92^{\mathrm{c}}$ & $8,04^{\mathrm{a}}$ & $43,9^{\mathrm{c}}$ & $7,70^{\mathrm{b}}$ & $0,59^{d}$ & $6,25^{A}$ \\
\hline Média & 3,67 & 3,25 & 9,32 & 6,39 & 46,6 & 9,04 & 9,47 & --- \\
\hline EPM & $\underset{* *}{0,02}$ & 0,22 & 0,79 & 0,54 & $\begin{array}{c}0,43 \\
* *\end{array}$ & $\begin{array}{c}1,19 \\
* *\end{array}$ & $\begin{array}{l}1,56 \\
* *\end{array}$ & -- \\
\hline Efeito Trat. & & & & 0,0653 & & & & --- \\
\hline
\end{tabular}

Deve-se notar que, na avaliação anterior realizada por Pedroso (2003), a aplicação do inoculante contendo L. buchneri resultou em maior produção de efluente 
em relação à silagem controle, mesmo tendo apresentado maior teor de MS, fato que não se repetiu nesta avaliação.

O efeitos observados com o tratamento com uréia (Tabela 8), confirmam a capacidade deste produto em inibir o desenvolvimento de leveduras diminuindo a concentração de etanol nas silagens (Alli et al., 1983), no entanto, observa-se que não houve diminuição nas perdas de gases e de CHOs. Nas Figuras 8 e 9 pode-se constatar que, enquanto as silagens dos outros tratamentos atingiram $\mathrm{pH}$ igual ou inferior a 4 , aos dez dias de fermentação, aproximadamente, a silagem a silagem tratada com $0,5 \%$ de uréia deve ter atingido estes níveis por volta de 20 dias após a ensilagem. Desta forma, pode-se supor que enterobactérias e clostridia tiveram seu período de desenvolvimento prolongado, devido ao retardamento da queda do $\mathrm{pH}$ da silagem provocado pelo poder tamponante da uréia, levando às perdas mencionadas, pela maior produção de ácido acético, ácido butírico e outros produtos de fermentação (McDonald et al., 1991, Rotz \& Muck, 1994).

Tabela 9. Composição bromatológica das silagens de cana-de-açúcar, sob o efeito de aditivos químicos e microbianos , aos 94 dias após a ensilagem

\begin{tabular}{|c|c|c|c|c|c|c|}
\hline \multirow[t]{2}{*}{ Tratamento $^{1}$} & \multirow{2}{*}{$\begin{array}{c}\mathrm{MS} \\
\%\end{array}$} & PB & FDN & FDA & Lignina & cinzas \\
\hline & & \multicolumn{5}{|c|}{$\% \mathrm{MS}$} \\
\hline Controle & $28,0^{b c}$ & $3,37^{b}$ & $59,5^{c}$ & $42,3^{b c}$ & $7,76^{b}$ & $8,95^{a}$ \\
\hline Uréia $0,5 \%$ & $27,3^{\mathrm{c}}$ & $7,42^{a}$ & $56,0^{d}$ & $40,2^{d}$ & $7,51^{\mathrm{b}}$ & $8,91^{\mathrm{a}}$ \\
\hline Benzoato $0,1 \%$ & $27,5^{\mathrm{c}}$ & $2,94^{\mathrm{b}}$ & $59,0^{\mathrm{c}}$ & $42,6^{b}$ & $7,66^{\mathrm{b}}$ & $8,85^{\mathrm{a}}$ \\
\hline Sorbato $0,03 \%$ & $28,5^{b}$ & $3,16^{b}$ & $60,2^{c}$ & $42,6^{b}$ & $7,77^{\mathrm{b}}$ & $8,73^{a}$ \\
\hline L. buchneri & $30,4^{a}$ & $3,02^{b}$ & $62,0^{b}$ & $41,7^{\mathrm{c}}$ & $7,73^{\mathrm{b}}$ & $7,74^{\mathrm{b}}$ \\
\hline L. plantarum & $29,8^{a}$ & $3,43^{b}$ & $64,7^{\mathrm{a}}$ & $45,2^{\mathrm{a}}$ & $8,38^{a}$ & $7,80^{\mathrm{b}}$ \\
\hline Média & 28,6 & 3,89 & 60,2 & 42,4 & 7,80 & 8,50 \\
\hline$E P M$ & 0,34 & 0,19 & 0,42 & 0,28 & 0,11 & 0,20 \\
\hline Efeito Trat. & $* *$ & $* *$ & $* *$ & $* *$ & $* *$ & $* *$ \\
\hline
\end{tabular}

T\% da massa verde; ** $\mathrm{P}<0,01$; Letras diferentes na mesma coluna indicam diferença significativa $\mathrm{P}<0,05$.

$\mathrm{PB}=$ proteína bruta; FDN = fibra em detergente neutro; FDA = fibra em detergente ácido; $\mathrm{MS}=$ matéria seca; $\mathrm{MV}=$ massa verde; ufc $=$ unidades formadoras de colônia.

L. buchneri $=>3,64 \times 10^{5} \mathrm{ufc/g} \mathrm{MV;} \mathrm{L.} \mathrm{plantarum}=>1 \times 10^{6} \mathrm{ufc} / \mathrm{g} \mathrm{MV}$.

A adição de uréia também resultou em elevação da DVIVMS em relação à silagem controle $(\mathrm{P}<0,05)$, apesar da maior perda total de MS (Tabela 8). Tal fato 
contraria os índices de correlação obtidos anteriormente (capítulo 4) que mostraram relação negativa $(r=-0,988)$ entre estes parâmetros, indicando que o aumento da perda de MS durante a ensilagem resulta em forragem com menor digestibilidade. Portanto, os resultados obtidos neste experimento podem ter sido devido ao acréscimo no teor de $\mathrm{PB}$ na MS da silagem (Tabela 9), em decorrência do nitrogênio acrescentado através do aditivo.

O tratamento contendo benzoato causou redução na concentração de etanol e na população de leveduras, acompanhada pelo menor consumo de CHOs em relação à silagem controle $(\mathrm{P}<0,05)$ (Tabela 8). Desta forma, apesar de não ter sido detectada diferença na produção de gases e na perda total de MS, houve tendência de aumento na DVIVMS, de forma coerente com a correlação positiva existente entre estes fatores, já mencionada.. Os resultados indicam efeitos semelhantes aos obtidos na avaliação anteriormente realizada (capítulo 4) onde a aplicação do benzoato, apesar de não ter sido capaz de reduzir significativamente a concentração de etanol e as perdas de MS, resultou em silagem de cana-de-açúcar com maior digestibilidade. Lättemäe e Lingvall (1996) também relataram efeito positivo com a aplicação de $0,15 \%$ de benzoato em silagens de capim emurchecido, através de um aditivo contendo também nitrito de sódio e hexamina, obtendo silagens com maior teor de carboidratos solúveis (68 vs 11\% da MS) em comparação à silagem sem aditivo. A adição do sorbato de potássio à silagem, causou redução no teor de etanol, sem que tenha havido efeitos significativos sobre a população de leveduras, as perdas de gases e o teor de CHOs residuais (Tabela 8). Contudo, a perda total de MS foi superior à do tratamento controle $(\mathrm{P}<0,05)$, contrariando resultados anteriores (capítulo 4) onde a perda total de MS com o uso do aditivo, na dose de 0,03\% da MV, foi menor que a da silagem sem aditivos. Os resultados estão de acordo com Weinberg et al. (1989) que também constataram redução no teor do álcool (8,30 vs $15,7 \%$ da MS) para silagem de polpa úmida de laranja tratada com $0,05 \%$ de sorbato de potássio, sem que houvesse redução significativa na contagem de leveduras. Estes pesquisadores comentaram que o efeito do ácido deve ter sido apenas de inibição da atividade destes microrganismos, sem causar sua morte, 
resultando, no entanto, em menor produção de álcool e menores perdas de MS da silagem.

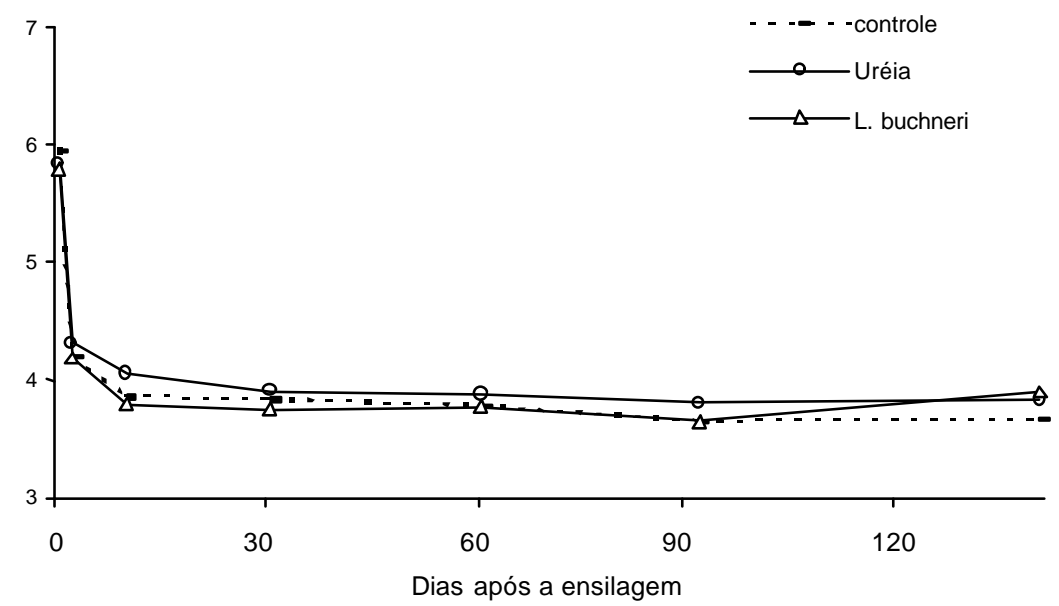

Figura 8 - Evolução temporal do pH das silagens de cana-de-açúcar tratada com uréia e L. buchneri

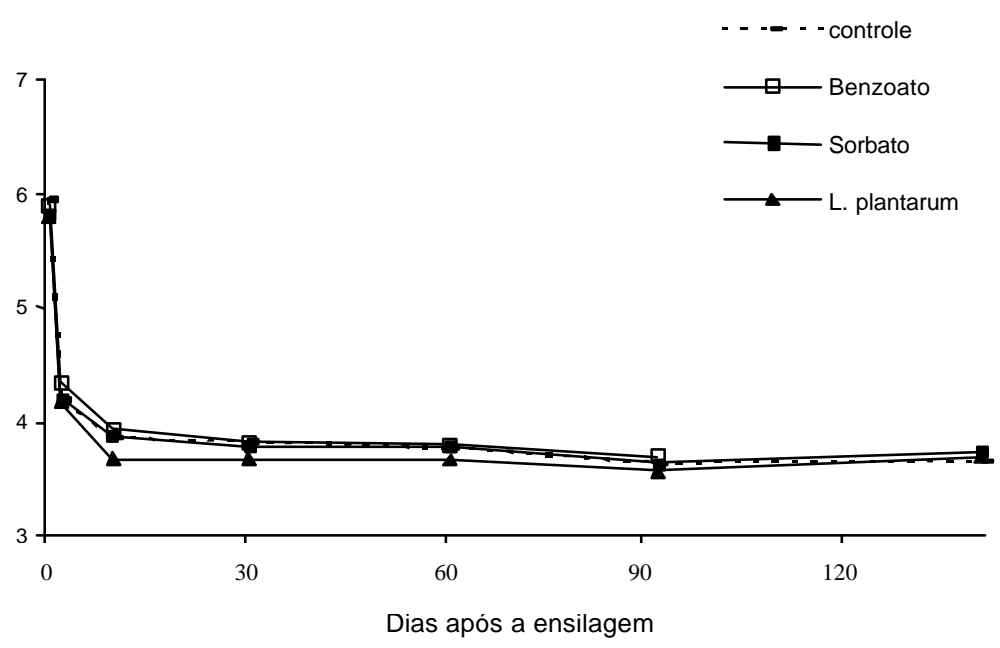

Figura 9 - Evolução temporal do pH das silagens de cana-de-açúcar tratadas com benzoato de sódio, sorbato de potássio e L. plantarum 
A aplicação do inoculante contendo $L$. plantarum resultou em concentração de etanol $21 \%$ maior do que a observada na silagem sem aditivos, efeito que foi acompanhado por maior utilização de CHOs e produção de gases $(\mathrm{P}<0,05)$ (Tabela 8). A silagem inoculada com estas bactérias homoláticas apresentou a menor DVIVMS entre todas avaliadas neste experimento $(\mathrm{P}<0,05)$, equivalente à redução de $16 \%$ em relação à digestibilidade da cana antes da ensilagem. Os dados confirmam os resultados da avaliação anterior do produto (capítulo 4), e reforçam a indicação de que o estímulo à produção de ácido lático é prejudicial no caso da ensilagem da cana-de-açúcar, uma vez que o desenvolvimento das leveduras não é inibido apenas pelo abaixamento do $\mathrm{pH}$ das silagens (McDonald et al., 1991) e o ácido lático apresenta menos da metade do poder fungicida do ácido acético (Moon, 1983). Os resultados sugerem que a adição das bactérias homoláticas causou a diminuição mais rápida do $\mathrm{pH}$, a níveis menores do que 4 (Figura 9), levando à rápida inibição do desenvolvimento das enterobactérias e outras bactérias heterofermentativas, causando redução na concentração de ácido acético na silagem, favorecendo assim o desenvolvimento das leveduras e a produção de álcool.

As silagens de todos os tratamentos apresentaram maiores concentrações dos componentes da fibra e redução no teor de MS em relação aos valores das canas-deaçúcar correspondentes, antes da ensilagem (Tabelas 7 e 9). Os componentes da fibra tornaram-se mais concentrados na MS das silagens devido à perda de CHOs na forma de gases durante a fermentação, o que resulta também na produção de água, diminuindo como conseqüência o teor de MS da forragem $\mathrm{O}$ valor da relação entre os teores de FDN e de sacarose tem sido utilizado na avaliação da qualidade nutritiva da cana-deaçúcar (Rodrigues et al. 2001), considerando-se valores menores ou igual a 3 como indicativo de que o teor de FDN não será limitante ao consumo de MS e, consequentemente, de açúcares que fornecem a maior parte da energia digerível para os animais alimentados com esta forragem. Calculando-se os índices da relação FDN/CHOs das canas-de-açúcar dos diversos tratamentos, antes da ensilagem, obtém-se valores entre 2,3 e 2,5 enquanto que, para as silagens com 94 dias o valor médio dessa relação é 7, o que está de acordo com a diminuição geral da DVIVMS observada (Tabela 8). Através destes cálculos obtém-se o índice mais baixo para a silagem do 
tratamento com benzoato $(4,4)$ e o mais alto para a silagem do tratamento com $L$. buchneri (10,9), sem que esta tenha no entanto apresentado a menor DVIVMS, evidenciando que outros fatores podem interferir no valor nutritivo das silagens.

Ao analisar as curvas da tendência temporal das concentrações de etanol, nas silagens dos diversos tratamentos, expressas na Figura 10, identificou-se o efeito de redução na concentração de etanol nas silagens contendo aditivos, com exceção para o tratamento com L. plantarum, sendo os menores teores de álcool observados para os tratamentos com uréia e L. buchneri. Pode-se constatar que a produção do álcool ocorreu de forma lenta, atingindo os pontos de maior concentração entre 60 e 90 dias de ensilagem, aproximadamente, a partir de quando ocorreu tendência de diminuição na concentração do álcool na MS das silagens. Este fato contraria resultados anteriores deste projeto de pesquisa, que indicaram estabilização na concentração de etanol a partir do $15^{\circ}$ dia da ensilagem (capítulo 3), e de outros experimentos onde a produção do etanol ocorreu dos 6 aos 21 dias após o fechamento dos silos (Alli \& Baker, 1982; Alli et al., 1983).

As curvas referentes às perdas de MS na forma de gases (Figura 11) mostram que, apesar da comparação dos dados da abertura aos 90 dias de ensilagem (Tabela 8) não ter indicado diferença para este parâmetro, entre os tratamentos controle, uréia, benzoato e sorbato, houve tendência temporal de menor perda gasosa para tratamento com uréia. De forma geral a tendência das perdas gasosas refletiu a tendência de concentração de etanol das silagens, podendo notar-se no entanto, que as perdas de gases se prolongaram além dos 90 dias de ensilagem. Em etapa anterior deste projeto as perdas gasosas estabilizaram-se aos 45 dias de ensilagem, e outros trabalhos de pesquisa observaram a maior dessas perdas ocorrendo dentro dos primeiros 30 dias de ensilagem (Ashbell et al., 1987; Alli et al., 1983). No entanto, perdas contínuas podem ocorrer, como foi relatado por Lättemäe \& Lingvall (1996) que, em experimento com silagens de capim azevém (L. perenne L.) com teores elevados de MS (34 a 39\%) e concentrações de CHOs variando entre 6,8 a 1,1\%, detectaram perdas de MS pequenas, porém lineares, dos 30 aos 100 dias de amostragem das silagens. 

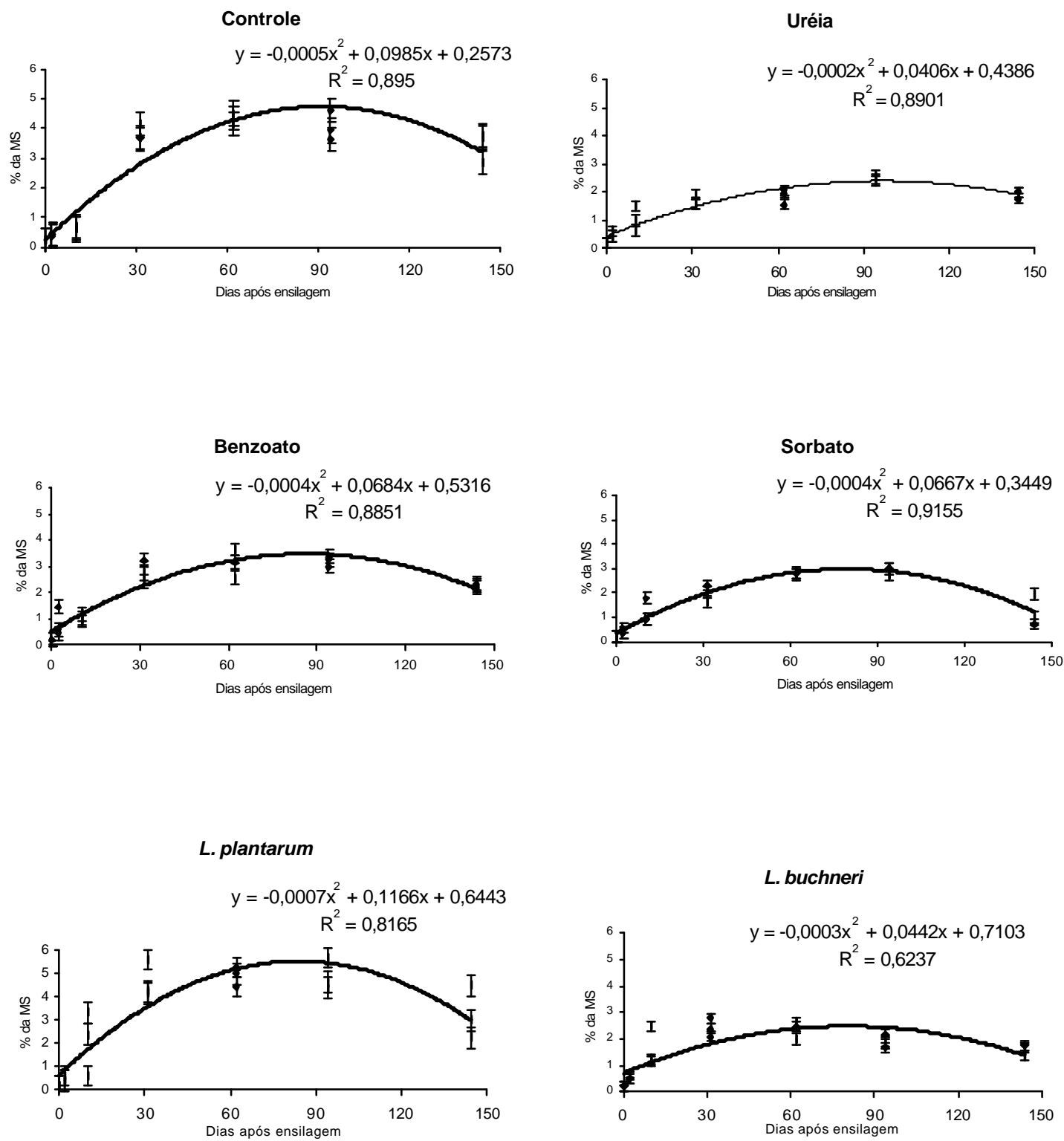

Figura 10 - Tendência temporal da concentração de etanol em silagens de cana-de-açúcar tratadas com aditivos químicos (uréia, benzoato de sódio, sorbato de potássio) e inoculantes microbianos (L. plantarum, L. buchneri) 
Controle

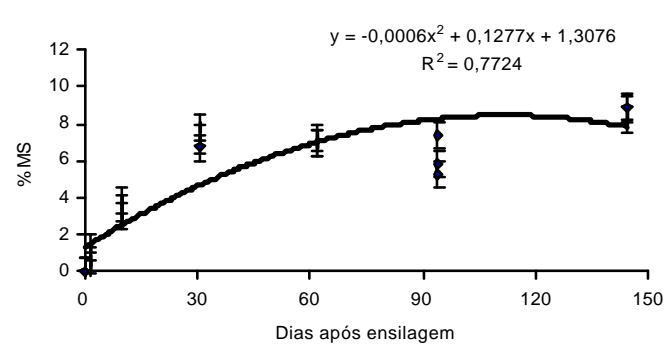

Benzoato

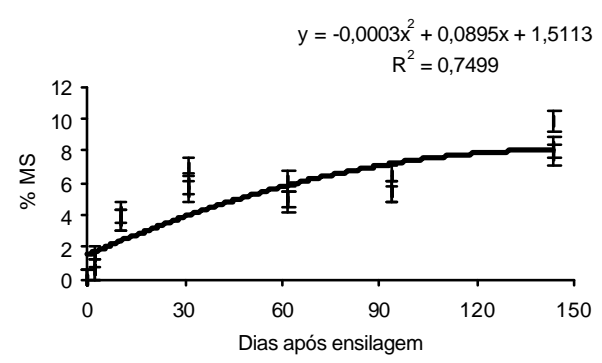

L. plantarum

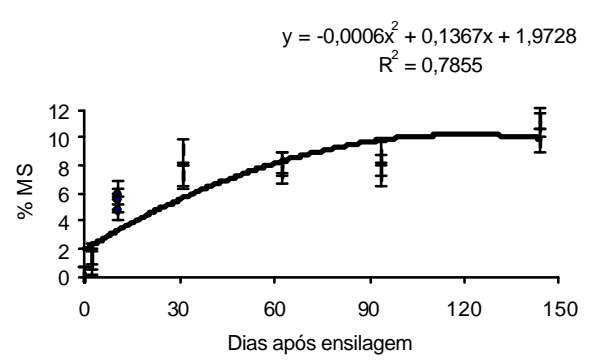

Uréia

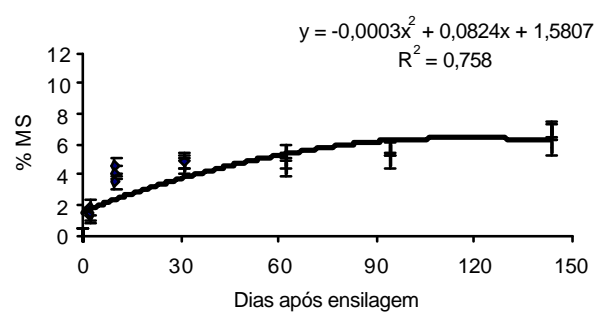

Sorbato

$y=-0,0001 x^{2}+0,0731 x+1,7801$ $R^{2}=0,7419$

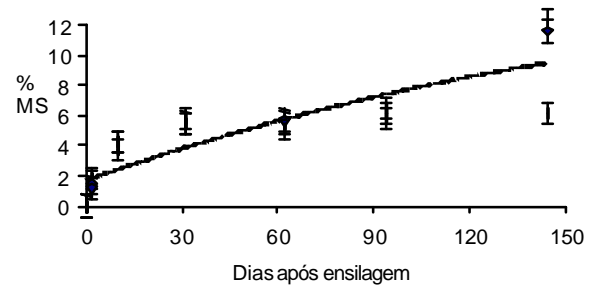

\section{L. buchneri}

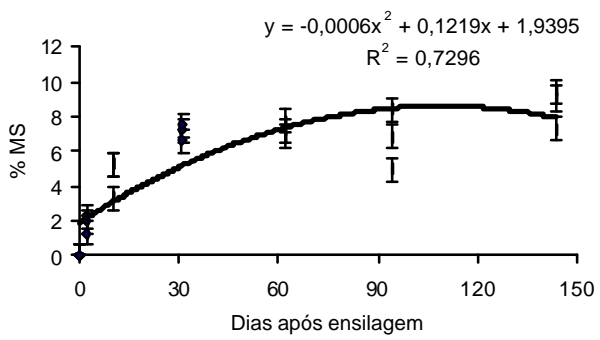

Figura 11 - Tendência temporal da perda de gases (\% da MS) de silagens de cana-de-açúcar tratadas com aditivos químicos (uréia, benzoato de sódio, sorbato de potássio) e inoculantes microbianos (L. plantarum, L. buchneri) 

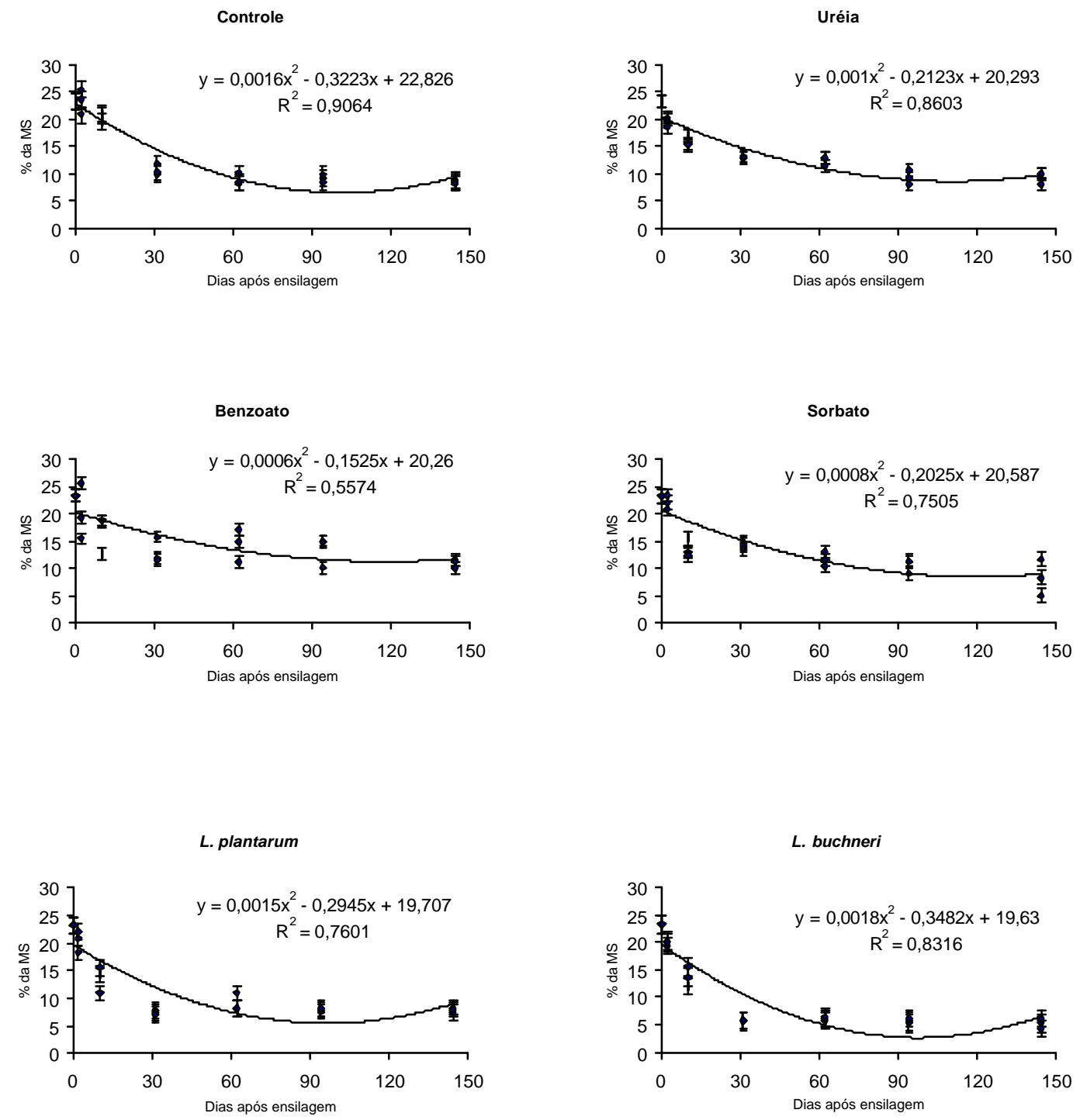

Figura 12 - Tendência temporal da concentração de carboidratos solúveis (CHOs) de silagens de cana-de-açúcar tratadas com aditivos químicos (uréia, benzoato de sódio, sorbato de potássio) e inoculantes microbianos (L. plantarum, $L$. buchneri). 
Controle

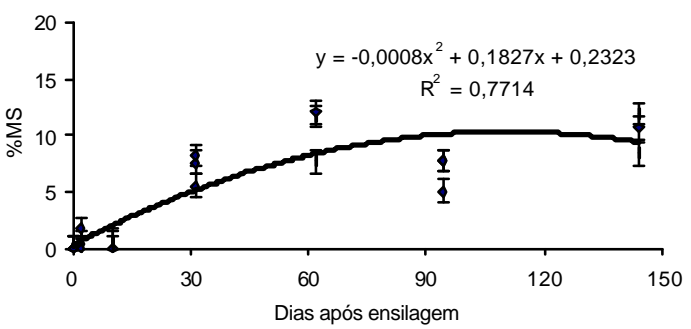

Benzoato

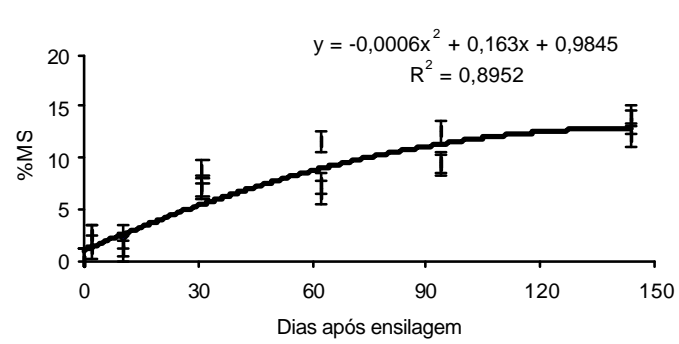

L. plantarum

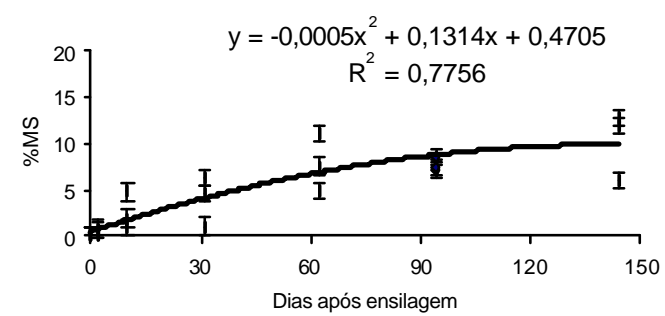

Uréia

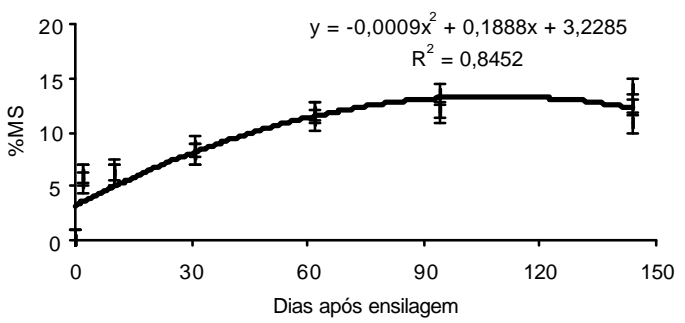

Sorbato

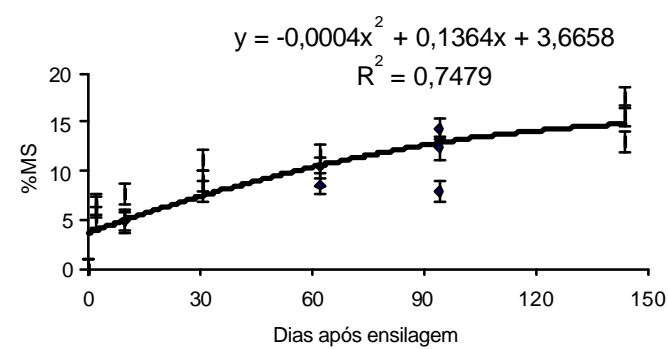

L. buchneri

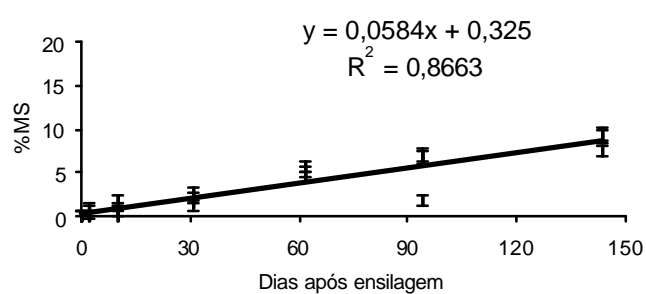

Figura 13 - Tendência temporal da perda total de matéria seca (\% da MS) de silagens de cana-de-açúcar tratadas com aditivos químicos (uréia, benzoato de sódio, sorbato de potássio) e inoculantes microbianos (L. plantarum, L. buchneri) 

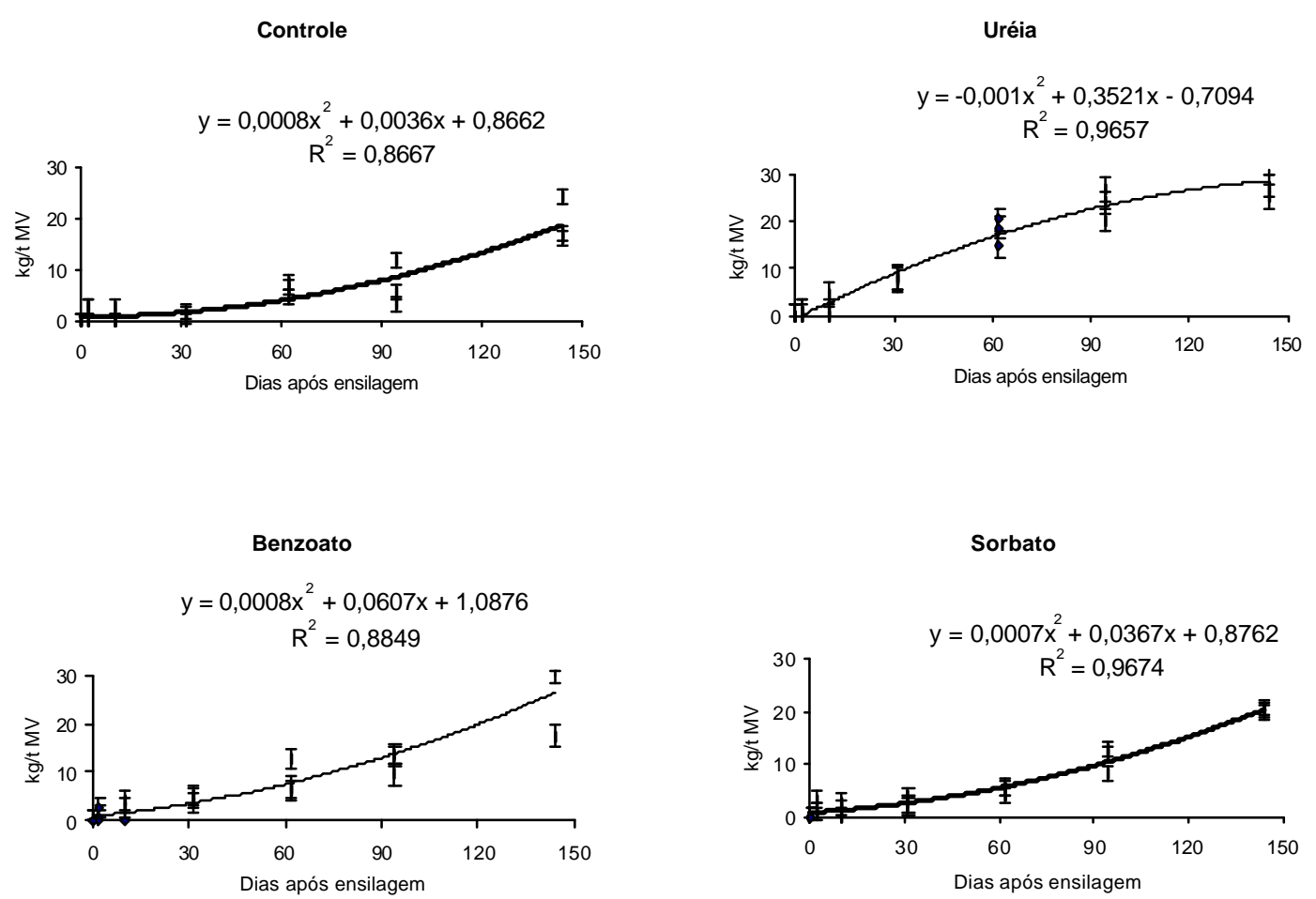

L. plantarum

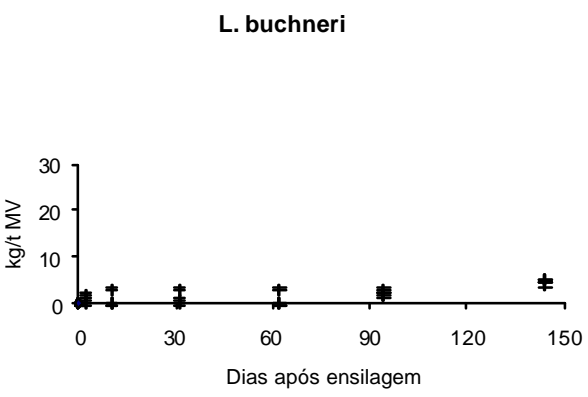

Figura 14 - Tendência temporal da produção de efluentes (kg/t MV) de silagens de cana-deaçúcar tratadas com aditivos químicos (uréia, benzoato de sódio, sorbato de potássio) e inoculantes microbianos (L. plantarum, L. buchneri) 

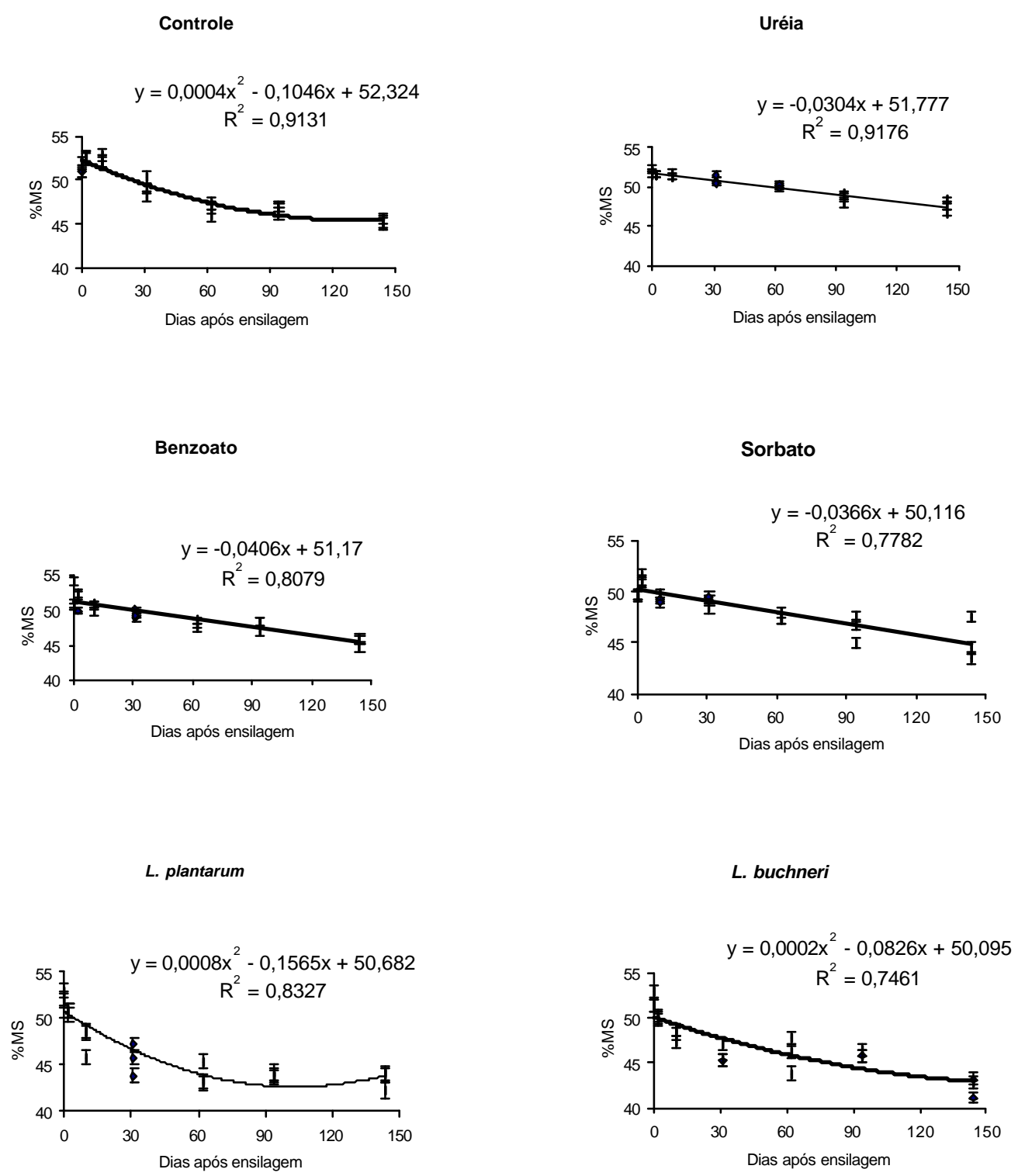

Figura 15 - Tendência temporal da digestibilidade verdadeira "in vitro" da MS (DVIVMS) (\% da MS) de silagens de cana-de-açúcar tratadas com aditivos químicos (uréia, benzoato de sódio, sorbato de potássio) e inoculantes microbianos ( $L$. plantarum, L. buchneri) 
É pertinente considerar-se que, a concentração de etanol que se obtém nas silagens, em estudos onde se utiliza silos que permitem o escape de gases, representa o resultado entre a produção e a perda por volatilização do álcool, e que o momento onde o etanol deixa de acumular na MS da silagem deve ser o ponto onde a taxa de perda supera a taxa de síntese, mas não representa, necessariamente, o término do processo de produção do álcool.

A variação temporal das concentrações de $\mathrm{CHOs}$ dos tratamentos avaliados (Figura 12) indica tendência inversa às curvas das concentrações de etanol e das perdas gasosas, evidenciando o consumo de açúcares e a perda elevada de MS característicos da processo fermentativo da cana-de-açúcar dominado por leveduras (Preston et al.,1976; Alli et al.,1982). O tratamento com L. buchneri resultou em tendência de maior perda de açúcares ao longo do tempo, confirmando dados da Tabela 8.

As tendências referentes às perdas totais de MS das silagens (Figura 13) indicam que os tratamentos com uréia e sorbato, apesar de não terem apresentado os maiores níveis de perdas gasosas, foram os que acumularam as maiores perdas totais de MS ao longo do período de ensilagem, confirmando dados da amostragem aos 94 dias (Tabela 8). Na Figura 14 constata-se que, coincidentemente, estes foram os tratamentos que apresentaram maior produção de efluentes, indicando que a perda de MS por esta via, que normalmente é considerada pequena para silagens com teor de MS superior a $28 \%$ (McDonald et al., 1991), pode contribuir significativamente para o aumento da perda total de MS das silagens. Levando-se em conta que as concentrações de CHOs residuais destes tratamentos foram semelhantes $(\mathrm{P}>0,05)$ à do controle, pode-se sugerir que outros compostos solúveis, como ácidos orgânicos, sais e compostos nitrogenados solúveis foram lixiviados em maior quantidade pelos efluentes destes tratamentos.

As DVIVMS das silagens dos tratamentos com uréia, benzoato esorbato (Figura 15) apresentaram tendência linear de decréscimo com o passar do tempo, provavelmente como efeito de uma tendência de produção crescente de efluentes destas silagens (Figura 14). 


\subsubsection{Efeito dos tratamentos sobre a estabilidade aeróbica das silagens}

Os valores de estabilidade aeróbica sofreram grande influência do tipo de tratamento a que as silagens foram submetidas (Figura 16). Da mesma forma, houve diferenças significativas $(\mathrm{P}<0,05)$ entre os tratamentos para ADITE-5 e ADITE-10 (vide definição no item 5.2.5). A silagem controle apresentou estabilidade aeróbica de 48 horas, ADITE- 5 de $41^{\circ} \mathrm{C}$ e ADITE- 10 de $89^{\circ} \mathrm{C}$, indicando menor estabilidade do que a obtida em avaliação realizada anteriormente (capítulo 4), onde a silagem produzida sem aditivos, com a mesma variedade de cana-de-açúcar colhida no mesmo estádio de desenvolvimento, apresentou estabilidade de 31 horas e ADITE-5 de $24^{\circ} \mathrm{C}$. A estabilidade aeróbica varia bastante entre os tipos de silagem, em função do teor de MS, de ácido acético e butírico e da contagem de leveduras (McDonald et al., 1991), encontrando-se valores na ordem de 37 ou $38 \mathrm{~h}$ para silagem de milho (Higginbotham et al.,1998; Ranjit et al., 2002) e de até 183 h em um experimento com silagem de capim azevém (Driehuis et al., 2000). O valor de estabilidade encontrado neste experimento para a silagem controle, contendo $28 \%$ de MS e 6,5 log ufc/g de MV de leveduras, esteve próximo ao relatado por Driehuis et al. (1999) que obteve 43 horas de estabilidade aeróbica para silagem de milho contendo teor de MS semelhante e 4,5 log ufc/g de MV de leveduras.

A aplicação do inoculante contendo L. buchneri resultou na silagem com maior estabilidade aeróbica (Figura 16), considerando-se em conjunto o tempo para o início do aquecimento e a intensidade do aquecimento após a perda da estabilidade. A silagem inoculada com estas bactérias demorou 78 horas até o início do aquecimento (63\% a mais do que o controle). Durante os primeiros 5 dias de exposição ao ar, este foi também o tratamento onde a silagem aqueceu menos intensamente, apresentando o menor ADITE-5 $\left(8^{\circ} \mathrm{C}\right) \quad(\mathrm{P}<0,05)$. Após o $5^{\circ}$ dia de aerobiose, esta silagem apresentou aquecimento mais intenso, apresentando ADITE-10 inferior apenas ao da silagem tratada com uréia e ao da silagem controle. Em avaliação anterior (capítulo 4) o uso deste inoculante resultou em silagem com estabilidade similar e ADITE-5 aproximadamente 3 vezes superior, indicando menor estabilidade naquele caso. Os 
resultados obtidos neste experimento estão de acordo, no entanto, com os resultados mais consistentes da literatura que indicam grande estabilidade aeróbica de silagens inoculadas com estas bactérias. Os resultados foram melhores do que os obtidos por Ranjit \& Kung, Jr. (2000) que, para o nível de aplicação da bactéria de 1 x $10^{5}$ ufc/g, obtiveram silagem de milho com estabilidade de apenas 36 horas. Devendo-se ressaltar que esses mesmos pesquisadores obtiveram silagem de milho estável por mais de 900 horas, com a aplicação do inoculante em dose suficiente para atingir $1 \times 10^{6} \mathrm{ufc} / \mathrm{g}$ de forragem da bactéria. Driehuis et al. (2001) obtiveram silagens de capim azevém (Lolium perenne) emurchecido, com estabilidade superior a 480 horas com a aplicação de L. buchneri em taxas de 1 x $10^{5}$ e $3 \times 10^{5} \mathrm{ufc/g}$. No entanto, a silagem não inoculada

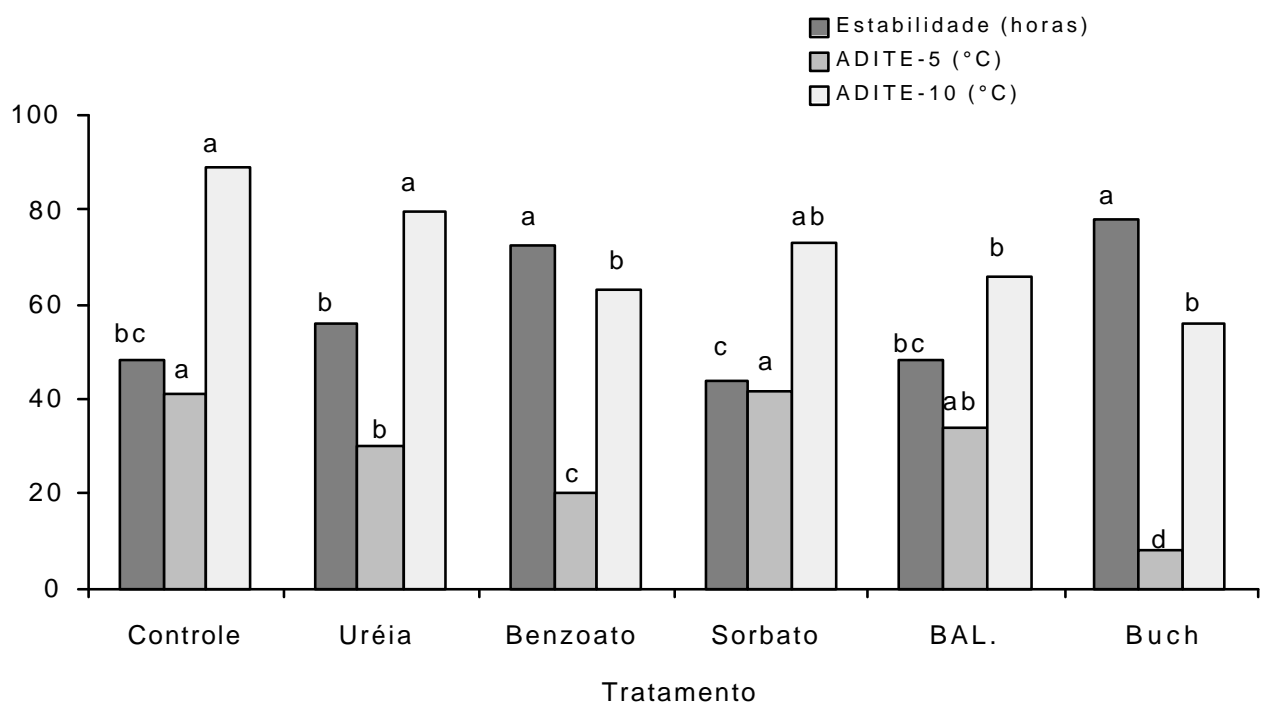

Figura 16 - Estabilidade aeróbica, ADITE- $5^{*}$ e ADITE- $10^{*}$ das silagens de cana-deaçúcar tratadas com Uréia, benzoato de sódio, sorbato de potássio e inoculantes contendo L. plantarum (BAL) e L. buchneri (Buch)

* Acúmulo da diferença média, entre a temperatura ambiente e a temperatura das silagens, nos primeiros 5 e 10 dias de exposição ao ar.

Letras diferentes, dentro de um mesmo parâmetro, indicam diferença significativa $\mathrm{P}<0,05$. 
apresentou 3,17\% de ácido acético na MS e estabilidade de 183 horas, tendo sido ressaltado pelos autores que a microflora epífita da silagem controle foi predominantemente composta por bactérias da espécie L. buchneri. Isto sugere que o nível de aplicação de $1 \times 10^{5} \mathrm{ufc/g}$ poderia não ter sido tão eficiente se não houvesse a ação conjunta das bactérias originalmente presentes na forragem.

A silagem tratada com benzoato apresentou o segundo melhor valor de estabilidade, demorando 72 horas para o início do aquecimento (50\% a mais que o controle) e apresentando ADITE-5 de $20,1^{\circ} \mathrm{C}$. Estes resultados foram melhores do que os obtidos em avaliação anterior (capítulo 4) onde este tratamento não apresentou diferença em relação à silagem sem aditivos. Os resultados estão de acordo com os de Lättemäe e Lingvall (1996) que, avaliando aditivos contendo benzoato de sódio combinado à hexamina na ensilagem de capim azevém emurchecido, observaram aumento significativo na estabilidade aeróbica com a aplicação do ácido, na dose de $0,15 \%$ do peso da forragem.

O efeito benéfico de redução da população de leveduras, obtido com os tratamentos das silagens com benzoato de sódio e L. buchneri (Tabela 8), prolongaramse durante a exposição das silagens ao ar (Figura 16), resultando em melhores índices de estabilidade aeróbica. Essa mesma tendência não foi observada para os tratamentos com uréia e sorbato que, apesar de terem reduzido a produção de etanol, não foram capazes de aumentar a estabilidade aeróbica em relação à silagem controle (P>0,05) (Figura 16). A silagem tratada com uréia apresentou $10^{\circ} \mathrm{C}$ a menos que o controle para o EDITE-5, no entanto, não houve diferença para o EDITE-10 ( $\mathrm{P}>0,05)$. Os resultados foram melhores, para o tratamento com uréia e piores para o tratamento com sorbato, em relação à avaliação anterior deste projeto (capítulo 4).

A estabilidade da silagem inoculada com L. plantarum (Figura 16) foi melhor do que a observada anteriormente (capítulo 4), onde a inoculação com bactérias homoláticas resultou em redução de $63 \%$ na estabilidade, e aumento de $26 \%$ no ADITE5 da silagem tratada, em relação ao controle. Os dados, em conjunto, indicam que a inoculação com bactérias homoláticas não traz benefícios em relação à estabilidade 
aeróbica, concordando com diversos relatos disponíveis na literatura (Higginbothan et al., 1998; Ranjit \& Kung, 2000).

\subsection{Conclusões}

Os aditivos testados mostraram capacidade de diminuir a produção de etanol nas silagens, com exceção do inoculante contendo L. plantarum, no entanto não foram capazes de diminuir as perdas totais de MS ou aumentar a DVIVMS, neste caso com exceção da uréia, em relação à silagem de cana-de-açúcar sem aditivos. O efeito ao longo do tempo, sobre a composição e as perdas de MS das silagens, mostrou-se variável entre os aditivos, com efeito sobre a qualidade final das silagens.

A intensidade de ação dos aditivos, nas diferentes formas de perdas de MS, não é constante. Com isso, a meta de redução no teor de etanol em silagens de cana-de-açúcar, como estratégia exclusiva, poderá não ser vantajosa, por não considerar efeitos compensatórios indesejáveis, como a diminuição da estabilidade aeróbica. Os aditivos benzoato de sódio e o inoculante contendo L. buchneri mostraram-se mais promissores por terem reduzido a produção de etanol e aumentado a estabilidade aeróbica das silagens.

Os dados permitem concluir ainda que as perdas de MS em silagens de cana-deaçúcar podem apresentar tendência de aumento linear com o aumento do período de ensilagem, levando à diminuição também linear da DVIVMS, mesmo com o uso de aditivos. Isto sugere que a estocagem por períodos de tempo prolongado pode resultar em perdas qualitativas e quantitativas excessivas em silagens de cana-de-açúcar, e que métodos eficientes de controle destas perdas precisam ser desenvolvidos. 


\section{DESEMPENHO DE NOVILHAS DA RAÇA HOLANDESA ALIMENTADAS \\ COM RAÇÕES A BASE DE SILAGENS DE \\ CANÁ-DE-ÇÚCAR ADITIVADAS}

\section{Resumo}

Trinta e duas novilhas holandesas, $388 \mathrm{~kg}$, foram alocadas a 4 tratamentos, com 4 repetições cada, em um delineamento em blocos. Durante o período experimental (60 dias), os animais foram alimentados com rações completas contendo (\% da MS): 45,9\% de silagem de cana; $15,0 \%$ de polpa de citros "peletizada"; $35,7 \%$ de milheto grão moído; $0,92 \%$ ( $\mathrm{p} /$ silagem com uréia) ou $1,55 \%$ de uréia e 1,84\% de suplemento mineral. As silagens foram produzidas com cana-de-açúcar, variedade RB78-5841, queimada no campo, colhida com colhedora acoplada ao trator e ensilada em silos "tipo poço" com capacidade para 12 toneladas cada. Os tratamentos consistiram em 4 tipos de ração, compostas com as seguintes silagens, de acordo com o aditivo utilizado: controle (sem aditivos); uréia ( $0,5 \%$ da MV); benzoato de sódio - BENZ $(0,1 \%$ da MV) e Lactobacillus buchneri - BUCH (3,64 x $10^{5}$ ufc/g MV). Uma camada de aproximadamente $10 \mathrm{~cm}$ de silagem foi retirada diariamente $(140 \mathrm{~kg})$ de cada silo, da qual calculourse a porcentagem de silagem deteriorada, com base em avaliação visual. Houve tendência $(\mathrm{P}=0,15)$ de maior ingestão de MS (IMS) para BUCH $(9,60 \mathrm{~kg} / \mathrm{dia}) \mathrm{em}$ relação ao controle $(8,71 \mathrm{~kg} / \mathrm{dia})$. O ganho de peso médio diário (GPD) mostrou aumento de $21 \%$ para BENZ $(\mathrm{P}<0,05)$ e de $32 \%$ para $\mathrm{BUCH}(\mathrm{P}<0,01)$, em comparação ao controle $(0,94 \mathrm{~kg} / \mathrm{d})$. Melhor conversão alimentar (IMS/GPD) foi observada para os tratamentos BENZ $(7,63)$ e BUCH $(7,72)$ em relação ao controle $(9,37)$. A IMS $(2,19 \%$ PV) e a porcentagem de silagem deteriorada (20\%), não diferiram $(\mathrm{P}>0,10)$ entre os tratamentos. $\mathrm{O}$ tratamento contendo silagem de cana-de-açúcar aditivada com uréia não 
diferiu $(\mathrm{P}>0,05)$ do controle, em nenhum dos parâmetros avaliados. Os resultados indicam que, desempenhos mais favoráveis podem ser obtidos em animais em crescimento alimentados com silagens de cana-de-açúcar aditivadas com L. buchneri ou benzoato de sódio.

\section{PERFORMANCE OF HOLSTEIN HEIFERS FED DIETS BASED ON SUGAR CANE SILAGE TREATED WITH UREA, SODIUM BENZOATE AND L. Buchneri}

\section{Summary}

Sugar cane was burned at field, chopped and ensiled in $12 \mathrm{t}$ pit silos. Sugar cane silage (SCS) treatments consisted of (wet basis): control (no additives); urea (0.5\%), sodium benzoate-BENZ (0.1\%) e Lactobacillus buchneri-BUCH $\left(3.64 \times 10^{5} \mathrm{cfu} \mathrm{g}^{-1}\right)$ applied onto forage during ensiling. Thirty two Holstein heifers $(388 \mathrm{~kg}$ ) were allocated to 4 treatments, 4 replications each, in a block design. During the feeding period $(60 \mathrm{~d})$ the animals were fed daily total mixed rations containing $45.9 \%$ SCS, $15 \%$ pelleted citrus pulp, $35.7 \%$ ground pearl millet grain, $0.9 \%$ (urea treated silage) or $1.6 \%$ urea and $1.8 \%$ premix as DM basis. The silage layer $(10 \mathrm{~cm})$ unloaded daily averaged $140 \mathrm{~kg}$, from which spoiled silage percentage was calculated. There was a trend $(\mathrm{P}=0.15)$ for increased DMI (kg/d) in BUCH SCS (9.6) over control SCS (8.7). Average daily gain (ADG) showed $21 \%$ increase $(\mathrm{P}<0.05)$ for $\mathrm{BENZ}$ and $32 \%$ for $\mathrm{BUCH}$ SCS over control $(0.94 \mathrm{~kg} / \mathrm{d})$. Better feed conversion (DMI/ADG) were observed for BENZ and BUCH SCS (7.6 and 7.7 vs 9.37); DM intake (2.2\% BW) did not differ ( $>0.10)$ across treatments. Urea treated silage was similar to control in all traits evaluated $(\mathrm{P}>0.05)$. It suggests that improved animal performance might be achieved either by adding $L$. buchneri or sodium benzoate at the ensiling of sugar cane. 


\subsection{Introdução}

A ensilagem da cana-de-açúcar tem sido realizada pelos pecuaristas, para facilitar o manejo da alimentação dos rebanhos e dos canaviais e também na ocorrência de incêndios e geadas, para se evitar a perda da forragem. No entanto, silagens de cana produzidas sem a utilização de aditivos que controlem a produção de etanol, têm resultado em forragens de baixa qualidade, não permitindo desempenho adequado dos animais com elas alimentados, apresentando perdas excessivas de matéria seca e de valor nutritivo durante a conservação (Alli et al., 1982; Kung, Jr. e Stanley, 1982; Coan et al., 2002).

A aplicação de aditivos, como a uréia, pode melhorar a qualidade das silagens de cana-de-açúcar, diminuindo a população de leveduras e mofos, reduzindo a produção de etanol, as perdas de MS e de carboidratos solúveis e propiciando melhor composição bromatológica nas silagens tratadas, em comparação a silagens de cana exclusiva (Alli et al., 1983; Lima et al., 2002). O ácido benzóico tem demonstrado efeito inibitório sobre leveduras e mofos e a capacidade de melhorar a conservação e a estabilidade aeróbica das silagens tratadas (Ohyama et al., 1975; Lättemäe e Lingvall, 1996). Estes produtos foram avaliados como aditivos para silagens de cana-de-açúcar em fases anteriores deste projeto de pesquisa (Capítulos 4 e 5), tendo sido constatada redução significativa na produção de etanol, na perda total de MS e efeito positivo sobre a DVIVMS e a estabilidade aeróbica das silagens.

Inoculantes microbianos contendo as bactérias heterofermentativas L. buchneri, que produzem ácido acético além do ácido lático, têm se mostrado capazes de reduzir a população de leveduras e aumentar a estabilidade aeróbica de silagens de milho e de gramíneas de clima temperado (Ranjit and Kung, Jr., 2000, Taylor et al., 2002). A avaliação do seu uso na ensilagem da cana-de-açúcar, resultou em aumento na recuperação de MS, redução na produção de etanol e aumento da estabilidade aeróbica das silagens (Capítulos 4 e 5).

O presente experimento tem como objetivo avaliar o desempenho de bovinos em crescimento, alimentados com rações contendo silagens de cana-de-açúcar tratadas com 
uréia, benzoato de sódio ou com inoculante bacteriano contendo uma cepa das bactérias heterofermentativas Lactobacillus buchneri.

\subsection{Material e Métodos}

\subsubsection{Produção e tratamento das silagens}

O experimento foi conduzido, no período de janeiro a março de 2003, no Departamento de Zootecnia, Setor de Ruminantes, da ESALQ/USP em Piracicaba, SP. A cana-de-açúcar, variedade RB78-5841, foi queimada no campo, colhida com colhedora acoplada ao trator, marca Mentamit $^{\circledR}$, regulada para corte com tamanho de partículas médio entre 5 a $10 \mathrm{~mm}$. A queima foi realizada no dia 8 e a ensilagem nos dias 9 a 11 de outubro de 2002, em silos do tipo "poço" com capacidade para 12 toneladas cada.

Os aditivos utilizados na ensilagem foram a uréia, na forma de fertilizante granulado contendo $45 \%$ de N, o benzoato de sódio, na forma granulada solúvel, e um inoculante bacteriano não comercial, contendo bactérias heteroláticas Lactobacillus buchneri, cepa NCIMB 40788, fornecido pela Biotal ${ }^{\circledR} \operatorname{Ltd}$ (Cardiff, UK).

Soluções aquosas do benzoato de sódio e do inoculante contendo L. buchneri foram pulverizadas sobre a cana-de-açúcar picada, no momento em que esta era carregada nos silos, utilizando-se água bi-destilada para a aplicação do inoculante bacteriano. As pulverizações foram realizadas utilizando-se equipamentos manuais com capacidade para cinco e $10 \mathrm{~L}$, da marca Brudden $^{\circledR}$ (Brudden Equipamentos Ltda). O benzoato de sódio foi aplicado na dose de $0,1 \%$ em relação ao peso da forragem verde, utilizando-se $13 \mathrm{~L}$ de solução/t, e o inoculante bacteriano foi aplicado, de acordo com a recomendação do fabricante, em quantidade suficiente para obtenção de $3,64 \times 10^{5}$ unidades formadoras de colônias - ufc/g de massa verde-MV, utilizando-se 1,89 L de solução/t. A uréia foi aplicada, manualmente e a granel, em pequenas quantidades sobre a forragem, à medida que esta era carregada no silo. A dosagem dos aditivos foi realizada, calculando-se a quantidade necessária para o tratamento da forragem contida 
nos vagões forrageiros utilizados no transporte (tendo sido estimada a densidade de 300 $\mathrm{kg} / \mathrm{m}^{3}$ para a forragem nos mesmos), considerando-se as concentrações desejadas dos aditivos nas silagens.

A ensilagem foi realizada, compactando-se sucessivamente camadas de aproximadamente $20 \mathrm{~cm}$ da forragem com os pés. Apesar da tentativa de ensilagem simultânea da cana-de-açúcar nos diversos tratamentos, o silo do tratamento controle teve seu enchimento completado no primeiro dia, por ter capacidade de estocagem menor que os demais, o silo do tratamento com uréia foi completado no final do segundo dia e os demais na tarde do terceiro dia.

\subsubsection{Animais e instalações experimentais}

O desempenho foi avaliado em 32 novilhas da raça holandesa, com idades variando entre sete e meio e 24 meses, distribuídas em quatro blocos de oito animais cada, sendo o peso médio em cada bloco de 495, 448, 391 e $220 \mathrm{~kg}$. As novilhas foram mantidas em baias de $33 \mathrm{~m}^{2}$ ( $\left.3 \times 11 \mathrm{~m}\right)$, cobertas e providas de piso de concreto, bebedouros e cochos em alvenaria. Foram alojados dois animais por baia, num total de 16 baias. Dentro de cada bloco, os animais foram alocados nas baias de forma a se obter a menor variação possível entre os pesos médios nas baias. Para isso, o animal mais pesado do bloco foi alojado com o animal mais leve, o animal com o segundo maior peso foi alojado com o animal com o segundo menor peso, e assim sucessivamente.

As novilhas receberam tratamento sanitário, everminação e controle de carrapatos, como parte do manejo rotineiro do rebanho, antes do início do experimento.

\subsubsection{Tratamentos e manejo da alimentação}

Foram avaliados quatro tipos de ração, que diferiram quanto ao tipo de silagem de cana-de-açúcar utilizado nas suas composições, como segue: silagem sem aditivo (controle) ou silagens tratadas com benzoato de sódio (0,1\% MV), L. buchneri (3,64 x $10^{5}$ ufc/g de MV) ou uréia (0,5\% MV). Dois tipos básicos de ração (Tabela 10) foram 
formulados por meio do programa do NRC - Gado de Leite (2001), visando-se ganho de peso médio diário de $0,850 \mathrm{~kg}$ para novilhas holandesas em crescimento, pesando 450 $\mathrm{kg}$. As rações foram formuladas para serem isoprotéicas (12\% PB) e isoenergéticas (70\% NDT), tendo sido considerados o valor hipotético de 53\% de NDT para as silagens de cana-de-açúcar e a prévia adição de uréia no respectivo tratamento.

Tabela 10. Participação de ingredientes nas rações experimentais em função do tipo de silagem de cana-de-açúcar utilizada

\begin{tabular}{lcc}
\hline Componentes (\% MS) & Silagem sem uréia & Silagens com 0,5\% de uréia \\
\hline Silagem de cana-de-açúcar & 45,9 & 46,2 \\
Milheto grão moído & 35,7 & 35,9 \\
Polpa cítrica "peletizada" & 15,0 & 15,1 \\
Uréia & 1,55 & 0,92 \\
Suplemento mineral & 1,84 & 1,85
\end{tabular}

Os ingredientes concentrados das rações foram misturados com antecedência, em quantidade suficiente para o arraçoamento de uma semana, utilizando-se misturador horizontal, da marca Lucato $^{\circledR}$, com capacidade para $250 \mathrm{~kg}$. As dietas foram fornecidas uma vez por dia, aproximadamente às 18:00 horas, sendo a silagem e o concentrado, referentes a cada baia, pesados em balança eletrônica (marca Marte ${ }^{\circledR}$, de capacidade até $50 \mathrm{~kg}$ ), ensacados, para o transporte até as instalações do confinamento, e misturados manualmente nos cochos.

As sobras de alimentos de cada baia foram quantificadas diariamente, possibilitando o cálculo posterior do consumo e ajuste da quantidade de alimento a ser fornecida em cada dia, tendo-se em vista o consumo "ad libitum" da dieta, o que resultou em aproximadamente $15 \%$ de sobras, em média. 


\subsubsection{Período experimental, avaliação do consumo e pesagens dos animais}

O período experimental de 60 dias, com início em 16 de janeiro e final em 15 de março de 2003, foi subdividido em dois períodos de 30 dias para controle do desenvolvimento dos animais.

O consumo diário de MS das dietas foi calculado pela diferença entre a quantidade de MS fornecida e a quantidade de MS das sobras, de cada baia. $\mathrm{O}$ teor de MS da dieta e das sobras foi determinado semanalmente, por meio da secagem de amostras em estufa com ventilação forçada $\left(60^{\circ} \mathrm{C}\right)$ por 48 horas.

O ganho de peso diário foi avaliado pesando-se os animais no primeiro dia e ao final dos dois sub-períodos experimentais, após jejum alimentar de 12 horas.

\subsubsection{Análises químico-bromatológicas}

Amostras foram retiradas da cana-de-açúcar queimada e picada, antes da ensilagem, das silagens e das sobras, uma vez por semana, para análise da composição químico-bromatológica. As amostras para determinação do teor de carboidratos solúveis em água (CHOs), pH e etanol, foram congeladas $\left(-10^{\circ} \mathrm{C}\right)$ e as destinadas às demais análises foram secas em estufa com ventilação forçada $\left(60^{\circ} \mathrm{C}\right)$ por 48 horas.

As amostras secas foram moídas contra peneira de malha de $1 \mathrm{~mm}$ e posteriormente analisadas pelo método da espectroscopia de reflectância de infravermelho proximal (NIRS) (Berzaghi et al., 1997; Cozzolino et al., 2001) utilizando-se um espectrofotômetro modelo NIRS $5000^{\circledR}$ (NIRSystems, Silver Spring, MD, USA). A análise utilizou comprimentos de onda entre 700 e $2100 \mathrm{~nm}$ e os espectros das amostras "escaneadas" foram armazenados em curvas log (1/R) em intervalos de 2nm. O método de seleção existente no "software" do equipamento identificou as amostras distantes mais de $3 \mathrm{H}$ (distância padronizada de Mahalanobis) da média, “outliers", que foram excluídas. Adotando-se uma distância mínima de 0,6 H entre amostras (Shenk \& Westerhaus, 1991), foram selecionadas as que deveriam ser analisadas pelos métodos da bromatologia convencional. De posse dos resultados destas 
análises, o programa do equipamento NIRS foi capaz de inferir a composição química e bromatológica das demais amostras.

As análises das amostras selecionadas pelo método NIRS foram realizadas como segue:

- matéria seca em estufa a $105{ }^{\circ} \mathrm{C}$ por 8 horas.

- a matéria mineral (cinzas) foi obtida pela incineração das amostras em mufla a $600{ }^{\circ} \mathrm{C}$ por 3 horas.

- os teores de fibra em detergente neutro (FDN) e a digestibilidade verdadeira "in vitro" matéria seca (DVIVMS) foram determinados através do método ANKON $^{\circledR}$ Fiber Analyser (ANKON Technology Corporation, Fairport, NY).

- os teores de fibra em detergente ácido (FDA) e de lignina (LIG) foram avaliados segundo os métodos propostos por Van Soest et al. (1991) e a proteína bruta (PB) segundo AOAC (1984).

- o teor de PB para o tratamento com uréia foi determinado pelo método macro Kjeldahl (AOAC, 1984), em amostras úmidas de silagem que haviam sido mantidas congeladas $\left(-5^{\circ} \mathrm{C}\right)$.

Os teores de etanol e de CHOs foram determinados em extratos aquosos das silagens, obtidos segundo método descrito por Kung, Jr. (1996). Para isto, $25 \mathrm{~g}$ de amostra úmida foram processados com $225 \mathrm{~mL}$ de água destilada, em liquidificador, durante um minuto. Em seguida, o material foi filtrado em papel de filtro Whatman ${ }^{\circledR} 54$, acidificado com $\mathrm{H}_{2} \mathrm{SO}_{4}$ a $50 \%$ e centrifugado, sendo o extrato líquido armazena do em congelador $\left(-5^{\circ} \mathrm{C}\right)$ até o momento das análises. $\mathrm{O} \mathrm{pH}$ foi determinado nos extratos aquosos, antes da filtragem, através de um potenciômetro digital da marca Digimed ${ }^{\circledR}$, modelo DM 20. As análises do teor de etanol foram realizadas nos laboratórios do Setor de Açúcar e Álcool do Departamento de Agroindústria Alimentos e Nutrição da ESALQ/USP de Piracicaba, por meio de cromatógrafo a gases com detector de ionização de chama, marca Gregório e Cioli ${ }^{\circledR}$, modelo CG-37D. As determinações dos teores de CHOs foram realizadas pelo método colorimétrico de Dubois et al. (1956), diluindo-se os extratos aquosos das amostras de silagens, na proporção de $1 \mathrm{~mL}$ de extrato para $20 \mathrm{~mL}$ de água destilada. 


\subsubsection{Análise estatística}

O delineamento experimental utilizado foi o de blocos casualizados, com quatro tratamentos, quatro repetições por tratamento e dois animais por baia (unidade experimental). Os blocos foram arranjados de acordo com o peso inicial dos animais.

O modelo proposto considerou os efeitos de bloco, de tratamentos e as interações, sendo analisado segundo o procedimento GLM do programa SAS (SAS, 1988). A comparação das médias foi realizada pelo teste de quadrados mínimos (LSMEANS).

\subsection{Resultados e Discussão}

A cana-de-açúcar queimada, utilizada para a produção das silagens, apresentou teores de FDN, FDA e lignina (Tabela 11) dentro dos níveis encontrados em variedades atualmente recomendadas para produção de açúcar e álcool (Andrade et al., 2002). A DVIVMS apresentou-se reduzida em comparação aos valores relatados por Rodrigues et al. (2001), que na avaliação de 18 variedades da cana-de-açúcar, como alimento para bovinos, encontraram DVIVMS acima de 58\%, no entanto, a relação FDN/CHOs, de 1,79 , foi melhor do que as encontradas para as melhores variedades avaliadas por aqueles autores $(2,88)$.

$\mathrm{Na}$ avaliação da composição química das silagens (Tabela 11) nota-se que, a concentração de etanol esteve abaixo da expectativa, contrariando dados da literatura onde encontram-se valores entre 5,5 e 15,5\% de etanol para silagens de cana-de-açúcar sem aditivos (Preston et al., 1976; Kung Jr. \& Stanley, 1982). Pode-se supor que tal fato deveu-se à volatilização do álcool, das camadas superiores das silagens, uma vez que a retirada média diária foi de apenas $10 \mathrm{~cm}$ de profundidade, em cada silo. $\mathrm{O}$ forte odor de álcool presente no interior dos silos, constatado pelas pessoas encarregadas da retirada das silagens, leva também à suposição de que houve produção de etanol superior àquela detectada nas análises das amostras. 
Tabela 11. Composição bromatológica da cana-de-açúcar, queimada e picada, antes da ensilagem, e das silagens experimentais

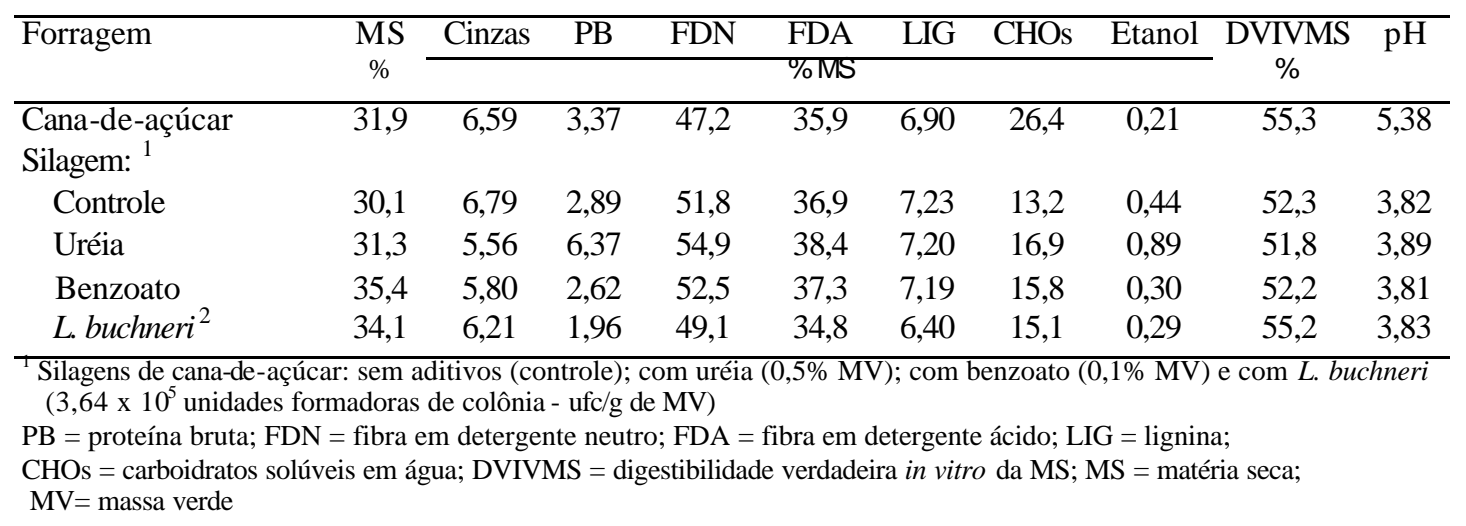

A ensilagem da cana-de-açúcar sem o uso de aditivos (controle) resultou em redução de 50\% na concentração de CHOs da forragem e de 5,4\% na DVIVMS (Tabela 11), valores que se assemelham aos encontrados em etapas anteriores deste projeto (Capítulo 5). O teor de MS e o pH foram mais elevados, e os teores dos componentes da fibra e de PB foram menores, do que os relatados por Coan et al. (2002) e Bernardes et al. (2002) que, para silagem de cana queimada, colhida aos doze meses de rebrota e estocada por 55 dias, encontraram teor de MS de 20,1\%, pH de 3,67 e teores de FDN, FDA e lignina de $53,2 \%, 41,5 \%$ e $8,3 \%$, respectivamente.

O desempenho das novilhas (Tabela 12) alimentadas com a ração contendo silagem de cana sem aditivos, foi inferior em relação ao desempenho freqüentemente observado para bovinos recebendo dietas contendo cana-de-açúcar fresca, como volumoso exclusivo, em proporção semelhante ou maior à utilizada no presente trabalho. $\mathrm{Na}$ literatura são encontrados valores de ganho de peso diário de até 1,81 kg para animais alimentados com ração contendo $48 \%$ da MS na forma de cana-de-açúcar fesca (Hernandez, 1998).

São escassos os trabalhos de pesquisa onde se avaliou o desempenho de bovinos alimentados com silagem de cana-de-açúcar sem aditivos. $O$ consumo da silagem não aditivada neste experimento, de aproximadamente $13,3 \mathrm{~kg} / \mathrm{animal} / \mathrm{dia}$, pode ser comparado ao relatado por Silvestre et al. (1976) que, para novilhos mais leves (200 kg de peso inicial), obtiveram consumo de aproximadamente $11,5 \mathrm{~kg}$ de 
silagem/animal/dia. Utilizando rações contendo quantidade menor de concentrado $(0,5$ $\mathrm{kg}$ de farelo de arroz/animal/dia), numa avaliação com novilhos pesando $300 \mathrm{~kg}$ inicialmente, Alvarez et al. (1977) detectaram consumo semelhante de silagem (13,5 $\mathrm{kg} / \mathrm{animal} / \mathrm{dia})$, mas o ganho de peso $(0,327 \mathrm{~kg} / \mathrm{dia})$ e a conversão alimentar $(15,0)$ foram inferiores. A conversão alimentar foi também superior àquela obtida por Valvasori et al. (1998) que, para bezerros com peso médio inicial de $97 \mathrm{~kg}$, recebendo dieta contendo aproximadamente $60 \%$ de silagem de cana, constataram consumo de 12,4 kg MS para cada quilo de ganho de peso vivo.

Tabela 12. Desempenho de novilhas da raça holandesa alimentadas com rações contendo silagens de cana-de-açúcar aditivadas

\begin{tabular}{|c|c|c|c|c|c|c|}
\hline Tratamentos & $\begin{array}{l}\text { Peso } \\
\text { inicial }\end{array}$ & $\begin{array}{l}\text { Peso } \\
\text { final }\end{array}$ & $\begin{array}{c}\text { Ganho } \\
\text { diário }\end{array}$ & $\begin{array}{c}\text { Consumo de } \\
\text { MS }\end{array}$ & $\begin{array}{c}\text { Consumo de } \\
\text { MS }\end{array}$ & Conversão \\
\hline & \multicolumn{3}{|c|}{ (kg) } & (Kg/dia) & $(\% \mathrm{PV})^{2}$ & (Kg MS/kg GPD) \\
\hline Controle & $387,3^{a}$ & $443,5^{b}$ & $0,94^{b}$ & $8,72^{a}$ & $2,15^{a}$ & $9,37^{a}$ \\
\hline Uréia & $391,5^{a}$ & $453,8^{a b}$ & $1,03^{b}$ & $8,75^{\circ}$ & $2,17^{\mathrm{a}}$ & $8,63^{a b}$ \\
\hline Benzoato & $383,3^{a}$ & $468,5^{a}$ & $1,14^{\mathrm{ab}}$ & $8,61^{a}$ & $2,12^{a}$ & $7,63^{b}$ \\
\hline L. buchneri & $391,4^{a}$ & $465,8^{a}$ & $1,24^{a}$ & $9,61^{\mathrm{a}}$ & $2,35^{a}$ & $7,73^{b}$ \\
\hline Média & 388,3 & 457,9 & 1,09 & 8,92 & 2,19 & 8,34 \\
\hline$E P M$ & 6,18 & 5,84 & 0,06 & 0,40 & 0,11 & 0,53 \\
\hline
\end{tabular}

Os animais alimentados com a ração contendo silagem de cana-de-açúcar inoculada com L. buchneri apresentaram tendência de maior consumo $(\mathrm{P}=0,15)$, ganho de peso médio diário 31,9\% maior $(\mathrm{P}<0,05)$ e melhor conversão alimentar $(\mathrm{P}<0,05)$, em relação aos alimentados com a ração controle, tendo consumido 17,5\% a menos em MS por $\mathrm{kg}$ de ganho de peso vivo (Tabela 12). O ganho de peso foi 6,0\% maior do que o obtido por Pate $^{3}$ (citado por Boin \& Tedeschi, 1993) que, avaliando o desempenho de novilhos com peso inicial de $255 \mathrm{~kg}$ e alimentados com dieta contendo $58 \%$ de cana-deaçúcar fresca e $12 \%$ de PB na MS, obtiveram ganho de peso diário de $1,17 \mathrm{~kg}$. A conversão alimentar, no entanto, foi inferior à obtida por aquele pesquisador 
(7,73 vs $6,89 \mathrm{~kg} \mathrm{MS} / \mathrm{kg}$ d e ganho de peso). Os resultados indicam que, a diferença na composição bromatológica da silagem inoculada com L. buchneri em relação à silagem controle, com menor conteúdo dos componentes da fibra, maior concentração de CHOs e maior DVIVMS, foi suficiente para causar diferença significativa no desempenho.

Avaliações anteriormente realizadas durante a execução deste projeto (Capítulos 4 e 5) mostraram que a inoculação de silagens com L. buchneri pode ser eficiente na redução da produção de etanol em silagens de cana-de-açúcar, mas o efeito sobre a composição bromatológica das silagens tem sido variável, tendo resultado em menor perda total de MS e menor teor de FDN, mas causando maior consumo de CHOs durante a fermentação e não promovendo melhora significativa na DVIVMS da forragem tratada. Por outro lado, em sido consistente o efeito benéfico da inoculação com estas bactérias sobre a estabilidade aeróbica das silagens, de gramíneas em geral (Ranjit \& Kung Jr., 2000; Driehuis et al., 2001), bem como de silagens de cana-de-açúcar, como foi observado em etapas anteriores deste projeto (Capítulos 4 e 5), onde a inoculação produziu silagens que permaneceram estáveis por aproximadamente 80 horas, após a abertura dos silos. Considerando-se que a taxa de retirada das silagens neste experimento foi reduzida (aproximadamente $10 \mathrm{~cm} / \mathrm{dia}$ ), levando as silagens à exposição por tempo prolongado ao ar, pode-se sugerir que a silagem inoculada com L. buchneri tenha preservado melhor seu valor nutritivo, em relação à silagem controle, devido à maior estabilidade aeróbica, resultando assim em melhor desempenho dos animais com ela alimentados. Além disso, como hipótese para investigação futura, poderia se sugerir a possibilidade de efeito "probiótico" do L. buchneri, fato que poderia auxiliar na explicação dos desempenhos favoráveis aqui obtidos.

A ração contendo silagem tratada com benzoato de sódio resultou em melhor conversão alimentar $(\mathrm{P}<0,05)$ pelos animais, que consumiram 18,6\% menos MS da ração para cada $\mathrm{kg}$ de ganho de peso vivo, em relação aos animais alimentados com a ração controle. Houve tendência de maior ganho de peso diário $(\mathrm{P}=0,06)$ para os animais deste tratamento, sendo que no geral, a silagem tratada com benzoato apresentou resultados semelhantes $(\mathrm{P}>0,05)$ aos da silagem tratada com o inoculante bacteriano(Tabela 12). 
Em avaliações anteriores do tratamento de silagens de cana com sais de ácido benzóico (Capítulos 4 e 5), observou-se que este aditivo é capaz de reduzir a produção de etanol, entretanto os efeitos sobre a concentração de fibra e a DVIVMS das silagens tratadas foram variáveis. Em uma das avaliações realizadas (Capítulo 5) a utilização do aditivo causou redução no consumo de CHOs durante a fermentação e aumento significativo na estabilidade aeróbica da silagem, confirmando informações de Lättemäe \& Lingvall (1996). Esses pesquisadores forneceram dados indicando que o uso de aditivo contendo benzoato de sódio, promoveu melhor padrão de fermentação das silagens, principalmente em situação de penetração excessiva de ar nos silos. Os fatos expostos sugerem que, o uso do benzoato, neste experimento, deve ter resultado em efeitos benéficos sobre a preservação do valor nutritivo da silagem excessivamente exposta ao ar, que não foram detectados na análise bromatológica (Tabela 11), mas que possibilitaram certo grau de melhoria no desempenho dos animais com ela alimentados, em relação aos do tratamento controle.

O desempenho dos animais alimentados com a ração contendo silagem tratada com uréia, não diferiu $(\mathrm{P}>0,05)$ em nenhum dos aspectos avaliados em relação aos dos animais alimentados com a silagem controle (Tabela ).

Trabalhos de pesquisa têm demonstrado que o tratamento de silagens de cana-deaçúcar com $0,5 \%$ de uréia pode resultar em silagens de melhor qualidade, em relação a silagens não aditivadas, com menor teor de fibra e maior teor de PB (Lima et al., 2002; Molina et al., 2002). Os resultados de avaliações prévias realizadas neste projeto (Capítulos 4 e 5), confirmaram estes dados e indicam ainda, que o aditivo pode diminuir a produção de etanol e resultar em silagens com maior DVIVMS, em relação a silagens não aditivadas. A análise bromatológica da silagem tratada com uréia indica, no entanto, maiores valores numéricos de FDN, FDA e menor DVIVMS, em relação à silagem controle, apesar da maior concentração numérica de CHOs (Tabela 1), podendo assim explicar a ausência de efeito do tratamento sobre o desempenho dos animais.

A pior qualidade da silagem tratada com uréia pode ter sido decorrente da perda de valor nutritivo, como conseqüência da exposição prolongada ao ar a que foram submetidas as silagens neste experimento. Em outra etapa deste trabalho (Capítulo 4) 
constatou-se que silagens de cana-de-açúcar tratadas com 0,5\% de uréia podem apresentar menor estabilidade aeróbica em relação a silagens sem aditivos, contrariando o conceito generalizado de que o tratamento com uréia aumenta a estabilidade aeróbica das silagens (Rotz \& Muck, 1994; Bolsen et al, 1995). Estes aspectos, e o fato de que o tratamento com $1,5 \%$ do aditivo mostrou-se promissor quanto ao aumento da estabilidade aeróbica de silagens de cana-de-açúcar (Capítulo 4), indicam que devem ser desenvolvidas pesquisas, que avaliem o desempenho de animais recebendo silagens de cana-de-açúcar aditivadas com maiores doses de uréia, já que a deterioração aeróbica das silagens ocorre com grande frequiência nas propriedades (Ranjit \& Kung Jr., 2000), sendo um fator importante a ser considerado pelos pesquisadores e pecuaristas.

Tabela 13. Desempenho observado e estimado, com base nos valores reais dos pesos médios dos animais e de composição química das silagens, de novilhas holandesas em crescimento

\begin{tabular}{|c|c|c|c|c|c|}
\hline \multirow[t]{3}{*}{ Tratamento } & \multicolumn{3}{|c|}{ Observado } & \multicolumn{2}{|c|}{ Estimado } \\
\hline & Peso médio & Consumo MS & Ganho diário & Consumo MS & $\begin{array}{l}\text { Ganho } \\
\text { diário }\end{array}$ \\
\hline & & & $\mathrm{kg}$ & & \\
\hline Controle & 415 & 8,72 & 0,94 & 10,7 & 0,87 \\
\hline Uréia & 423 & 8,75 & 1,03 & 10,9 & 0,86 \\
\hline Benzoato & 426 & 8,61 & 1,14 & 10,9 & 0,83 \\
\hline L. buchneri & 429 & 9,61 & 1,24 & 11,0 & 1,08 \\
\hline Média & 423 & 8,92 & 1,09 & 10,9 & 0,91 \\
\hline
\end{tabular}

Utilizando-se os valores da composição química das silagens e os pesos médios obtidos para os animais de cada tratamento, estimou-se quais deveriam ser os valores de consumo e ganho de peso dos animais alimentados com cada tipo de ração, utilizando-se o programa de cálculo de rações do NRC - Gado de Leite (2001), que podem ser comparados aos que foram observados, na Tabela 13. Pode-se observar que o consumo de MS foi, aproximadamente, $18 \%$ menor e o ganho de peso $20 \%$ maior, em média, do que os calculados através do programa, sugerindo que as silagens devem ter apresentado valor nutritivo superior àquele considerado nos cálculos, onde utilizou-se apenas os 
valores de FDN, FDA, lignina, PB e de cinzas, tomando-se outros valores de tabelas, sem levar em conta os teores e o valor energético do etanol, dos ácidos graxos voláteis, do ácido lático, e de outros produtos da fermentação, que não puderam ser determinados. Os baixos teores de etanol, detectados na análise das silagens, indicam, no entanto, que este componente não deve ter contribuído significativamente para o aumento do valor energético das silagens neste experimento, e que outros fatores estariam envolvidos.

\subsection{Conclusões}

Os resultados deste experimento permitem concluir que os indicadores de desempenho de bovinos em crescimento, alimentados com rações contendo silagens de cana-de-açúcar tratadas com benzoato de sódio ou inoculantes contendo L. buchneri, podem ser superiores aos de animais recebendo silagens não aditivadas. 


\section{CONCLUSÕES GERAIS}

A cana-de-açúcar quando ensilada sem aditivos apresenta fermentação caracterizada por elevada produção de etanol, resultando em perdas excessivas de matéria seca e de valor nutritivo, com baixo consumo voluntário da forragem pelos animais. Alguns aditivos empregados mostraram-se capazes de reduzir a produção de etanol e de diminuir as perdas de componentes nutritivos durante a ensilagem, apesar dos resultados tendo sido variáveis. A incapacidade de alguns aditivos, em evitar a deterioração aeróbica das silagens, pode comprometer a obtenção de resultados satisfatórios de desempenho animal.

A utilização de inoculante contendo bactérias homoláticas (L. plantarum) mostrou-se prejudicial ao processo de conservação da cana-de-açúcar, aumentando a produção de etanol e as perdas de nutrientes da silagem.

A ensilagem da cana-de-açúcar com benzoato de sódio e L. buchneri resultou em forragens com maior valor nutritivo, propiciando maior ganho de peso e melhor conversão alimentar de bovinos em crescimento, provavelmente devido ao aumento da estabilidade aeróbica das silagens. 


\section{REFERÊNCIAS BIBLIOGRÁFICAS}

ALCÁNTARA, E.; AGUILERA, A.; ELLIOT, R.; SHIMADA, A. Fermentation and utilization by lambs of sugarcane harvested fresh and ensiled with and without $\mathrm{NaOH}$. 4. Ruminal kinetics. Animal Feed Science and Technology, v. 23, p. 323$331,1989$.

ALLI, I.; BAKER, B.E. Studies on the fermentation of chopped sugarcane. Animal Feed Science and Technology, v. 7, p. 411-417, 1982.

ALLI, I.; FAIRBAIRN, R.; BAKER, B.E. The effects of ammonia on the fermentation of chopped sugarcane. Animal Feed Science and Technology, v. 9, p. 291-299, 1983.

ALVAREZ, F.J.; PRESTON, T.R. Ammonia/molasses and urea/molasses as additives for ensiled sugar cane. Tropical Animal Production, v. 1, p. 98-104, 1976.

ALVAREZ, F.J.; PRIEGO, A; PRESTON, T.R. Animal performance on ensiled sugar cane. Tropical Animal Production, v. 2, p.2-33, 1977. 
ANDRADE, J.B.; JÚNIOR, E.F.; POSSENTI, R.A.; LEINZ, F.F.; BIANCHINI, D.; RODRIGUES, C.F.C. Valor nutritivo de silagem de cana-de-açúcar, cortada aos 7 meses de idade, tratada com uréia e adicionada de rolão de milho (compact disc). In: REUNIÃO DA SOCIEDADE BRASILEIRA DE ZOOTECNIA, 38., Piracicaba, 2001. Anais. Piracicaba: SBZ, 2001.

ANDRADE, J.B.; JÚNIOR, E.F.; POSSENTI, R.A.; OTSUK, I.P.; ZIMBACK, L.; LANDELL, M.G.A. Produção e composição de cultivares de cana-de-açúcar (compact disc). In: REUNIÃO DA SOCIEDADE BRASILEIRA DE ZOOTECNIA, 39., Recife, 2002. Anais. Recife: SBZ, 2002.

ASHBELL, G.; PAHLOW, G.; DINTER, B.; WEINBERG, Z.G. Dynamics of orange peel fermentation during ensilage. Journal of Applied Bacteriology, v. 63, p. 275$279,1987$.

ASSOCIATION OF OFFICIAL ANALYTICAL CHEMISTIS. Official methods of analysis. 15. ed. Arlington, 1990. v.1, 1117p.

BERNARDES, T.F.; SILVEIRA, R.N.; COAN, R.M.; REIS, R.A.; MOREIRA, A.L.; ITURRINO, R.P.S. Características fermentativas e presença de levedura na cana-deaçúcar crua ou queimada ensilada com aditivo (compact disc). In: REUNIÃO DA SOCIEDADE BRASILEIRA DE ZOOTECNIA, 39., Recife, 2002. Anais. Recife: SBZ, 2002.

BERZAGHI, P.; COZZI, G.; ANDRIGHETTO, I. The use of near infrared analysis for in situ studies. Journal of Dairy Science, v.80, p. 3263-3270, 1997. 
BOLSEN, K.K.; LIN, C.; BRENT, B.E.; FEYERHERM, A.M.; AIMUTIS, W.R.; URBAN, J.E. Effect of silage additives on the microbial succession and fermentation process of alfalfa and corn silages. Journal of Dairy Science, v. 75, p.3066-3083, 1992.

BOLSEN, K.K.; ASHBELL, G.; WILKINSON, J.M. Silage additives. In: Biotechnology in animal feeds and animal feeding. ed R.J. Wallace and A. Chesson New York: VCH, 1995. p. 33-54.

BOIN, C.; TEDESCHI, L.O. Cana-de-açúcar na alimentação de gado de corte. In: SIMPÓSIO SOBRE NUTRIÇÃO DE BOVINOS, 5., Piracicaba, 1993. Anais. Piracicaba: FEALQ, 1993. P. 107-126.

BRITT, D.G.; HUBER, J.T.; ROGERS, A.L. Fungal growth and acid production during fermentation and refermentation of organic acid treated corn silages. Journal of Dairy Science, v. 58, p. 532-539, 1975.

CASTRILlÓN, M.V.; SHIMADA, A.S.; CALDERÓN, F.M. Manipulacion de la fermentacion en ensilajes de caña de azucar y su valor alimenticio para borregos. Técnica Pecuária en México, v. 35, p. 48-55, 1978.

CHALUPA, W.; EVANS, J.L.; STILLIONS, M.C. Influence of ethanol on rumen fermentation and nitrogen metabolism. Journal of Animal Science, v. 23, p. 802807, 1964.

COAN, R.M.; SILVEIRA, R.N.; BERNARDES, T.F.; REIS, R.A.; MORENO, T.T.B.; MOREIRA, A.L. Composição química da cana-de-açúcar crua ou queimada ensilada com aditivo (compact disc). In: REUNIÃO DA SOCIEDADE BRASILEIRA DE ZOOTECNIA, 39., Recife, 2002. Anais. Recife: SBZ, 2002. 
COZZOLINO, D.; ACOSTA, Y.; GARCIA, J. Application of near infrared reflectancy espectroscopy (NIRS) to forage evaluation in Uruguay. In: INTERNATIONAL GRASSLANDS CONGRESS, 19., São Pedro, 2001. Proceedings. Piracicaba: FEALQ, 2001. p. 370.

DUBOIS, M.; GILLES, K.A.; HAMILTON, J.K.; REBERS, P.A.; SMITH, F. Colorimetric method for determination of sugars and related substances. Analytical Chemistry, v. 28, p. 350, 1956.

DRIEHUIS, F.; ELFERINK, S.J.W.H.O.; SPOELSTRA, S.F. Anaerobic lactic acid degradation during ensilage of whole crop maize inoculated with Lactobacillus buchneri inhibits yeast growth and improves aerobic stability. Journal of Applied Microbiology, v. 87, p. 583-594, 1999.

DRIEHUIS, F.; WIKSELAAR, P.G. The occurrence and prevention of ethanol fermentation in high-dry-matter grass silage. Journal of Science of Food and Agriculture. v.80, p. 711-718, 2000.

DRIEHUIS, F.; ELFERINK, S.J.W.O.; WIKSELAAR, P.G. Fermentation characteristics and aerobic stability of grass silage inoculated with Lactobacillus buchneri alone and in mixture wi Pediococcus pentosaceus and Lactobacillus plantarum. Grasland Farming - Balancing environmental na economic demands. In: GENERAL MEETING OF THE EUROPEAN GRASSLAND FEDERATION, 18., Tjele, Aalborg 2000. Anais. Aalborg: Danish Institute of agricultural Science, 2000. p. $41-43$.

GONZÁLEZ, E.; MAcLEOD, N.A. Spontaneous fermentation of sugar cane. Tropical Animal Production, v. 1, p. 80-84, 1976. 
GUTIERRES, L.E.; AMORIM, H.V.; BASSO, L.C. Inibidores da fermentação alcoólica. STAB , p. 24-30, jul./ago.1991.

HERNANDEZ, M.R. Avaliação de variedades de cana-de-açúcar através de estudos de desempenho e digestibilidade aparente com bovinos. Jaboticabal, 1998. 78 p. Dissertação (Mestrado) - Faculdade de Ciências Agrárias e Veterinárias de Jaboticabal, Universidade Estadual Paulista “Júlio de Mesquita Filho".

HIGGINBOTHAM, G.E.; MUELLER, S.C.; BOLSEN, K.K.; DePETERS, E.J. Effects of inoculants containing propionic acid bacteria on fermentation and aerobic stability of corn silage. Journal of Dairy Science, v. 81, p. 2185-2192, 1998.

JOHNSON, R.R.; BALWANI, T.L.; JOHNSON, L.J.; McCLURE, K.E.; DEHORITY, B.A. Corn plant maturity. II. Effect on in vitro cellulose digestibility and soluble carbohydrate content. Journal of Animal Science, v. 25, p. 617-623, 1966.

KRISHNAMOORTHY, U.C.; MUSCATO, T.V.; SNIFFEN, C.J.; VAN SOEST, P.J. Nitrogen fractions in selected feedstuffs. Journal of Dairy Science, v. 65, p. 217, 1982.

KUNG Junior, L.; STANLEY, R.W. Effect of stage of naturity on the nutritive value of whole-plant sugarcane preserved as silage. Journal of Animal Science, v. 54, p. 689-696, 1982.

KUNG Junior, L. Preparation of silage water extracts for chemical analyses. Standard operating procedure - 001 6.03.96. ed. University of Delaware - Ruminant Nutrition Lab. - Worrilow 309. 1996. 
KUNG Junior, L.; SHEPERD, A.C.; SMAGALA, A.M.; ENDRES, K.M.; BESSET, C.A; RANJIT, N.K.; GLANCEY, J.L. The effect of preservatives based on propionic acid on the fermentation and aerobic stability of corn silage and a total mixed ration. Journal of Dairy Science, v. 81, p. 1322-1330, 1998.

KUNG Junior, L; ROBINSON, J.R.; RANJT, N.K.; CHEN, J.H.; GOLD, C.M.; PESEK, J.D. Microbial populations, fermentation end-products, and aerobic stability of corn silage treated with ammonia or a propionic acid-based preservative. Journal of Dairy Science, v. 83, p. 1479-1486, 2000.

LAMBERT, R.J.; STRATFORD, M. Weak-acid preservatives: modelling microbial inhibition and response. Journal of Applied Microbiology, v. 86, p. 157-164, 1999.

LÄTTEMÄE, P.; LINGVALL, P. Effect of hexamine and sodium nitrite in combination with sodium benzoate and sodium propionate on fermentation and storage stability of wilted and long cut grass silage. Swedish Journal of Agricultural Research. v.26, p. 135-146, 1996.

LIMA, M.L.M.; MATTOS, W.R.S. Cana-de-açúcar na alimentação de bovinos leiteiros. In: SIMPÓSIO SOBRE NUTRIÇÃO DE BOVINOS. 5., Piracicaba, 1993. Anais. Piracicaba: FEALQ,1993. p.77-105.

LIMA, J.A.; EVANGELISTA, A.R.; ABREU, J.G.; SIQUEIRA, G.R.; SANTANA, R.A.V. Silagem de cana-de-açúcar (Saccharum officinarum L.) enriquecida com uréia ou farelo de soja (compact disc). In: REUNIÃO DA SOCIEDADE BRASILEIRA DE ZOOTECNIA, 39. Recife, 2002. Anais. Recife : SBZ, 2002. 
LIN, C.; BOLSEN, K.K.; HART, R.A.; DICKERSON, J.T.; FEYERHERM, A.M.; AIMUTIS, W.R. Epiphytic microflora on alfalfa and whole-plant corn. Journal of Dairy Science, v. 75, p. 2484-2493, 1992.

LÓPEZ, J.M.; PRESTON, T.R. Rock phosphate, ammonium sulphate and ammonium hydroxide as additives in the ensiling of sugar cane. Tropical Animal Production, v. 2, p. 328-333, 1977.

LÓPEZ, Z.A.; MOREÑO, I.E.; FOGLIATA, F.A.; AYALA, H.G. Microbial population of sugar juice that is neither affected nor deteriorated by frost. Sugar y Azúcar, v. 83, p.21-34, set.1988.

MANN, E.M.; McDONALD, P. The effect of formalin and lower volatile fatty acids on silage fermentation. Journal of Science of Food and Agriculture, v. 27, p. 612616, 1976.

MARTIN, E.V. Some aspects of yeast anaerobic metabolism examined by inhibition of pyruvate decarboxylase. Journal of Chemical Education, v. 75, p. 1281-1283, 1998.

MATSUOKA, S.; HOFFMANN, H.P. Variedades de cana-de-açúcar para bovinos. In : SIMPÓSIO SOBRE NUTRIÇÃO DE BOVINOS. 5., Piracicaba, 1993. Anais. Piracicaba: FEALQ, 1993. p. 17-35.

MATTOS, W.R.S. Utilização de bagaço de cana-de-açúcar na alimentação de ruminantes. In: Utilização de resíduos agro-industriais da cana-de-açúcar na alimentação de ruminantes. Piracicaba. FEALQ, 1985, 72 p.

McDONALD, P.; HENDERSON, A.R.; HERON, S.J.E. The biochemistry of silage. 2 ed. Marlow: Chalcomb Publ., 1991. 340 p. 
MOLINA, L.R.; FERREIRA, D.A.; GONÇALVES, L.C.; CASTRO NETO, A.G.; RODRIGUES, N.M. Padrão de fermentação da silagem de cana-de-açúcar (Saccharum officinarum L.) submetida a diferentes tratamentos (compact disc). In: REUNIÃO DA SOCIEDADE BRASILEIRA DE ZOOTECNIA, 39., Recife, 2002. Anais. Recife : SBZ, 2002.

MOON, N.J. Inhibition of the growth of acid tolerant yeasts by acetate, lactate and propionate and their synergistic mixtures. Journal of Applied Bacteriology, v. 55, p. $453-460,1983$.

MUCK, R.E. The role of silage additives in making high quality silage. In: NATIONAL SILAGE PRODUCERS CONFERENCE, Ithaca, 1993. Proceedings Ithaca: Northeast Regional Agricultural Engineering Service, 1993. p.106-116.

NATIONAL RESEARCH COUNCIL. Nutrient requirements of dairy cattle. 7.ed. Washington: National Academy Press, 2001. 381p.

OHYAMA, Y.; MASAKI, S.; HARA, S. Factors influencing aerobic deterioration of silages and changes in chemical composition after opening silos. Journal of Science of Food and Agriculture. v.26, p. 1137-1147, 1975.

PEDROSO, A.F.; NUSSIO, L.G.; PAZIANI, S.F; LOURES, D.R.S.; IGARASI, M.S.; MARI, L.J; COElHO, R.M; RIBEIRO, J.L.; ZOPOLLATTO, M.; HORII, J. Bacterial inoculants and chemical additives to improve fermentation in sugar cane (Saccharum officinarum) silage. In: INTERNATIONAL SILAGE CONFERENCE, 13. Auchincruive 2002. Anais. Auchincruive: SAC, 2002. p- 66.

PRESTON, T.R.; HINOJOSA, C.; MARTINEZ, L. Ensiling of sugar cane with ammonia molasses and mineral acids. Tropical Animal Production, v. 1, p. 120126, 1976. 
RANJIT, N.K.; KUNG JR., L. The effect of Lactobacillus buchneri, Lactobacillus plantarum, or a chemical preservative on the fermentation and aerobic stability of corn silage. Journal of Dairy Science, v. 83, p.526-535, 2000.

RANJIT, N.K.; TAYLOR, C.C.; KUNG JR., L. Effect of Lactobacillus buchneri 40788 on the fermentation, aerobic stability and nutritive value of maize silage. Grass and Forage Science, v. 57, p. 73-81, 2002.

RODRIGUES, A.A.; CRUZ, GERALDEO M.C.; BATISTA, L.A.R.; LANDELL, M. G.A.; Qualidade de dezoito variedades de cana-de-açúcar como alimento para bovinos. In: REUNIÃO DA SOCIEDADE BRASILEIRA DE ZOOTECNIA, 38., Piracicaba, 2001. Anais. Piracicaba: SBZ, 2001. p. 1111-1112.

ROTZ, C.A.; MUCK, R.E. Changes in forage quality during harvest and storage. In: Forage quality, evaluation and utilization. Madison: ASA; CSSA; SSSA, 1994. p.828-868.

SAS INSTITUTE. SAS/STAT user's guide. Cary, 1988.

SEALE, D.R.; PAHLOW, G.; SPOELSTRA, S.F.; LINDGREN, S.; DELLAGLIO, F., LOWE, J.F. Methods for the microbiological analysis of silages. In. EUROBAC CONFERENCE. Uppsala, 1986. Proceedings. Uppsala: Swed. Univ. Agric. Sci., 1986. p. 147.

SHENK, J.S.; WESTERHAUS, M.O. Population definition, sample selection, and calibration procedures for near infrared reflectancy spectroscopy. Crop Science, v.31, p. 469-474, 1991.

SILVA, D.J. Análise de alimentos (Métodos químicos e biológicos). Viçosa: UFV, 1981. 165p. 
SILVA, S.A.R. Avaliação da eficiência fermentativa da cana-de-açúcar ensilada com diferentes aditivos. Goiânia, 2003. 44p. Dissertação (Mestrado) - Escola de Veterinária, Universidade Federal de Goiás.

SILVA, S.C. A cana-de-açúcar como alimento volumoso suplementar. In: Volumosos para bovinos. FEALQ, 1993. p. 59-74.

SILVESTRE, R.; McLEOD, N.A; PRESTON, T.R. The performance of steers fed fresh chopped whole sugarcane or after ensiling with urea or ammonia. Tropical Animal Production, v. 1, p. 40, 1976.

TAYLOR, C.C.; KUNG Jr, L. The effect of Lactobacillus buchneri 40788 on the fermentation and aerobic stability of high moisture corn in laboratory silos. Journal of Dairy Science, v. 85, p. 1526-1532, 2002.

TAYLOR, C.C.; RANJIT, N.J.; MILLS, J.A.; NEYLON, J.M.; KUNG JR, L. The effect of treating whole-plant barley with Lactobacillus buchneri 40788 on silage fermentation, aerobic stability, and nutritive value for dairy cows. Journal of Dairy Science. v. 85, p. 1793-1800, 2002.

UNDERSANDER, D.; MERTENS, D.R.; THIEX, N. Forage analyses procedures. Omaha: National Forage Testing Association, 1993.

VALVASORI, E.; LUCCI, C.S.; PIRES, F.L.; ARCARO, J.R.P.; ARCARO JR., I. Desempenho de bezerros recebendo silagens de sorgo ou de cana-de-açúcar como únicos alimentos volumosos. Brazilian Journal of Veterinary Research and Animal Science.

http://www.scielo.br/scielo.php...5961998000500009\&Ing=em\&nrm=isc (15 dez. 2002) 
VAN SOEST, P.J.; ROBERTSON, J.B. Analysis of forages and fibrous foods. Ithaca: Cornell University, 1985. 202 p.

VAN SOEST, P.J. Nutritional ecology of the ruminant. 2. ed. Ithaca: Cornell University Press, 1994. 476 p.

WEINBERG, Z.G.; ASHBELL, G.; HOREY, B. The effect of sorbic acid on loss reduction during storage of orange peels. Journal of Science of Food and Agriculture, v. 46, p. 253-258, 1989.

WOOLFORD, M.K. Microbial screening of food preservatives, cold sterilants and specific antimicrobial agents as potencial silage additives. Journal of Science of Food and Agriculture, v. 26, p.229-237, 1975.

WILSON, R.K. A rapid accurate method for measuring volatile fatty acids and lactic acid in silage. Ruakura: Animal Research Institute, 1971. p. 6-12. 